Review

\title{
A Critical Overview of the State-of-the-Art Methods for Biogas Purification and Utilization Processes
}

\author{
Muhamed Rasit Atelge ${ }^{1, *}$ (C), Halil Senol ${ }^{2}$, Mohammed Djaafri ${ }^{3}$, Tulin Avci Hansu ${ }^{4}$, David Krisa ${ }^{5}$, \\ Abdulaziz Atabani ${ }^{6, *}{ }^{\circ}$, Cigdem Eskicioglu ${ }^{5}$, Hamdi Muratçobanoğlu ${ }^{7}{ }^{\circ}$, Sebahattin Unalan ${ }^{6}$, \\ Slimane Kalloum ${ }^{8}$, Nuri Azbar ${ }^{9}$ and Hilal Demir Kıvrak ${ }^{10}$
}

check for updates

Citation: Atelge, M.R.; Senol, H.; Djaafri, M.; Hansu, T.A.; Krisa, D.; Atabani, A.; Eskicioglu, C.; Muratçobanoğlu, H.; Unalan, S.; Kalloum, S.; et al. A Critical Overview of the State-of-the-Art Methods for Biogas Purification and Utilization Processes. Sustainability 2021, 13, 11515. https://doi.org/ $10.3390 /$ su132011515

Academic Editor: Idiano D’Adamo

Received: 10 September 2021

Accepted: 11 October 2021

Published: 18 October 2021

Publisher's Note: MDPI stays neutral with regard to jurisdictional claims in published maps and institutional affiliations.

Copyright: (c) 2021 by the authors. Licensee MDPI, Basel, Switzerland. This article is an open access article distributed under the terms and conditions of the Creative Commons Attribution (CC BY) license (https:// creativecommons.org/licenses/by/ $4.0 /)$.
1 Department of Mechanical Engineering, Faculty of Engineering, Siirt University, Siirt 56100, Turkey

2 Department of Electrical and Electronics Engineering, Giresun University, Giresun 28200, Turkey; halilsenol@yahoo.com

3 Unité de Recherche en Energie Renouvelables en Milieu Saharien (URERMS), Centre de Développement des Energies Renouvelables (CDER), Adrar 01000, Algeria; djaafrimoh@yahoo.fr

4 Department of Chemical Engineering, Faculty of Engineering, Siirt University, Siirt 56100, Turkey; tulin.hansu@siirt.edu.tr

5 UBC Bioreactor Technology Group, School of Engineering, Okanagan Campus, The University of British Columbia, 3333 University Way, Kelowna, BC V1V 1V7, Canada; david.krisa@gmail.com (D.K.); cigdem.eskicioglu@ubc.ca (C.E.)

6 Alternative Fuels Research Laboratory (AFRL), Energy Division, Department of Mechanical Engineering, Faculty of Engineering, Erciyes University, Kayseri 38039, Turkey; sebahattinunalan@gmail.com

7 Department of Environmental Engineering, Faculty of Engineering, Niğde Ömer Halisdemir University, Niğde 51240, Turkey; hamdimuratcobanoglu@gmail.com

8 Laboratory of Energy, Environment and Information System, Adrar University, Adrar 01000, Algeria; kalloum_sli@yahoo.fr

9 Bioengineering Department, Faculty of Engineering, Ege University, Bornova, Izmir 35100, Turkey; nuri.azbar@ege.edu.tr

10 Department of Chemical Engineering, Faculty of Engineering and Architectural Sciences, Eskisehir Osmangazi University, Eskisehir 26040, Turkey; hilaldemir.kivrak@ogu.edu.tr

* Correspondence: rasitatelge@gmail.com (M.R.A.); aeatabani@gmail.com or a.atabani@erciyes.edu.tr (A.A.)

Abstract: Biogas is one of the most attractive renewable resources due to its ability to convert waste into energy. Biogas is produced during an anaerobic digestion process from different organic waste resources with a combination of mainly $\mathrm{CH}_{4}(\sim 50 \mathrm{~mol} / \mathrm{mol}), \mathrm{CO}_{2}(\sim 15 \mathrm{~mol} / \mathrm{mol})$, and some trace gasses. The percentage of these trace gases is related to operating conditions and feedstocks. Due to the impurities of the trace gases, raw biogas has to be cleaned before use for many applications. Therefore, the cleaning, upgrading, and utilization of biogas has become an important topic that has been widely studied in recent years. In this review, raw biogas components are investigated in relation to feedstock resources. Then, using recent developments, it describes the cleaning methods that have been used to eliminate unwanted components in biogas. Additionally, the upgrading processes are systematically reviewed according to their technology, recovery range, and state of the art methods in this area, regarding obtaining biomethane from biogas. Furthermore, these upgrading methods have been comprehensively reviewed and compared with each other in terms of electricity consumption and methane losses. This comparison revealed that amine scrubbing is one the most promising methods in terms of methane losses and the energy demand of the system. In the section on biogas utilization, raw biogas and biomethane have been assessed with recently available data from the literature according to their usage areas and methods. It seems that biogas can be used as a biofuel to produce energy via CHP and fuel cells with high efficiency. Moreover, it is able to be utilized in an internal combustion engine which reduces exhaust emissions by using biofuels. Lastly, chemical production such as biomethanol, bioethanol, and higher alcohols are in the development stage for utilization of biogas and are discussed in depth. This review reveals that most biogas utilization approaches are in their early stages. The gaps that require further investigations in the field have been identified and highlighted for future research.

Keywords: biofuels; biogas components; purification; utilization of biogas 


\section{Introduction}

The bioeconomy is a new approach economy model that produces energy, food, and materials from renewable biological resources [1]. Bioenergy, which is produced from biomass, may be used in any energy industry, such as electricity and transport. The circular bioeconomy has become more competitive with conventional production pathways every day. The productivity of resources, especially bioenergy, has been shown to affect economic growth [2]. As a result, it is clear that the expansion of the bioenergy business aids the reduction in pollution and unemployment [3]. Several authors have concluded that bioenergy has a significant role to play in the decarbonization of society. In this context, it is critical to widen and deepen investigations of bioenergy materials that could be employed to aid in the attainment of sustainability objectives [4]. D'Adamo et al. [1] has explained and highlighted very well the future trend of renewable energy resources and especially their sustainability aspect with new concepts definitions. Renewable energies are critical components of the energy revolution, which aims to replace fossil fuel production with renewable energy [1]. Biomasses, when compared to other green sources such as wind, photovoltaic, and hydropower, can have the greatest influence in this context. Biomasses are suitable for use in local energy supply and consumption systems. This means that energy production from locally sourced biomass is far more sustainable than energy production from biomass sourced from other areas, sometimes even across national borders [1]. This practice must be closely monitored, and it must be accompanied by sustainability evaluations that justify its use. The goal is to promote the use of renewable energy sources in order to achieve circularity while maintaining an appropriate tradeoff between food production and biobased energy resource generation [1]. It is important to remember that the existing transportation industry generates a substantial amount of global emissions, and the percentage of renewable energy in this sector has not yet reached acceptable levels [1]. Among the renewable energy production pathways, biogas produced through the anaerobic digestion process is under the spotlight due to being able to answer those concerns mentioned above.

Anaerobic digestion is a series of successive biochemical reactions, namely hydrolysis, acidogenesis, acetogenesis, and methanogenesis, performed under strict anaerobic conditions [5-7]. These reactions lead to a gas mixture production known as digestion gas or biogas. The primary gas of economic value among these components is methane. For this reason, the term "biogas" is an inaccurate and imprecise term, because the carbon dioxide $\left(\mathrm{CO}_{2}\right)$ gas produced by aerobic decomposition is also "biogas" in a sense-just like other biogasses, it is the result of the biodegradation. However, the term "biogas" is specifically used to refer to the $\mathrm{CH}_{4}-\mathrm{CO}_{2}$ combustible mixture produced by the anaerobic decomposition of organic matter [8]. This biogas is made up of $45-75 \%$ methane $\left(\mathrm{CH}_{4}\right)$, the remainder being mainly $\mathrm{CO}_{2}$ between $20-55 \%$, with traces of other gaseous compounds (impurities) such as hydrogen sulfide $\left(\mathrm{H}_{2} \mathrm{~S}\right)$, nitrogen $\left(\mathrm{N}_{2}\right)$, hydrogen $\left(\mathrm{H}_{2}\right)$, oxygen $\left(\mathrm{O}_{2}\right)$, and others, which are explained further in detail below. This biogas becomes flammable at methane levels greater than $45 \%$ [9-11].

Impurities appear for various reasons in raw biogas. Among them, it was found that the feedstock that is introduced into the reactor contains some impurities; these were later found in the generated biogas after the evaporation of impurities in the digester. Siloxanes are an example of such compounds. Similarly, during anaerobic digestion, impurities can likewise be formed. Ammonia and hydrogen are an example of such impurities. Additionally, the temperature inside the reactor and the volatility of the compound influence the quantity that evaporates. In raw biogas, water is also found [12,13]. A good number of these impurities are malodorous, among them, there are $\mathrm{H}_{2} \mathrm{~S}, \mathrm{HCl}, \mathrm{HF}, \mathrm{H}_{2}, \mathrm{CO}$, $\mathrm{O}_{2}, \mathrm{~N}_{2}, \mathrm{NH}_{3}$, and volatile organic compounds (VOCs). They are divided into organic and inorganic compounds. Organic compounds, in addition to containing methane, also include VOCs like siloxanes, iodomethane, toluene, xylenes, ethers, benzene, ketones, naphthalene, alcohols, esters, furans, and undecane. These VOCs also contain nitrogen compounds (due to degradation of protein waste), volatile fatty acids (VFAs), and volatile 
sulfur compounds (VSC). Inorganic gases produced in the anaerobic digester by anoxic respiration (denitrification) are nitrous oxide $\left(\mathrm{N}_{2} \mathrm{O}\right)$ and molecular nitrogen $\left(\mathrm{N}_{2}\right)$. It is also possible to produce these inorganic gases by adding some compounds to increase the alkalinity of digestion, which contain nitrates such as sodium nitrate $\left(\mathrm{NaNO}_{3}\right)$ or by nonoxidative respiration during the transfer of sludge to the digester with the transfer of nitrate ions $\left(\mathrm{NO}_{3}{ }^{-}\right)$. Among the inorganic and the most undesirable gases, which may lead to damage to the digester equipment and are produced during anaerobic digestion, include hydrogen sulfide $\left(\mathrm{H}_{2} \mathrm{~S}\right)$ along with dichlorine monoxide $\left(\mathrm{Cl}_{2} \mathrm{O}\right)$, chlorine $\left(\mathrm{Cl}_{2}\right)$, chloric acid $\left(\mathrm{HClO}_{3}\right)$, and hypochlorous acid $(\mathrm{HClO})$. The production of $\mathrm{H}_{2} \mathrm{~S}$ is due to the proteinaceous compounds containing sulfur that are transferred to the digester with the organic waste feed $[6,14,15]$.

Depending on the subsequent use of the biogas, these impurities linked to the trace compounds must be removed. For example, some applications do not need high-quality energy, such as cooking and lighting and biofuel as biomethane for transportation. In such cases, carbon dioxide removal from biogas (upgrading) becomes unnecessary [16]. However, carbon dioxide removal when using biogas as a vehicle fuel is very necessary. Conversely, the presence of the other impurities in small quantities in the biogas damages equipment, engines, metal parts, etc., as is the case with $\mathrm{H}_{2} \mathrm{~S}$ and water vapor which generate highly corrosive compounds such as $\mathrm{H}_{2} \mathrm{SO}_{4}$, and their presence reduces the equipment's lifespan. Therefore, these impurity types require a deep elimination from biogas before any use $[17,18]$.

Biogas treatment usually aims to be a purifying and upgrading process. The biogas cleaning process (purification) includes firstly drying it by dewatering, then removing hydrogen sulfide, and finally removing other impurities. The upgrading process is precisely the separation of methane from carbon dioxide in the biogas to obtain higher purity methane as a biomethane. [19-21]. There are several methods for purifying and upgrading biogas. Despite its high requirements of energy and chemicals, biological, physical, and chemical methods are the most commonly used. Among these methods, there is chemical or physical adsorption with a high surface area, gas absorption, condensation, washing or scrubbing with specific liquid solvents, catalytic conversion, and membrane separation. Due to the growing demand for energy and chemicals from these technologies, biogas upgrading by biotechnological processes has experienced rapid development in recent years. The biological techniques are considered a promising alternative because of their economic competitiveness and superior environmental sustainability. This technology is based on the use of microbial consortia capable of efficient application even on a small scale. Biofiltration is one of the most important methods used in this field [22,23]. The final product is biomethane typically containing $95-99 \%$ of $\mathrm{CH}_{4}, 1-5 \%$ of $\mathrm{CO}_{2}$, and a significantly low level of $\mathrm{H}_{2} \mathrm{~S}$ [24].

After biogas cleaning and upgrading, natural gas can be replaced by the final biomethane obtained and become a direct alternative when $\mathrm{CH}_{4}>96 \%$, which is the same percentage as natural gas [25]. However, this methane level standard varies from one country to another in the European Union since it is technically a mandatory requirement according to some countries. To illustrate, if the methane content of biogas is higher than $85 \%$, it can be injected into the natural gas grids in the Netherlands, while this percentage must reach $96 \%$ and $97 \%$ in Switzerland and Sweden, respectively [25]. It can be compressed to be used as compressed renewable natural gas (CNG), or else liquefied to be used as liquefied renewable natural gas (LNG) [26]. Biomethane can also be used in a wide range of applications including as fuel for engines and gas turbines to generate electricity, as a conditioner for the storage and preservation of fruits and vegetables, as fuel for fuel cells, as raw materials for modern industry, for disinfection and storage of seeds, and many other uses [27-29].

The global biogas industry market has seen an accelerated increase over the last decade (2009-2019) estimated at more than $126 \%$ as reported by the International Renewable Energy Agency (IRENA). Where the overall potential of the industry has increased from 
46 terawatt hours (TWh) in 2009 to 91.8 TWh in 2019 [30,31]. The European Union produces $69 \%$ of this amount with 63.3 TWh. Germany produces approximately half of the biogas in the entire EU with more than 32.9 TWh followed by Italy and UK with more than 8.2 and 7.5 TWh, respectively. Moreover, there are currently 93 agricultural biogas plants in Poland and their energy production potential is $131 \mathrm{PJ} /$ year [32]. Outside of the European Union, the United States produces 12.6 TWh, China produces 3.8 TWh, Thailand produces 2.6 TWh, and Turkey produces more than 2.5 TWh. The remaining countries outside of the European Union produce less than 2 TWh. The above statistics are for 2019 and were published by IRENA in 2021 [31]. In recent years, the motivation for the choice of biogasupgrading technologies is determined by local markets based on the number of existing biomethane projects [33]. The biomethane sector is mostly developed in the European Union, with Germany holding a strong position due to its decision to utilize biomethane in combined heat and power plants. Sweden, on the other hand, employs biomethane as a biofuel for public transportation [34]. Moreover, a study for biomethane feasibility reveals that when the capacity of biomethane production plants is higher than $500 \mathrm{~m}^{3} / \mathrm{h}$, the plants show significant economic improvements in comparison to small scale plants. Additionally, the economic losses may be between EUR 370,000 and EUR 2.9 million for each year the construction or conversion of biomethane plants is postponed [34]. In the EU, there are 367 operational biomethane plants, and 178 of them which produce 8.5 TWh of biomethane annually, are located in Germany [35]. Moreover, 25 operational biomethane plants are located in the United States, six in Japan, and five in South Korea [35].

The aim of this review is to study biogas in depth, starting with the properties and components of biogas. Moreover, the study investigates impurities in biogas and the possible reasons why they exist in biogas. Afterward, the next section is focused on the elimination of these impurities as a cleaning process with recent developments. In addition, to obtain biomethane from biogas, the upgrading procedures are systematically assessed according to their state of the art technology and recovery range of methane in this area. Furthermore, various upgrading methods have been thoroughly examined and compared in terms of electricity usage of methods and their methane losses. For methane losses and system energy demand, the most promising strategy of the upgrading process was determined. Moreover, raw biogas and biomethane have been assessed with recently available data in the literature in the utilization of the biogas section. Biogas utilization pathways were investigated regarding their electrical production efficiency. Furthermore, the review reveals that biogas can be used as a biofuel for vehicles in an internal combustion engine. The usage of biogas in vehicles as a biofuel was discussed with its advantages and disadvantages. Finally, gaps in the field that needs to be investigated further have been highlighted for future research in this field.

\section{Biogas Properties and Components}

Biogas is produced by organic matter degradation through the anaerobic digestion process using anaerobic digesters or directly from landfills and ponds. The main biogas components are $\mathrm{CH}_{4}$ and $\mathrm{CO}_{2}$. Biogas burns easily due to the presence of methane, while the second noncombustible compound, $\mathrm{CO}_{2}$, lowers the biogas calorific value [16]. However, the biogas becomes flammable as soon as the $\mathrm{CH}_{4}$ content is greater than $45 \%$, and a mixture of $60 \% \mathrm{CH}_{4}$ and $40 \% \mathrm{CO}_{2}$ is capable of keeping a steady flame with a calorific value of approximately $5340 \mathrm{kcal} / \mathrm{m}^{3}$ at $15^{\circ} \mathrm{C}$, compared to $9000 \mathrm{kcal} / \mathrm{m}^{3}$ for pure $\mathrm{CH}_{4}$ [36]. The typical biogas properties are presented in Table 1.

Adding to its two main components $\left(\mathrm{CH}_{4}\right.$ and $\left.\mathrm{CO}_{2}\right)$, raw biogas also contains some impurities in small amounts. These impurities appear because the production and raw biogas composition are affected by several factors including fermentation technology, operating conditions (such as $\mathrm{pH}$, temperature, organic loading rate), substrate type and its organic matter concentration, collection method, etc. [29,37]. Among these impurities there is $\mathrm{H}_{2} \mathrm{~S}(0.005-2 \%), \mathrm{NH}_{3}(<1 \%), \mathrm{N}_{2}(0-2 \%), \mathrm{H}_{2}(0-4 \%), \mathrm{H}_{2} \mathrm{O}(5-10 \%), \mathrm{VOCs}(<0.6 \%)$, $\mathrm{CO}(<0.6 \%)$, siloxanes $(0-0.02 \%)$, and $\mathrm{O}_{2}(0-1 \%)[12,19,21,38,39]$. 
Table 1. The properties of typical biogas from an anaerobic digestion process [40-43].

\begin{tabular}{cc}
\hline Properties & Values \\
\hline Composition & $55-70 \%$ methane $\left(\mathrm{CH}_{4}\right), \begin{array}{c}30-45 \% \text { carbon dioxide }\left(\mathrm{CO}_{2}\right) \text {, traces of } \\
\text { other gases }\end{array}$ \\
\hline Energy content & $6.0-6.5 \mathrm{kWh} / \mathrm{m}^{3}$ \\
\hline Wobble index & $19.5 \mathrm{MJ} / \mathrm{m}^{3}$ \\
\hline Fuel equivalent & $0.60-0.651$ oil $/ \mathrm{m}^{3}$ biogas \\
\hline Explosion limits & $6-12 \%$ biogas in air \\
\hline Ignition temperature & $650-750{ }^{\circ} \mathrm{C}($ with the above-mentioned methane content $)$ \\
\hline Critical pressure & $75-89 \mathrm{bar}$ \\
\hline Critical temperature & $-82.5{ }^{\circ} \mathrm{C}$ \\
\hline Normal density & $1.2 \mathrm{~kg} / \mathrm{m}{ }^{3}$ \\
\hline Heat of vaporization & $0.5 \mathrm{MJ} / \mathrm{kg}$ \\
\hline Smell & Rotten egg (the smell of desulfurized biogas is hardly noticeable) \\
\hline Molar mass & $16.043 \mathrm{~kg} / \mathrm{kmol}$ \\
\hline Methane number & $124-150$ \\
\hline Flame speed & $25 \mathrm{~cm} / \mathrm{s}$ \\
\hline Lower heating value & $17 \mathrm{MJ} / \mathrm{kg}$ \\
\hline
\end{tabular}

The proportion of these impurities in raw biogas is governed by several parameters. Therefore, the percentages differ from one substrate to another and differ within the same substrate if the anaerobic digestion conditions differ. For example, the percentage of $\mathrm{H}_{2} \mathrm{~S}$ in raw biogas varies depending on the percentage of the proteinaceous and other sulfur compounds in the substrate [13]. Additionally, the percentage of $\mathrm{O}_{2}$ and $\mathrm{N}_{2}$ in the raw biogas varies according to the percentage of air introduced into the digester to remove the hydrogen sulfide by oxidation in certain cases, or the air entering the landfill by reducing the gas pressure in order to extract the gas in other cases. There are also other reasons for certain impurities in the the substrate, which can evaporate during the anaerobic digestion process in the reactor due to the process temperature and the component's volatile nature, such as siloxanes and $\mathrm{H}_{2} \mathrm{O}$ found in raw biogas compounds [12,15]. The typical composition of biogas generated from different origins versus natural gas is summarized in Table 2. Hereinafter, each of these impurities will be discussed separately and in depth.

\subsection{Carbon Dioxide}

$\mathrm{CO}_{2}$ is the second main component of biogas. During the complex degradation processes of organic materials, different types of bacteria are involved to produce biogas. $\mathrm{CO}_{2}$ is produced during some of these steps and acts as an electron acceptor for methanogenic microorganisms [13]. The percentage of this component in the biogas is influenced by temperature, pressure, and the liquid content in the digester [42]. The concentration of $\mathrm{CO}_{2}$ dissolved in water decreases with increasing temperature during the fermentation process which causes an increase in the $\mathrm{CO}_{2}$ level in the produced biogas. Unlike the other two parameters (the pressure and the liquid content in the digester), when they are higher, they lead to an increase in the concentration of $\mathrm{CO}_{2}$ dissolved in the water, which causes a decrease in the $\mathrm{CO}_{2}$ level in the produced biogas. This is considered to be beneficial for biogas [42]. 
Table 2. Composition of biogas generated from different origins versus standard biogas (EBA) and natural gas [12,44-46].

\begin{tabular}{|c|c|c|c|c|c|c|}
\hline Compound & Agricultural Waste & Landfills & Industrial Waste & Wastewater & $\begin{array}{c}\text { Standard } \\
\text { Biogas }(\mathrm{EAB} *)\end{array}$ & Natural Gas \\
\hline $\mathrm{CH}_{4} \%$ & $50-80$ & $35-80$ & $50-70$ & $60-70$ & $50-75$ & $81-97$ \\
\hline $\mathrm{CO}_{2} \%$ & $19-50$ & $15-50$ & $30-50$ & $19-40$ & $24-45$ & $0.2-1.5$ \\
\hline $\mathrm{H}_{2} \mathrm{O} \%$ & $\leq 6$ & $1-5$ & $1-5$ & $1-5$ & $1-2$ & - \\
\hline $\mathrm{N}_{2} \%$ & $0-1$ & $0-3$ & $0-3$ & $0-1$ & $1-5$ & $0.28-14$ \\
\hline $\mathrm{O}_{2} \%$ & $0-1$ & $0-1$ & $0-5$ & $<0.5$ & Traces & - \\
\hline $\mathrm{H}_{2} \%$ & $0-2$ & $0-5$ & $0-3$ & 0 & $0-3$ & - \\
\hline $\mathrm{H}_{2} \mathrm{~S}$ ppm & $2160-10,000$ & 0.1 & 0.8 & $0-4,000$ & $0.1-0.5 \%$ & $1.1-5.9$ \\
\hline $\mathrm{NH}_{3} \mathrm{ppm}$ & $50-144$ & $\sim 5$ & - & 100 & - & - \\
\hline $\mathrm{CO} \%$ & $0-1$ & $0-1$ & $0-1$ & - & $0-0.3$ & - \\
\hline Total $\mathrm{Cl} \mathrm{mg} / \mathrm{m}^{3}$ & - & 5 & - & 100 & - & - \\
\hline Siloxanes \% & Traces & Traces & Traces & - & - & - \\
\hline
\end{tabular}

The volumetric energy content of biogas decreases with increasing $\mathrm{CO}_{2}$ percentage. When biogas is used as fuel for vehicles, $\mathrm{CO}_{2}$ is considered an impurity; therefore, it should be removed from raw biogas. However, it can be tolerated for power and heat generation. When $\mathrm{CO}_{2}$ is mixed with water, $\mathrm{CO}_{2}$ will be transformed into carbonic acid. This formation will cause some damage to the equipment [20].

\subsection{Water Vapor}

The anaerobic digestion process is categorized based on humidity in the digester content, which is linked to the moisture content of the feedstock. There are two main anaerobic digestion types: wet (liquid) anaerobic digestion with a moisture content from $85 \%$ to $99.5 \%$ and dry (high solids) anaerobic digestion with humidity from $60 \%$ to $85 \%$ [47]. Accordingly, during the anaerobic digestion process, a small amount of this water evaporates to become one of the biogas components. Its proportion in the biogas is dependent on the internal digester temperature and pressure [20].

The water in raw biogas can create some problems such as corrosion of equipment and reaction with other components like $\mathrm{CO}_{2}, \mathrm{NH}_{3}$, and $\mathrm{H}_{2} \mathrm{~S}$ to produce an acidic solution. Further, it can cause blockage of pipelines, flow meters, valves, compressors, etc., during subsequent cooling. The two phases coexist; liquid and gas cause flow oscillations which can interfere with the operations control. Moreover, water decreases the energy content and affects biogas heat value $[6,13,48,49]$. Briefly, water creates a negative impact on biogas utilization, so it is necessary to dry biogas before use.

\subsection{Hydrogen Sulfide}

Hydrogen sulfide is considered one of the most highly toxic gases as it can lead to serious risks to human health and can kill quickly (from 30 minutes to one hour) if its concentration reaches $0.05 \%$ of inhaled air [50]. It can also be used as a powerful nerve poison. When this gas combines with alkaline substances in tissues, it can form sodium sulfide and cause damage to the respiratory system and eyes. When it arrives in the bloodstream, it associates with hemoglobin which leads to nonreducible hemoglobin formation that causes toxic symptoms. Similarly, it excites human mucous in a strong way. It is quickly taken by the lungs and stomach and can cause conjunctivitis [20,50].

This gas occurs in small amounts (ppm levels) during the protein's degradation throughout the anaerobic digestion process from organically bound sulfur (S-bearing proteins). This gas production rate differs with the protein rate in the substrate entering the digester. Low rates are recorded with vegetable waste. While the highest rate comes 
from protein-rich materials like molasses, which produce more than $3 \%$ by volume of $\mathrm{H}_{2} \mathrm{~S}$. However, the average rates are produced by animal waste such as poultry droppings and cattle and pig manure, with an $\mathrm{H}_{2} \mathrm{~S}$ level of $0.5 \%$ and $0.3 \%$, respectively. Usually, this gas in biogas from wastewater treatment plants is higher compared with biogas from landfills. Another source of $\mathrm{H}_{2} \mathrm{~S}$ gas comes from the biochemical transformation of mineral sulfur (sulfates) to sulfide by sulfate-reducing bacteria. Sulfides are inhibitory to methanogens and can decrease methane production. Another source of $\mathrm{H}_{2} \mathrm{~S}$ gas comes from the biochemical transformation. During the AD process, when the degradation of sulfur (S) compounds and the desulfurization of sulfates $\left(\mathrm{SO}_{4}{ }^{2-}\right)$ occur, $\mathrm{H}_{2} \mathrm{~S}$ is produced. Microorganisms need $\mathrm{SO}_{4}{ }^{2-}$ because it is not only converted into cellular materials with enzymes but also behaves like an electron acceptor while organic matter is oxidized. If $\mathrm{SO}_{4}{ }^{2-}$ exists inside the $\mathrm{AD}$ reactor, $\mathrm{H}_{2} \mathrm{~S}$ is produced from $\mathrm{H}_{2}$ and $\mathrm{SO}_{4}{ }^{2-}$. Sulfate-reducing bacteria and methanogens compete with each other to obtain $\mathrm{H}_{2}$ in the $\mathrm{AD}$ reactor. In this circumstance, sulfate-reducing bacteria can dominate over methanogens due to their higher microbial growth rate, higher demand of $\mathrm{H}_{2}$, and higher energy yield during reduction [50-53]. Therefore, if sulfate is present during anaerobic digestion, the sulfate-reducing bacteria always produce $\mathrm{H}_{2} \mathrm{~S}$.

$\mathrm{H}_{2} \mathrm{~S}$ is the most problematic and common impurity in raw biogas as shown in Table 3 . It is a colorless gas with a strong rotten-egg smell that appears even at very low concentrations ( 0.05 to $500 \mathrm{ppm})$. It is inflammable. When mixed with oxygen, it forms an explosive mixture. On combustion, when it reacts with water it forms sulfur dioxide $\left(\mathrm{SO}_{2}\right)$ which is a toxic material and causes the flue gas to appear corrosive due to the formation of sulfuric acid. The latter causes acid rain to precipitate which is harmful to the environment. The airborne emissions from $\mathrm{SO}_{2}$ are limited in several countries. $\mathrm{H}_{2} \mathrm{~S}$ also produces weak acids when dissolved in water. At room temperature, it can produce metal sulfides by reaction with certain metal oxides such as zinc oxide and ferric oxide. It can also produce hydrosulfide or metal sulfide by reaction with alkalis. Similarly, it can produce low solubility sulfides by reaction with metal ions in liquid form except for alkali metals and ammonium. For copper compounds, this gas type is caustic. Moreover, it also damages many engines components $[13,20,49,50]$.

Table 3. Impurities in biogas and their negatives impacts $[13,21,22,24,25,42,53-58]$.

\begin{tabular}{|c|c|}
\hline Compounds & Negatives Impacts \\
\hline $\mathrm{CO}_{2}$ & $\begin{array}{l}\text { Reduces the overall calorific value; Promotes metal part corrosion due to the formation of low carbonic acid; } \\
\text { Affect and damages alkaline fuel cells; Alteration of combustion properties, which affects the efficiency and } \\
\text { safety of end-user equipment. }\end{array}$ \\
\hline $\mathrm{H}_{2} \mathrm{O}$ & $\begin{array}{l}\text { A major contributor to corrosion in aggregate compressors, gas storage tanks, engines and pipelines by } \\
\text { forming acid with other compounds such as } \mathrm{H}_{2} \mathrm{~S}, \mathrm{NH}_{3} \text {, and } \mathrm{CO}_{2} ; \text { Condensation formation resulting in } \\
\text { damage to instruments; Freezing of accumulated water under high pressure and low-temperature } \\
\text { conditions; Corrosion, rust, lubrication washes, clogging of pipes; Absorption/accumulation of other } \\
\text { contaminants; Reduce combined heat and power production in cogeneration engine efficiency; Damage gas } \\
\text { compressors; Condensation due to high pressure; accumulation in pipes. }\end{array}$ \\
\hline $\mathrm{H}_{2} \mathrm{~S}$ & $\begin{array}{l}\text { Acts as a corrosive in pipelines; Causes } \mathrm{SO}_{2} \text { emissions after combustion or } \mathrm{H}_{2} \mathrm{~S} \text { emissions in case of } \\
\text { incomplete combustion. } \\
\text { Poisons catalytic converter; Corrosive to steel reactors, compressors, gas storage tanks, engines and } \\
\text { instruments; Toxic at } 450 \mathrm{ppm} \text { or }\left(>5 \mathrm{~mL} / \mathrm{m}^{3}\right) \text {; Due to furious combustion, there is the formation of } \mathrm{SO}_{2}, \mathrm{SO}_{3} \text {, } \\
\text { which is more highly toxic than } \mathrm{H}_{2} \mathrm{~S} \text { and can form } \mathrm{H}_{2} \mathrm{SO}_{4} \text { causing more severe corrosion; Adsorbs } \\
\text { irreversibly on the adsorbent and poisons it; Poison of the catalytic converter; Inhibits adsorption of fuel } \\
\text { molecules and thus affects fuel oxidation; Affects fuel reforming, causes resistance to mass transport across } \\
\text { electrodes caused by sulfur blocking sites; Unpleasant odor; Toxic to PSA adsorbents. }\end{array}$ \\
\hline Siloxanes & $\begin{array}{l}\text { Formation of } \mathrm{SiO}_{2} \text { and microcrystalline quartz during the combustion process and deposition on engine } \\
\text { surfaces, valves, spark plugs, and cylinder heads, abrading the surface and causing grinding and } \\
\text { malfunctioning of the engine part; Abrasion of engines, insulators, and spark plugs. }\end{array}$ \\
\hline
\end{tabular}


Table 3. Cont.

\begin{tabular}{cc}
\hline Compounds & Negatives Impacts \\
\hline $\mathrm{NH}_{3}, \mathrm{O}_{2}$ & $\begin{array}{r}\mathrm{NH}_{3} \text { : Toxic to anaerobic bacteria; Leads to an increase in the anti-knock properties of engines; Increased NOx } \\
\text { emissions after combustion; Toxic compound: health problems; Corrosion in equipment due to reaction with } \\
\mathrm{H}_{2} \mathrm{O} \text { to form a base; Forms nitrogen oxides during combustion in gas engines, foul odor. } \\
\mathrm{O}_{2} \text { : Explosive at high } \mathrm{O}_{2} \text { concentration in biogas. }\end{array}$ \\
\hline VOCs & $\begin{array}{r}\text { Toxic, and forms polyhalogenated dioxins and furans; Corrosive to combustion engines; Effect on elastomers } \\
\text { and plastics: system integrity problems; Carcinogenic and toxic: health problems; Soot formation during the } \\
\text { combustion of PAHs; Impact on safety and performance of end-user equipment. }\end{array}$ \\
\hline Particulates (dust) & Damages vents and exhaust by clogging; Clogging equipment and engine because of deposition in \\
compressors and gas storage tanks.
\end{tabular}

\subsection{Siloxanes}

Siloxanes are organic compounds based on a combination and repitition of silicon and oxygen atoms encircled by methyl groups. Usually they are classified as VOCs because they are degraded into volatile methyl siloxanes (VMS). The latter have a linear or cyclic structure and their degradation makes them a low molecular-weight species $[42,59,60]$.

Siloxanes are mostly added to health care consumer products to improve lubricity. They are used in a wide range of products including cosmetics, shampoos, soaps, detergents, in industrial uses as precursors in polymeric silicone products, paints, etc. [59-61]. Most of these compounds are drained to wastewater treatment plants (WWTP) after rinsing, where they are absorbed by sludge. Since these siloxanes are resistant to biological and chemical degradation and have low solubility, they accumulate inside the sludge, making it a reservoir of siloxanes. Another reservoir for siloxanes is landfill, where most of the residues of the product containing siloxanes are disposed of $[57,59,61]$.

While treating sludge by an anaerobic digestion process or waste in landfills, the siloxanes are present in the raw biogas as impurities. Therefore, it is expected that the amount of the siloxanes in the biogas produced from digesters that use food waste, agricultural product residues, or animal manure are much less than those produced by landfills or digesters treating sludge. Previous studies showed that the maximum amount of siloxanes expected to be found in biogas produced from landfills is from 4 to 9 ppm, while this percentage exceeds $41 \mathrm{ppm}$ in biogas from digesters treating sludge $[27,53]$.

As mentioned above, the siloxanes present in raw biogas are problematic impurities. As this affects the biogas performance as an energy source, it also affects the equipment used during energy production. Whereas during the biogas combustion process, oxygen reacts with the VMS under high temperature and pressure, the white $\mathrm{SiO}_{2}$ deposits are formed in different morphological forms (white, glassy, crystal, microcrystalline, and amorphous deposits) [62,63]. In some cases, these deposits are associated with other components like calcium or sulfur [64]. These deposits can generate abrasive and thermal insulating properties, that can cause damage to turbines, reduce engine life and efficiency, and cause damage to their accessories such as valves, engine heads, and spark plugs. Additionally, these deposits may cause explosions in the combustion chambers, poisoning of catalysts, and may blocks pipes. For that, in raw biogas, the recommended siloxanes limit is $0.2 \mathrm{mg} \mathrm{m}^{-3}$, and in some industries, the strict rule is $<0.1 \mathrm{mg} / \mathrm{m}^{3}[42,57,59,65]$.

\subsection{Nitrogen, Ammonia Nitrogen, and Oxygen}

Nitrogen and oxygen are generally absent in the reactor because of anaerobic conditions. If nitrogen is detected in raw biogas, it is a strong sign of denitrification or air leakage in the reactor. Additionally, among the existing causes of nitrogen compounds in biogas, the main cause is the release of nitrogen compounds after the bacterial reduction of proteins in the reducing medium which are subsequently transformed into ammonia [20,49]. Biogas produced from organic or agricultural waste digesters generally contains a low nitrogen proportion (usually $0.1 \%$ ) compared to that produced from landfills (mostly from $5 \%$ to 
15\%) [66]. On the contrary, aqueous ammonia could be used for biogas purification and upgrading by absorbing $\mathrm{H}_{2} \mathrm{~S}$ and $\mathrm{CO}_{2}$ [67]. A recent study demonstrates a significant positive effect of ammonia nitrogen on biogas upgrading. With $5500 \mathrm{mg} / \mathrm{L}$ of ammonia nitrogen, the $\mathrm{CH}_{4}$ content in biogas reached 94.1\% [68].

A small amount of oxygen is found in raw biogas produced from anaerobic digestion, because oxygen will react with $\mathrm{H}_{2} \mathrm{~S}$ or be consumed by facultative anaerobic bacteria at the start of the anaerobic digestion process, and oxygen itself will not be detected. Similarly, landfill gas extraction leads to low internal pressure, which causes some air absorption [20,42,69]. The oxygen could cause an explosion if the $\mathrm{CH}_{4}$ content is $60 \%$ in biogas and the air reaches a range between $8.5 \%$ and $20.7 \%$ at $25{ }^{\circ} \mathrm{C}$ [42]. Additionally, oxygen can lead to flammable mixture formation [20]. Therefore, the ratio of air should be carefully adjusted. An oxygen amount of $1 \%$ to $2 \%$ is cited as ideal [70]. Likewise, a $4: 1$ nitrogen to oxygen ratio in raw biogas is mentioned as ideal [8].

\subsection{Volatile Organic Compounds}

Volatile organic compounds (VOCs) exist in trace amounts in biogas. They are divided into different chemical families such as aromatics, alkanes, alcohols, halogens, sulfur compounds (excluding hydrogen sulfide), carbonyls, and siloxanes $[9,53]$. These compounds' type and concentrations in biogas depend on the substrate's origin. For example, a very low concentration of these compounds was recorded in farm digester biogas. On the contrary, this concentration increased in the gases produced by wastewater, household waste, and landfills [71]. Materials that produce these components include cleaning compounds, cosmetic products, silicon compounds, lacquers, foaming agents, pharmaceuticals, aggregates, adhesives, solvents, pesticides, synthetic plastics, propellants, textiles, coatings, etc. [66,72] The concentration increase of these compounds in biogas is attributed to direct emission from the substrate or to the volatilization after the compounds' degradation (complex molecules) and their transformation into low molecular mass. Consequently, the VOCs measured in biogas at the start of digestion come essentially from direct volatilization, while the concentration of those measured after a certain duration of digestion in biogas are dictated by the substrate biodegradation rate [9].

Despite their low concentration in raw biogas (usually $1 \%$ by volume), just like hydrogen sulfide, VOCs lead to equipment problems and negative environmental effects such as greenhouse gases, groundwater contaminants, and disagreeable odor, and they can affect human health $[9,73]$. For example, acids can be formed during halogenated hydrocarbons combustion (in the presence of water) such as hydrofluoric acid (HF) or hydrochloric acid $(\mathrm{HCl})$ which can cause acidification, premature equipment degradation, and corrosion of materials and catalytic surfaces $[20,72]$. Similarly, organochloride in biogas can lead to combustion-engine corrosion, and silicon and chloride compounds make landfill gas as vehicle fuel much more expensive and often too complicated [52,66]. Generally, VOC accumulation affects the proper functioning of systems for converting biogas into energy; for this reason, their contents in biogas must be carefully controlled.

\subsection{Particulates}

Several researchers have reported the presence of particulates (dust) in raw biogas produced from digestion or landfills. This can lead to mechanical damage to gas turbines and gas engines due to their abrasive properties, or cause blockages when they deposit in the gas storage tank and compressor. They can also form condensation nuclei of water droplets $[6,20,45,74,75]$. For these reasons, the total content of particles and aerosols in the biogas must be maintained under $0.01 \mathrm{mg} / \mathrm{m}^{3}[56,69]$.

\section{Current Biogas Purification Technologies}

In this section, the latest technologies for the improvement and upgrade of biogas and the resulting biological methanation processes are summarized. This paper examines the main principles of various upgrade methods, the technical and scientific fea- 
tures/consequences for biomethanation efficiency, the challenges that need to be addressed for further improvement, and the applicability of upgrade concepts.

As mentioned in the previous section, the ratio of $\mathrm{CH}_{4}$ and $\mathrm{CO}_{2}$ in the biogas is mostly in the range of $50-70 \%$ and $30-50 \%$, respectively, depending partly on the organic content and $\mathrm{pH}$ of the substrate. [19]. In addition to $\mathrm{CH}_{4}$ and $\mathrm{CO}_{2}$ gases, biogas may contain $\mathrm{N}_{2}$ gas in the concentration range of $0-3 \%$ depending on the volume of the head space at the start of gas production in the reactors [76]. The most important minor components are carbon monoxide (CO), $\mathrm{O}_{2}$, hydrogen sulfide, $\mathrm{H}_{2}$, and $\mathrm{NH}_{3}$ [29]. Depending on the substrate source in the reactors, biogas may contain other contaminants such as siloxanes $\left(0-41 \mathrm{mg} \mathrm{Si} / \mathrm{m}^{3}\right)$, volatile hydrocarbons (alcohols, fatty acids, terpenes) or fluorinated hydrocarbons, chlorinated, heavy metal vapors, and aromates [77].

All gases except $\mathrm{CH}_{4}$ contained in biogas are undesirable gases and are known as biogas pollutants. For the biogas purification process, the first step is biogas cleaning and the second step is biogas upgrading. Biogas cleaning is performed to remove harmful or toxic components such as $\mathrm{H}_{2} \mathrm{~S}, \mathrm{Si}, \mathrm{CO}$, siloxanes, VOCs, and $\mathrm{NH}_{3}$ [19]. The second step, biogas upgrading, aims to increase the calorific value of biogas and convert it to a fuel standard. In addition, biogas upgrading is a multistage gas-separation process that involves the separation of $\mathrm{CO}_{2}$ gas, drying the gas to remove moisture content, and extracting and compressing other small components [77]. In order for biogas to be used in different applications, its methane content must be at least $90 \%(v / v)$ [17]. Upgraded biogas that has a $95 \%(v / v)$ methane content is called biomethane [78].

\subsection{Carbon Dioxide Removal}

Almost all of the noncombustible portion of biogas is $\mathrm{CO}_{2}$ gas, and this reduces the calorific value per unit volume of biogas. This limits biogas for uses such as biofuel for transportation, cooking, and lighting, etc., where direct combustion technology is needed. $\mathrm{CO}_{2}$ creates disadvantages such as the extra space occupied in the biogas storage area and the use of extra energy in the compression of the biogas. Dry ice is formed as a result of the compression of biogas with $\mathrm{CO}_{2}$ and this creates the problems of lump formation and freezing in valves or measurement points. This makes it difficult to store biogas in containers for transportation and limits its use. For such reasons, the removal of $\mathrm{CO}_{2}$ in biogas gains importance in terms of its use in larger scales [17].

Various commercial technologies are available to separate $\mathrm{CO}_{2}$ from biogas. The higher solubility of $\mathrm{CO}_{2}$ in water than $\mathrm{CH}_{4}$ gas enables them to be separated from each other by taking advantage of the difference in their solubility in water. At $25{ }^{\circ} \mathrm{C}$, the solubility of $\mathrm{CO}_{2}$ in water is 26 times higher than the water solubility of $\mathrm{CH}_{4}$. Biomethane containing $95-99 \%(v / v) \mathrm{CH}_{4}$ can be obtained as a result of the separation process in this way [21]. Water scrubbing is one of the most common methods used for biogas cleaning [19]. Figure 1 shows a schematic of a process flow diagram of a recirculating water scrubber. Biogas is sent to the absorption column by pressurizing from the bottom (6-10 bar) and water is supplied from the top of the column at the same time. The absorption column used is filled with random packaging material in order to work more effectively [21]. The saturated water is transferred to the flash tank where the pressure is dropped to around three bars to minimalize methane loss. The water leaves the flash tank and goes to the desorption column. Air is taken into the desorption tank due to increasing the driving force for $\mathrm{CO}_{2}$ desorption by decreasing its partial pressure. A $1000 \mathrm{Nm}^{3} / \mathrm{h}$ raw biogas water scrubber upgrading system needs to circulate $200 \mathrm{~m}^{3} / \mathrm{h}$ water at 8 bars of pressure at $20{ }^{\circ} \mathrm{C}$ [79]. The benefit of the water scrubber is that $\mathrm{H}_{2} \mathrm{~S}$ can be eliminated with the removal of $\mathrm{CO}_{2}$ because the solubility of $\mathrm{H}_{2} \mathrm{~S}$ in water is higher than $\mathrm{CO}_{2}$. If the $\mathrm{H}_{2} \mathrm{~S}$ is removed with $\mathrm{CO}_{2}$ at the same time, the water quality can decrease rapidly, therefore, using fresh water is recommended. The upgrading system has some advantages such as being economical, having high efficiency, not requiring additional chemicals, and gaining a high level of methane recovery above $97 \%$ [75]. However, the high initial investment and high energy demand during water regeneration are the primary drawbacks of the system. 


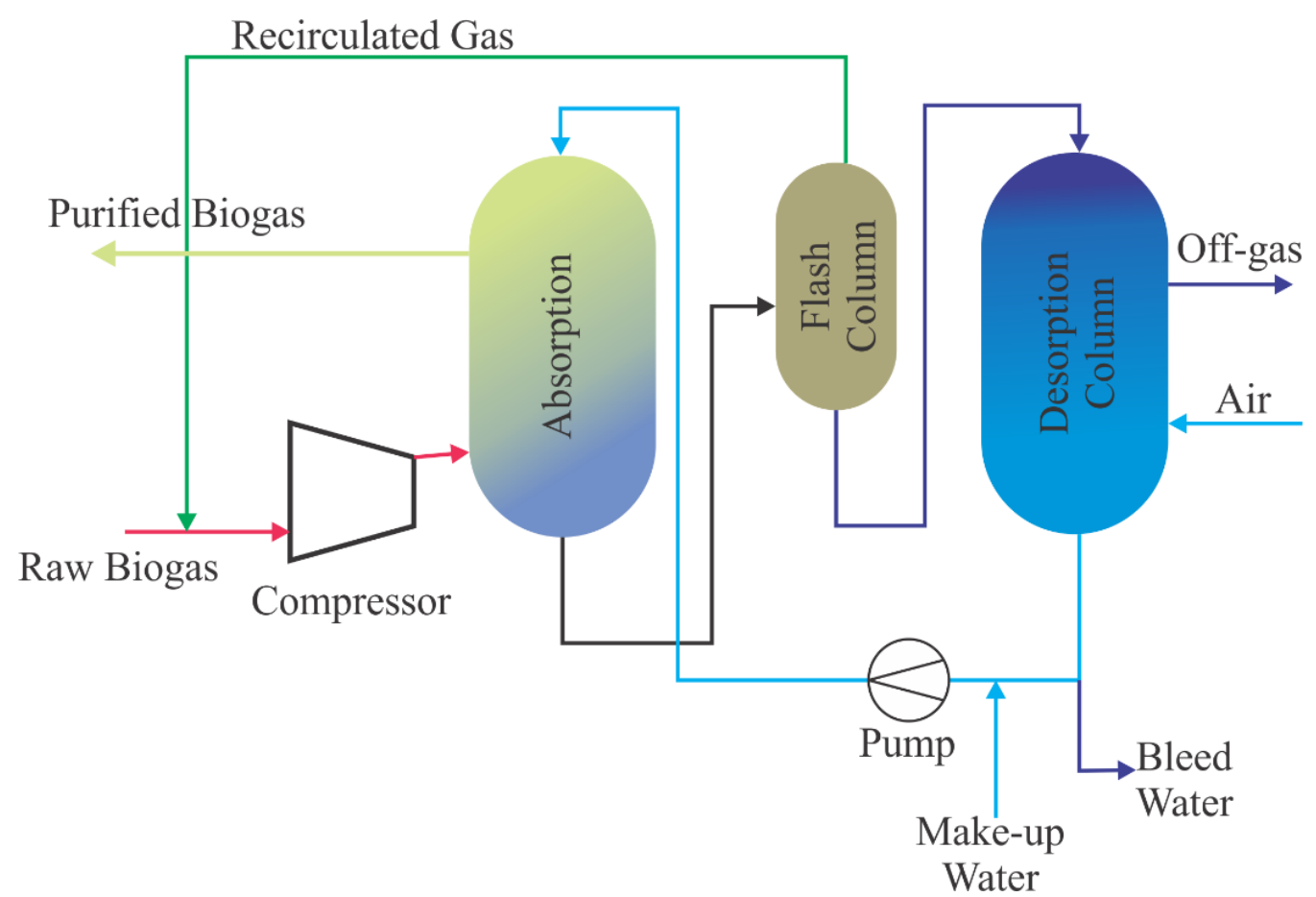

Figure 1. The schematic flow chart of a recirculating water scrubber (adapted from [79]).

By choosing a washing liquid that is more effective than water in the separation of $\mathrm{CO}_{2}$ and $\mathrm{CH}_{4}$ in biogas, further improvement of absorption can be achieved. In this context, the most commonly used chemicals are aqueous solutions of amines such as diethanolamine, methyldiethanolamine, monoethanolamine, and diglycolamine [21]. Such biogas-boosting methods are also called amine scrubbing. Figure 2 shows a schematic of biogas upgrading by amine scrubbing of $\mathrm{CO}_{2}$. The raw biogas enters the absorption tank from the bottom, and amine solvent enters through the top of the tank. During the counter-current flow, $\mathrm{CO}_{2}$ reacts with the amine solvent. During the reaction, the temperature increases from between $20-40{ }^{\circ} \mathrm{C}$ to between $45-65{ }^{\circ} \mathrm{C}$ due to an exothermic reaction [80]. Generally, an increase in the temperature decreases the solubility of materials but the solubility of $\mathrm{CO}_{2}$ in amine solvent increases with an increase in temperature [75]. After the reaction, the liquid goes to the heat exchanger to increase its temperature and is boiled at $120-150^{\circ} \mathrm{C}$. This is the regeneration step of amine solvent, as $\mathrm{CO}_{2}$ is released from the amine solution. Recovery of $\mathrm{CH}_{4}$ is higher than $99 \%$ due to the sensitivity of the reaction with $\mathrm{CO}_{2}$ but methane loss may increase up to $4 \%$ because of dissolution in amine [81]. While the system has high sensitivity and low operational costs, the high initial investment and significant energy demand for regeneration of amine are some of its drawbacks [75]. By using these chemicals as solvents in the liquid phase, an extremely low $\mathrm{CH}_{4}$ adsorption is provided and $\mathrm{CH}_{4}$ recovery is achieved at a rate of approximately $99.95 \%$ [77]. In addition, the need for a lower operating pressure in the absorption processes with these chemicals compared to all other biogasupgrading technologies makes these technologies advantageous. In many amine washing plants, only one blower is used instead of a compressor, and this significantly reduces the electrical energy requirement. However, a disadvantage of amine scrubbing is the possible oxidative or thermal degradation of amine solutions. This increases the chemical consumption, corrosion potential, and emission potential of hazardous decomposition products [82].

Another method of separation of $\mathrm{CO}_{2}$ and $\mathrm{CH}_{4}$ is the adsorption of gas molecules to a solid surface. The adsorbent solid surfaces used for this process are porous materials with highly specific surface areas. The other name of this technique is pressure swing adsorption (PSA). This technique enables the selective separation of biogas by using different adsorption equilibria that adsorb larger amounts of $\mathrm{CO}_{2}$ or different adsorption 
kinetics that adsorb $\mathrm{CH}_{4}$ faster than $\mathrm{CO}_{2}$. The adsorbent materials used for this technique are titanosilicates, zeolites, silica gels, activated carbon, and carbon molecular sieves [24,83]. In the adsorption process to the solid surface, the water vapour in the biogas must be preseparated in order to prevent potential poisoning of the adsorbent material [29]. In addition, the pressure of the biogas fed must be 10 bar in order to provide sufficient driving force in this adsorption process. This method is able to adsorb $\mathrm{N}_{2}$ and $\mathrm{O}_{2}$ simultaneously with $\mathrm{CO}_{2}$. The technology is well developed and commercially available in the market with various range capacities between 10 and $10,000 \mathrm{~m}^{3} / \mathrm{h}$ [75]. The flow chart is shown in Figure 3. In this process, there are four vertical columns that are used for adsorption, depressurization, desorption, and pressurization sequences. $\mathrm{CH}_{4}$ recovery can be around $98-99 \%$ as a result of solid surface adsorption processes. The biggest advantage of this technology is that it enables $\mathrm{N}_{2}, \mathrm{O}_{2}$ and $\mathrm{CO}_{2}$ to be separated from raw biogas at the same time [29]. However, it is a disadvantage that the active sites on the adsorbent material used in adsorption separation technologies are blocked by $\mathrm{NH}_{3}$ and $\mathrm{H}_{2} \mathrm{~S}$ gases [58]. Additionally, the process efficiency can be influenced by impurities of raw biogas. Additionally, $2-4 \%$ of $\mathrm{CH}_{4}$ is lost during the process and reduction in this loss should recirculate the output of gases into the PSA system [24].

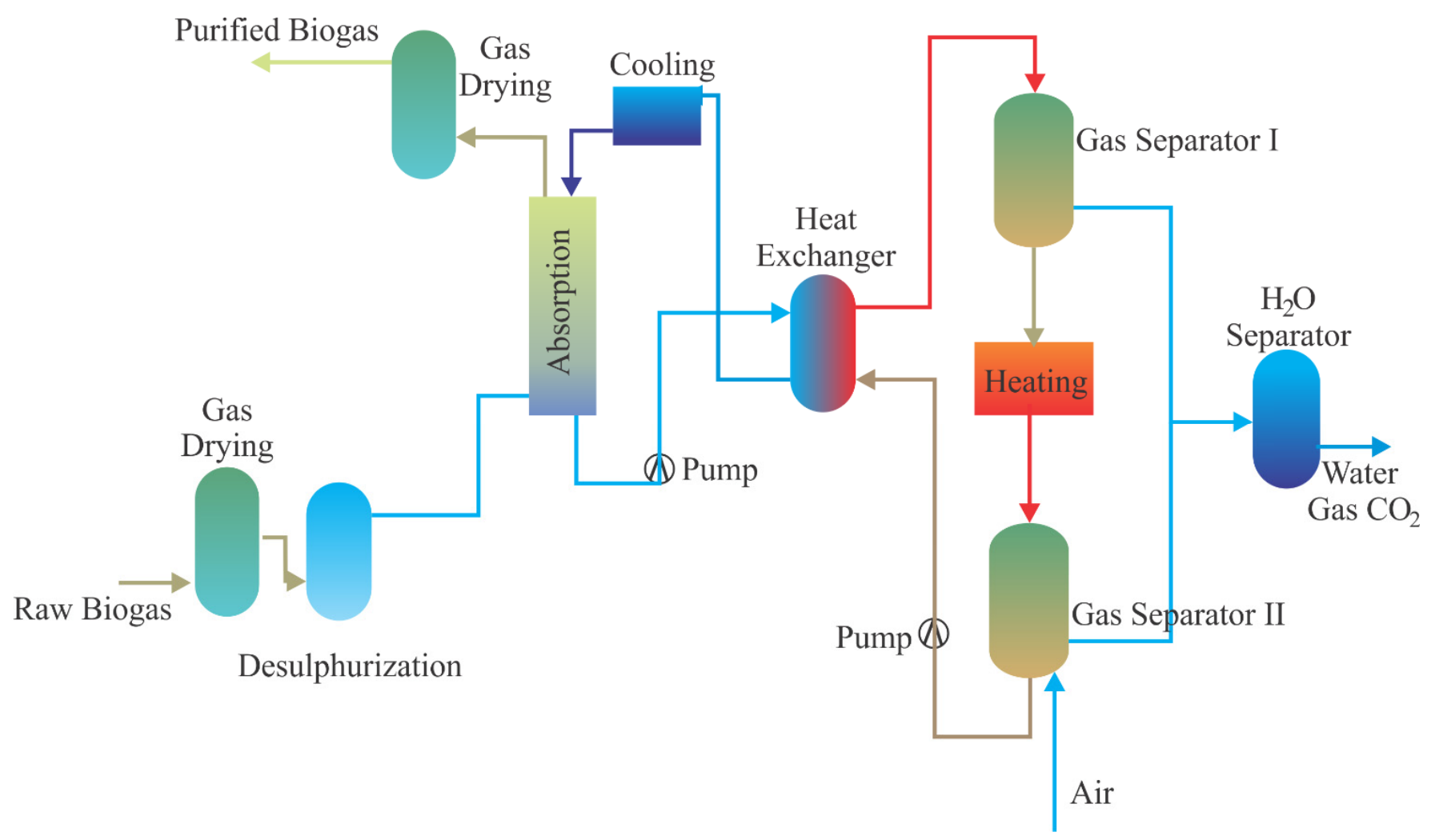

Figure 2. The schematic flow chart of chemical amine scrubbing (adapted from [24]).

Electrical swing adsorption (ESA) [84] and temperature swing adsorption (TSA) [85] are other swing adsorption methods. Temperature increases at constant pressure in the TSA process; therefore, thermal energy is required for the regeneration of the adsorbent material [86]. In an ESA process, the current passes through the saturated adsorbents for regeneration, so that $\mathrm{CO}_{2}$ is released from adsorbents as a result of heat generation by the Joule-heating phenomena. Even though the operating cost of ESA is lower than TSA and PSA, conductive adsorbent is needed. Activated carbon is a promising adsorbent due to its semiconductor properties with large surface area and porous structure [87]. 


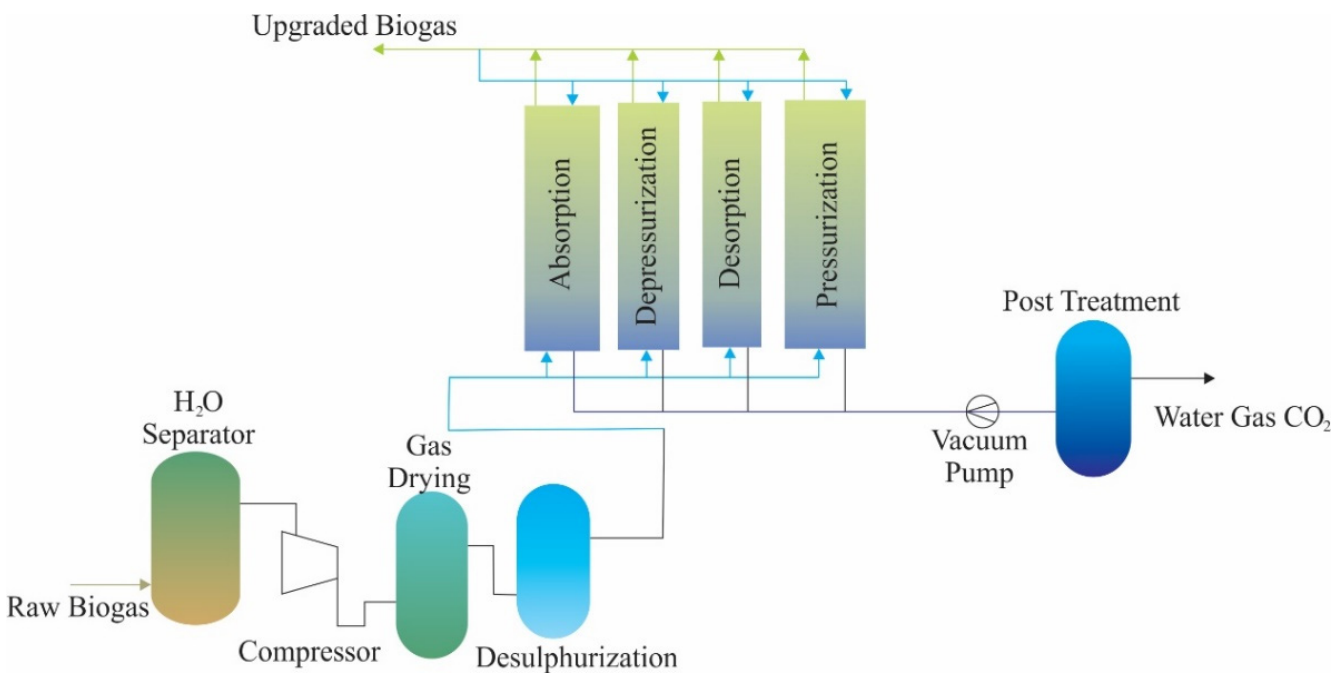

Figure 3. The schematic flow chart of pressure swing adsorption (PSA) (adapted from [24]).

Another biogas-upgrading technique is membrane-based gas permeability, and this technology has gained increasing importance in recent years [88]. This technique is based on different solubilities of gas types in particular membrane materials [89]. Figure 4 shows a schematic of process design for a membrane upgrading process. Biogas is fed into the membrane module at pressures of 5-30 bar [90]. Gas types with higher permeability in biogas preferably pass the membrane to the low-pressure permeable side, while gas types with lower permeability accumulate on the high-pressure side and leave the membrane module as a retentate. One of the challenges at membrane systems is energy demand to maintain pressure for separation, further studies should be conducted to reduce pressure demand. The most commonly used membrane materials in this technique are polysulphone, polyimide, and cellulose acetate [88]. It is a cheap membrane because of its cellulose-based material with good $\mathrm{CO}_{2}-\mathrm{CH}_{4}$ sensitivity. However, a cellulose acetate (CA) membrane has low plasticization pressure around 8 bars because $\mathrm{CO}_{2}$ can be dissolved in the matrix of the membrane due to its $\mathrm{OH}^{-}$-rich structure [91]. The membrane separation technique provides up to $99.5 \% \mathrm{CH}_{4}$ recovery and provides biomethane quality containing at least $99 \% \mathrm{CH}_{4}$, especially when membrane modules are used sequentially [92]. As a result, polymeric material-based membranes are heavily used in raw biogas separation. This method is advantageous in terms of its robustness, ease of use, lack of need for chemicals, flexibility of scaling up, low operating costs, low initial investment costs, low energy demand, and compact design [58]. Moreover, it should be considered that while $\mathrm{CH}_{4}$ is separated from biogas by membrane systems, another valuable and biologically produced product, $\mathrm{CO}_{2}$, is also separated from biogas for further usage. The main challenge is the relationship between permeability and selectivity. Therefore, a low permeable membrane is used together with a low selectivity one [75].

Inorganic membranes have excellent thermal stability, mechanical strength, and resistance against chemicals compared to organic membranes. The membranes are made from different materials such as zeolite, silica, activated carbon, metal-organic framework, and carbon nanotubes [75]. The most difficult part is to produce a defect-free structure for an inorganic membrane because the fabrication process requires continuous monitoring and a small mistake can create a defect due to their very fragile structure [93]. The defects in the structure are closely related to the sensitivity of membranes.

Considering that biogas components liquefy or sublimate at different temperatures, they can be used to remove impurities from biogas by the cryogenic separation method. Cryogenic separation is a technique that relies on the liquefaction of gases under different temperatures and pressures. Biogas is cooled down to $-55^{\circ} \mathrm{C}$, and moisture, $\mathrm{NH}_{3}$, and $\mathrm{H}_{2} \mathrm{~S}$ are removed and $\mathrm{CO}_{2}$ is separated as a liquid in the last step [21]. $\mathrm{CO}_{2}$ can be removed 
in solid form through sublimation when the temperature is decreased at $-85^{\circ} \mathrm{C}$. With this technique, the $\mathrm{CH}_{4}$ content of the gas phase at equilibrium is higher than $97 \%(v / v)$. Since cooling for purification is synergistic with cooling for liquefaction, this technique is particularly valuable in the case of producing liquefied biomethane. The process is run at a temperature of $-170{ }^{\circ} \mathrm{C}$ and under a pressure of 80 bars, which requires several compressors and heat exchangers [75]. In addition, other gasses such as $\mathrm{N}_{2}, \mathrm{O}_{2}$ and siloxanes in raw biogas can be separated. After this process, the final product is liquid biomethane which is free of $\mathrm{N}_{2}$ and $\mathrm{O}_{2}$ and is equivalent to liquid natural gas. The cryogenic separation method can produce not only over $97 \%$ pure biomethane in liquid form, but also the marketable liquid form of $\mathrm{CO}_{2}[76,94]$. The schematic flow chart of the cryogenic separation of biogas is shown in Figure 5.

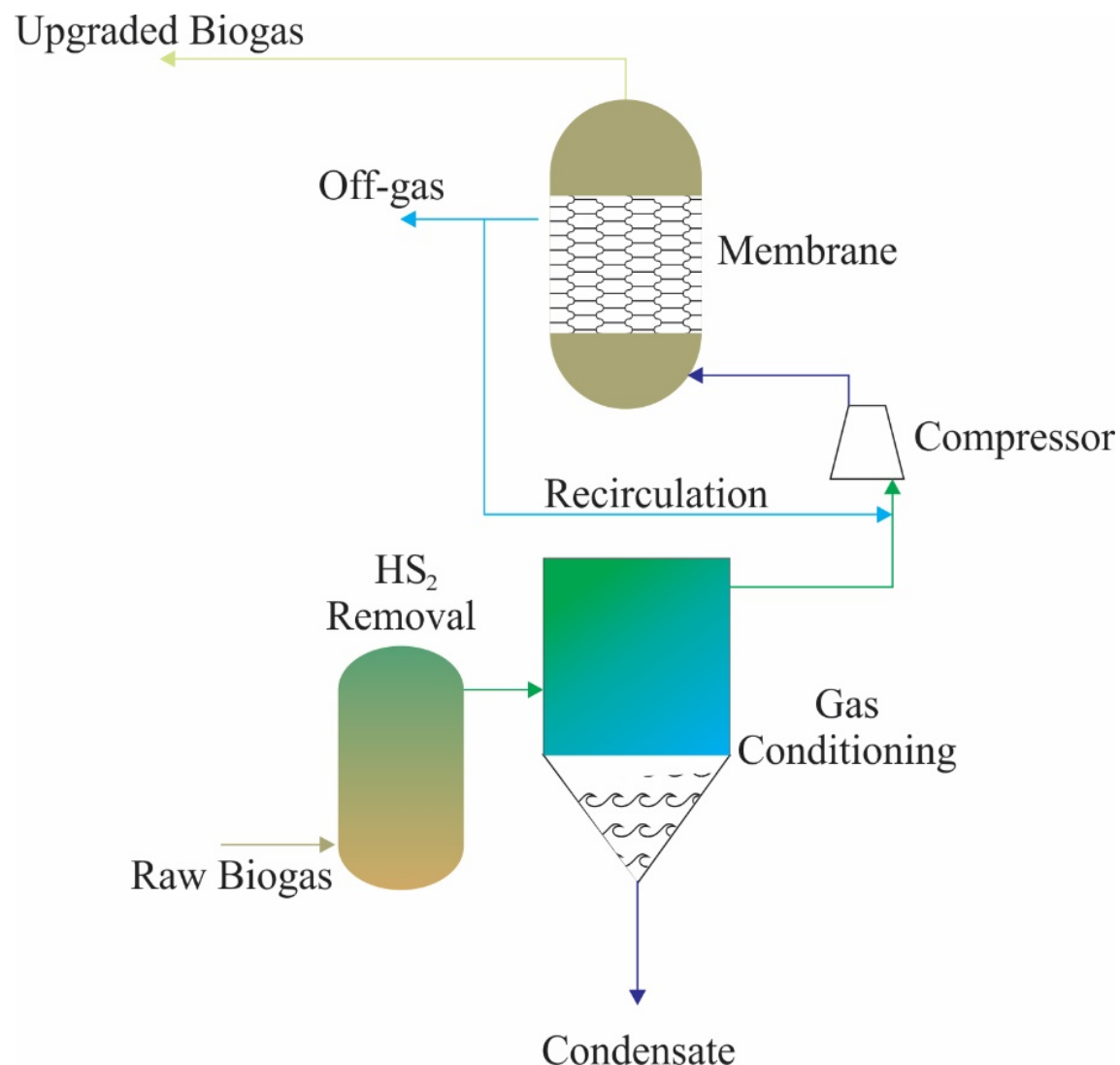

Figure 4. The schematic flow chart of a membrane separation process (adapted from [79]).

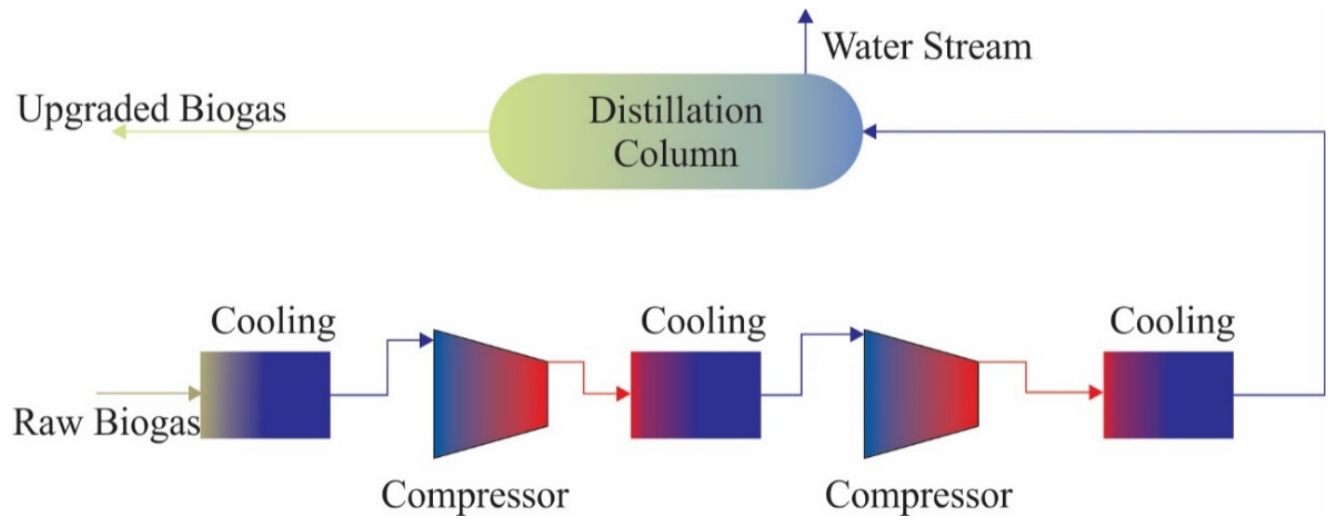

Figure 5. The schematic flow chart of the cryogenic separation of biogas (adapted from [24]). 
Although the cryogenic separation method has promising results, it is still in development and operates on a commercial scale for only a few facilities. High investment and operating costs, and $\mathrm{CH}_{4}$ losses and blockage due to solid $\mathrm{CO}_{2}$ are a few of the problems that limit the use of this technique [19].

\subsection{Biological Techniques for $\mathrm{CO}_{2}$ Removal}

Biological upgrade techniques can be classified as photosynthetic and chemoautotrophic. Most of these techniques have proven themselves in the experimental stage for being the early stage of full-scale applications. These technologies contribute to sustainable cyclic energy recovery by converting $\mathrm{CO}_{2}$ into other energy-containing products (i.e., $\mathrm{CH}_{4}$, $\mathrm{H}_{2}$, etc.). $\mathrm{CO}_{2}$ in biogas is converted to $\mathrm{CH}_{4}$ using $\mathrm{H}_{2}$, according to the chemoautotrophic upgrade method (Reaction (1)).

$$
4 \mathrm{H}_{2}+\mathrm{CO}_{2} \rightarrow \mathrm{CH}_{4}+\mathrm{H}_{2} \mathrm{O} \quad \Delta \mathrm{G}^{0}=-130.7 \mathrm{KJ} / \mathrm{mol}
$$

$\mathrm{H}_{2}$ gas should be obtained from renewable energy sources. For this, water is hydrolyzed and the remaining electrical energy can be provided by windmills or solar panels for this hydrolysis [95]. With the electrolysis of water made using this energy, water is divided into $\mathrm{O}_{2}$ and $\mathrm{H}_{2}$. However, the low volumetric energy density is a disadvantage that makes it difficult to store the $\mathrm{H}_{2}$ gas produced by this method [95]. The low initial investment costs are due to the fact that $\mathrm{CH}_{4}$ has an energy of $36 \mathrm{MJ} / \mathrm{m}^{3}, \mathrm{H}_{2}$ has an energy greater than $10.88 \mathrm{MJ} / \mathrm{m}^{3}$, and the existing possibilities of the biogas plant are used in the improvement processes which make this technology advantageous [96].

$\mathrm{H}_{2}$ gas-assisted biogas upgrade methods exist in three different forms: ex situ, in situ, and hybrid design techniques (Figure 6).

In the in situ concept, $\mathrm{H}_{2}$, externally added to anaerobic digester is converted to $\mathrm{CH}_{4}$ by combining with $\mathrm{CO}_{2}$ in the digester and by the action of autochthonous methanogenic archaea [97]. The biggest disadvantage of this technology is that it reduces the activity of the methanogenesis stage by increasing the $\mathrm{pH}$ value to above 8.5 in the biogas process. $\mathrm{CO}_{2}$ gas is decomposed into $\mathrm{H}^{+}$and $\mathrm{HCO}_{3}{ }^{-}$as shown in Reaction (2). Thus, the use of $\mathrm{CO}_{2}$ causes a reduction in $\mathrm{H}^{+}$gas and causes an increase in the $\mathrm{pH}$ of the environment.

$$
\mathrm{H}_{2} \mathrm{O}+\mathrm{CO}_{2} \rightarrow \mathrm{H}^{+}+\mathrm{HCO}_{3}^{-}
$$

In order to overcome this difficulty, it has been proposed that codigestion with acidic wastes can stop the $\mathrm{pH}$ increase [98]. Luo and Angelida [98] used hollow fiber membranes to inject $\mathrm{H}_{2}$ into an anaerobic reactor that processes cattle manure and whey in a continuously fed reactor and obtained methane gas containing $96 \% \mathrm{CH}_{4}$. In another study, a hollow fiber membrane in an upflow anaerobic sludge blanket reactor was placed in an external degassing unit, and biomethane containing $94 \% \mathrm{CH}_{4}$ was obtained from the in situ biogas upgrade process [99].

The ex situ biogas upgrade method is the process of transforming products into $\mathrm{CH}_{4}$ by supplying $\mathrm{H}_{2}$ and $\mathrm{CO}_{2}$ externally to a secondary vessel containing hydrogenotrophic culture outside the main anaerobic digester, as shown in Figure 6 [97]. This method has some advantages over in situ methods. These advantages include the benefit of the secondary vessel which makes the biochemical process simpler due to the absence of organic substrate degradation and makes the process independent of biomass. With this method, biomethane efficiency can be between $79-98 \%$. This yield may vary according to digester types. For example, $98-99 \%$ purity biomethane can be obtained due to the formation of a biofilm of a mixed anaerobic consortium, which acts as a good biocatalyst of a trickle bed reactor [100]. As a result, ex situ and in situ processes have taken their place among the hydrogen gas-assisted biogas upgrade techniques in the literature with their experimental results, but the hybrid design technique is currently in the developmental stage and the results of this technology will soon begin to emerge. 


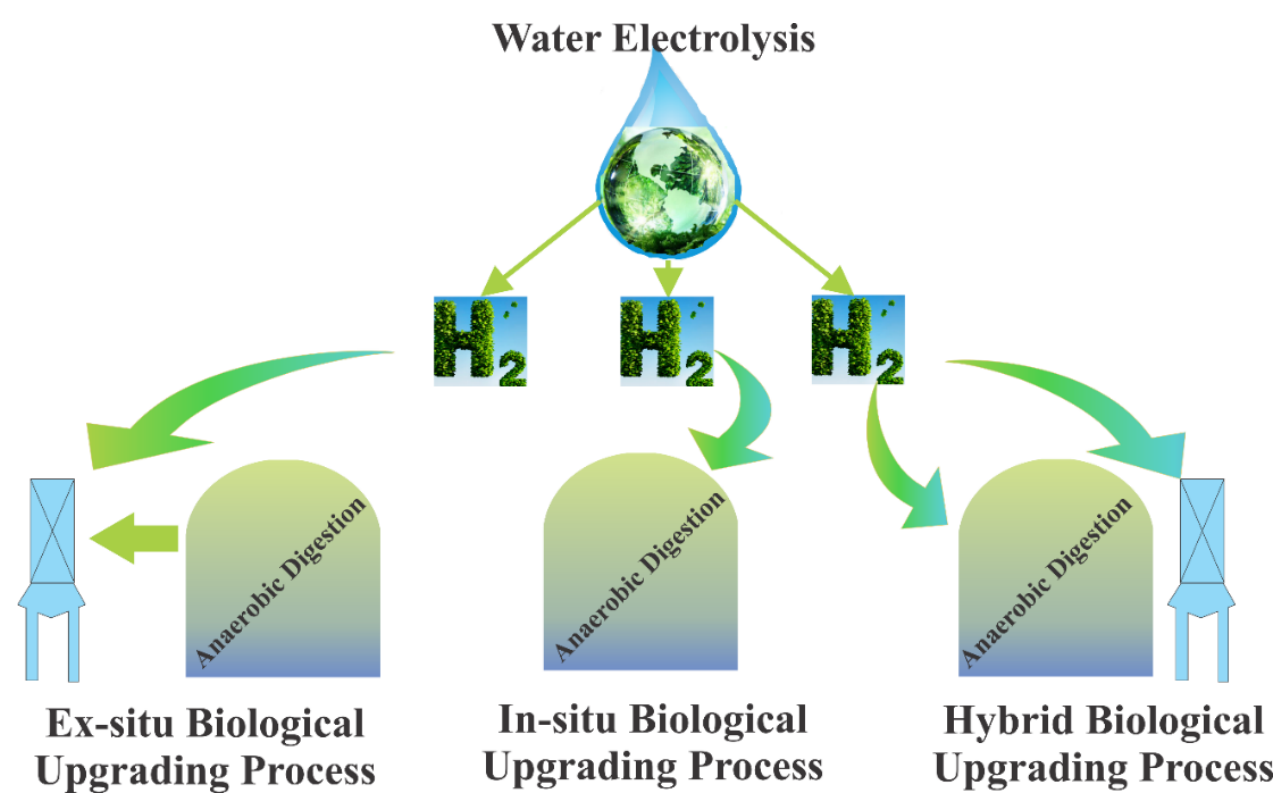

Figure 6. Hybrid, in situ, and ex situ biological upgrading technologies (adapted from [19]).

Another alternative method of $\mathrm{CO}_{2}$ separation is the photosynthetic biogas uptake technique. In addition to $\mathrm{CO}_{2}, \mathrm{H}_{2} \mathrm{~S}$ is also removed with this method and $>54 \% \mathrm{CO}_{2}$ is removed. The biomethane production efficiency of photoautotrophic techniques can increase up to $97 \%$, depending on the digester type and substrate. Closed systems are advantageous due to their low land and water requirements and high photosynthetic performance. However, open photobioreactors differ from closed systems in that they require fewer resources for construction and processing, have low photosynthetic $\mathrm{CO}_{2}$ removal, and have high natural-resource requirements. In the biogas-upgrading process, biogas is directly injected into photobioreactors, and then photoautotrophic microorganisms can efficiently take up $\mathrm{O}_{2}$ and $\mathrm{CO}_{2}$ to generate heat. Thus, up to $2-6 \% \mathrm{CO}_{2}$ can be found in the upgraded biogas and the $\mathrm{CH}_{4}$ ratio increases [101].

Various microalgae or cyanobacteria with high photosynthetic activity have been used to raise biogas quality. The most common of these are Spirulina, Chlorella, and Arthrospira [76]. Using microalgae to reduce the $\mathrm{CO}_{2}$ component in raw biogas has taken place successfully and achieved up to $97.07 \%$ of $\mathrm{CO}_{2}$ removal [102]. Another approach is indirectly upgrading biogas with microalgae as claimed by Chi et al. [103], which is a novel technique and was suggested as a two-step process to upgrade biogas while avoiding the risk of explosion. In the first step, biogas was passed through a carbonate solution to capture $\mathrm{CO}_{2}$ as a bicarbonate form. The second step is the regeneration of the carbonate solution. Figure 7 demonstrates direct and indirect biogas upgrading with microalgae.

\subsection{Removal of Hydrogen Sulfide}

$\mathrm{H}_{2} \mathrm{~S}$ is another common component of raw biogas. Its quantity is between 100 and $10,000 \mathrm{ppm}$ and the variation depends on the substrate combination [24]. If the substrate is rich in protein content, $\mathrm{H}_{2} \mathrm{~S}$ production will be high. Due to its negative effects such as causing the corrosion of pipes, pumps, and engines, it has to be cleaned before upgrading to biomethane or any other use of biogas. $\mathrm{H}_{2} \mathrm{~S}$ can be transformed into $\mathrm{SO}_{2}$ and sulphuric acid $\left(\mathrm{H}_{2} \mathrm{SO}_{4}\right)$ which increase environmental concerns and corrosion risk. 


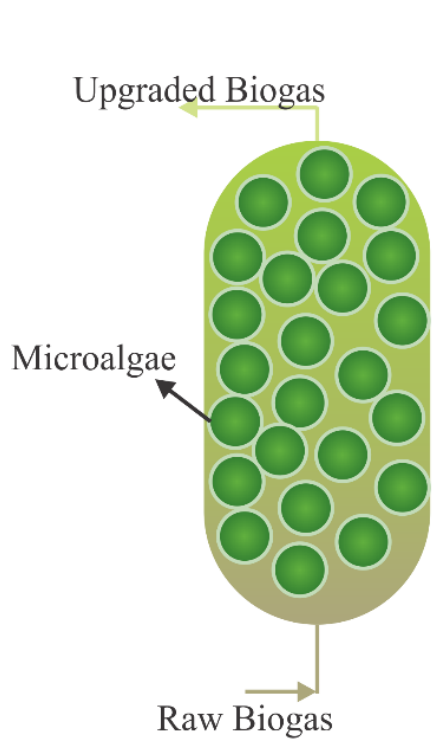

(a)

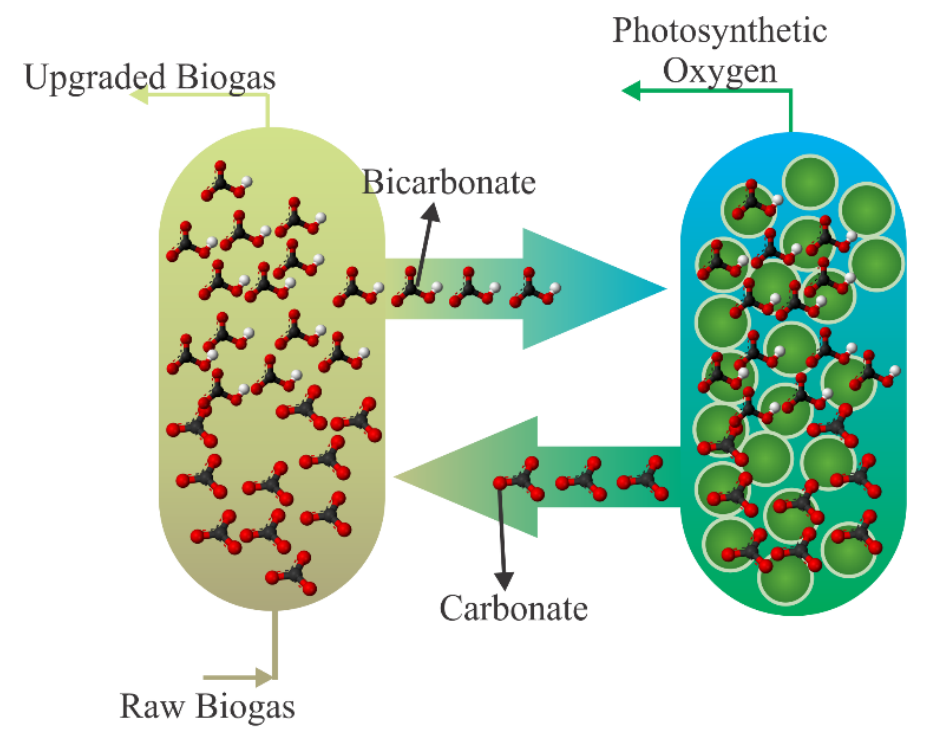

(b)

Figure 7. The schematic flow chart of (a) direct and (b) indirect upgrading biogas using microalgae (adapted from [104]).

The simplest desulphurisation methods are accomplished by introducing pure oxygen or air into the gas phase or adding iron hydroxides or chlorides to the liquid phase [21]. The addition of iron hydroxides or chlorides to the liquid phase causes ferrous sulfide formation and precipitation and can significantly reduce the concentration of $\mathrm{H}_{2} \mathrm{~S}$ in the gas phase. $\mathrm{O}_{2}$ added to the gas phase is consumed by Thiobacillus bacteria along with the oxidation of $\mathrm{H}_{2} \mathrm{~S}$ to elemental sulphur deposited on surfaces or absorbed by the slurry [105]. These techniques create minimum additional operating and investment costs but can provide removal of $80-99 \% \mathrm{H}_{2} \mathrm{~S}$ concentrations. However, it is known to be less efficient in obtaining stable and low sulphur contents required for biomethane production. The disadvantages of the method are that oxygen can affect the anaerobic digestion process negatively if too much air is injected. Additionally, the remaining nitrogen could be a problem for future processes. For example, it is difficult to upgrade by separating nitrogen and methane [106]. Application to filter reactors is commonly used on the output of the biogas pipe. With this method, combinations of $\mathrm{H}_{2} \mathrm{~S}$ in raw biogas can achieve a range of 50-100 ppm [107].

The oldest technique used in the removal of $\mathrm{H}_{2} \mathrm{~S}$ from biogas is scrubbing with chemically active liquids. The most used scrubbing chemicals are sodium hydroxide $(\mathrm{NaOH})$, calcium hydroxide $\left(\mathrm{Ca}(\mathrm{OH})_{2}\right)$, iron (II) chloride, iron (III) hydroxide, ethylenediaminetetraacetic acid, and monoethanolamine [108-110]. $\mathrm{Ca}(\mathrm{OH})_{2}$ and $\mathrm{NaOH}$ allow for the formation of sulphurous salts. It has been reported that with these techniques, $90-100 \%$ cleansing is normally achieved. The biggest disadvantages of chemical upgrading techniques are the necessity and high costs of using chemicals [108]. In this method, $\mathrm{Fe}^{3+} /$ EDTA catalyst is used where the reaction product is elemental sulphur. During the reaction, $\mathrm{Fe}^{3+}$ is reduced to $\mathrm{Fe}^{2+}$ as shown in Reaction (3). The regeneration process is represented in Reactions (4) and (5) [24]. During the $\mathrm{H}_{2} \mathrm{~S}$ cleaning process, a small amount of $\mathrm{Fe}^{3+}$ /EDTA solution is used for the regeneration step. $\mathrm{H}_{2} \mathrm{~S}$ removal of $90-100 \%$ is achieved when raw biogas and solution flow rates are $1 \mathrm{dm}^{3} / \mathrm{min}$ and $83.6 \mathrm{~cm}^{3} / \mathrm{min}$, respectively [21].

$$
\begin{gathered}
2 \mathrm{~S}^{2-}+2 \mathrm{~F}^{3+} \rightarrow \mathrm{S}+2 \mathrm{Fe}^{2+} \\
\mathrm{O}_{2}+2 \mathrm{H}_{2} \mathrm{O} \rightarrow \mathrm{O}_{2} \\
0.5 \mathrm{O}_{2}+2 \mathrm{Fe}^{2+} \rightarrow 2 \mathrm{Fe}^{3+}+2 \mathrm{OH}^{-}
\end{gathered}
$$


$\mathrm{H}_{2} \mathrm{~S}$ can be separated from biogas by adsorption in hydroxides or metal oxides, and the most commonly used chemicals are iron, zinc and copper oxides [21]. At the end of this process, sulphur binds as metal sulphur and is released into the gas thanks to a mild endothermic reaction.

The membrane separation technique can also be applied to separate $\mathrm{H}_{2} \mathrm{~S}$ from biogas [111]. However, it should be noted that the efficiency of $\mathrm{H}_{2} \mathrm{~S}$ removal will be limited when glassy polymeric material is used only for bulk $\mathrm{CO}_{2}$ removal. High $\mathrm{CH}_{4} / \mathrm{H}_{2} \mathrm{~S}$ separation can be achieved by selecting a special, rubbery, polymeric membrane material. This technique is very attractive for biogas with $\mathrm{H}_{2} \mathrm{~S}$ content higher than $2 \%$ [112].

High-pressure water washing (HPWS) is a biogas-boosting technology that is frequently used industrially [113]. Water is used for single-pass absorption; however, without a regeneration step, the process has high water consumption [24]. Therefore, it prefers a small absorption tank volume. This method is more efficient for smaller concentrations of $\mathrm{H}_{2} \mathrm{~S}$ or combinations of $\mathrm{CO}_{2}$ removal. As shown in Figure 8, the adsorption process occurs in a high pressure (6-10 bar) column in which the biogas is washed with an HPWS and biomethane exiting the top of the column is obtained. A disadvantage of this technique is that it is affected by higher water consumption than other adsorbing techniques [114].

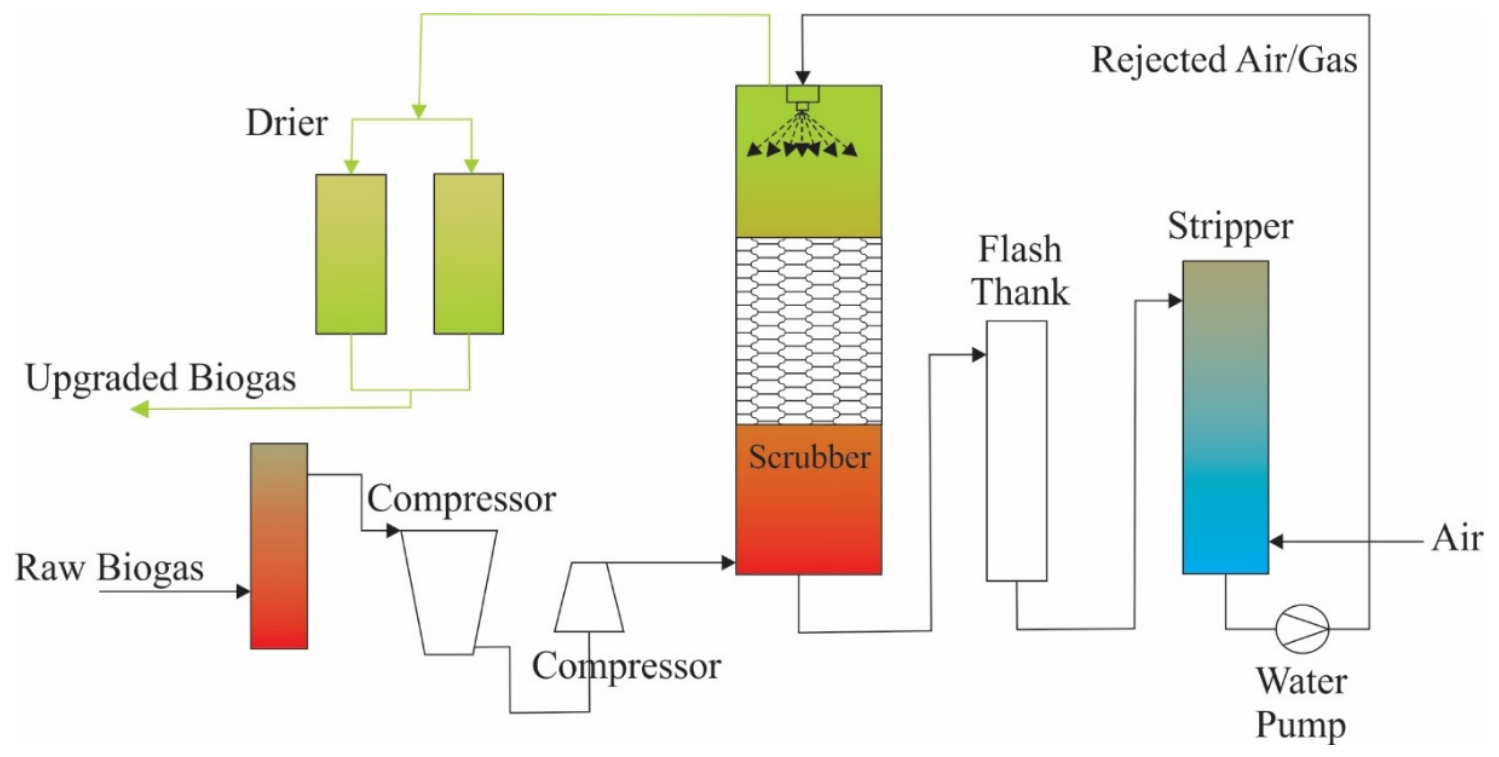

Figure 8. The schematic flow chart of water scrubbing of $\mathrm{H}_{2} \mathrm{~S}$ (adopted from [24]).

$\mathrm{H}_{2} \mathrm{~S}$ removal from biogas can be achieved using adsorption to activated carbons impregnated with potassium iodide or $\mathrm{H}_{2} \mathrm{SO}_{4}$ or not impregnated (untreated) [24]. For this, $4-6 \% \mathrm{O}_{2}$ must be added to the biogas to reduce $\mathrm{H}_{2} \mathrm{~S}$ to elemental sulphur (Reaction 6) [21].

$$
2 \mathrm{H}_{2} \mathrm{~S}+\mathrm{O}_{2} \rightarrow 2 \mathrm{~S}+2 \mathrm{H}_{2} \mathrm{O}
$$

The temperature required for this reaction to occur is $50-70{ }^{\circ} \mathrm{C}$ and the required pressure is 7-8 bar. As seen in Figure 9, the elemental sulphur obtained is adsorbed by activated carbon. To improve the reaction rate, adsorption is done by impregnating the activated carbon with an oxide or alkali such as sodium potassium iodine, potassium hydroxide and potassium permanganate. This process can increase the $\mathrm{H}_{2} \mathrm{~S}$ removal from $10-20 \mathrm{~kg} \mathrm{H}_{2} \mathrm{~S} / \mathrm{m}^{3}$ to $120-140 \mathrm{~kg} \mathrm{H}_{2} \mathrm{~S} / \mathrm{m}^{3}$ [115].

While this technology has advantages such as high $\mathrm{H}_{2} \mathrm{~S}$ cleaning efficiency and high purity, it has disadvantages such as the need for replacing activated carbon instead of regeneration when the solid is saturated with sulphur, increasing environmental concerns about proper disposal methods (such as creating waste oxygen), and removing dust and water prior to activated carbon treatment [76]. 


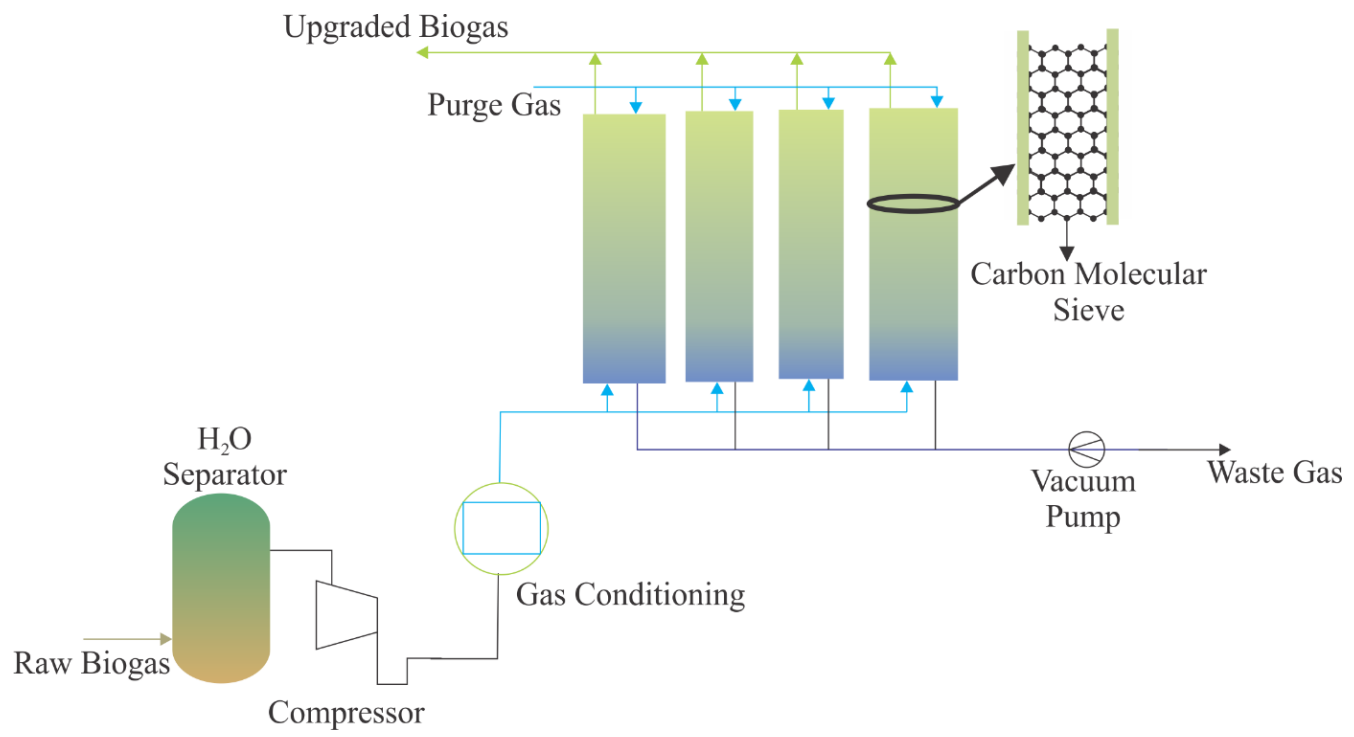

Figure 9. PSA technique flow chart for $\mathrm{H}_{2} \mathrm{~S}$ removal (adapted from [24]).

\subsection{Biological Techniques for Removal of $\mathrm{H}_{2} \mathrm{~S}$}

Biological oxidation can be performed ex situ in a distinct apparatus with packed bed scrubbers or trickling beds [21]. $\mathrm{H}_{2} \mathrm{~S}$ is absorbed in a liquid film and bio-oxidized to sulfur or sulfate. Washing liquid is drained and replaced if the $\mathrm{pH}$ falls below the threshold level. $\mathrm{O}_{2}$ should be dosed as pure air or as pure $\mathrm{O}_{2}$ (Reactions 7 and 8). Although the separation performance of this technique is effective, the fact that $\mathrm{H}_{2} \mathrm{~S}$ levels of less than $100 \mathrm{ppm}$ cannot be reached continuously for the remaining $\mathrm{O}_{2}$ content prevents the continuous application of this technique in biomethane production [109].

$$
\begin{gathered}
\mathrm{H}_{2} \mathrm{~S}+0.5 \mathrm{O}_{2} \rightarrow \mathrm{S}+\mathrm{H}_{2} \mathrm{O} \\
\mathrm{H}_{2} \mathrm{~S}+2 \mathrm{O}_{2} \rightarrow \mathrm{SO}_{4}^{2-}+2 \mathrm{H}^{+}
\end{gathered}
$$

In addition to this technique, it has been reported in the literature that $\mathrm{NO}_{3}$ can be used as an electron acceptor instead of $\mathrm{O}_{2}$ for $\mathrm{H}_{2} \mathrm{~S}$ oxidation in the biofiltration unit (Reactions 9 and 10) [116].

$$
\begin{gathered}
3 \mathrm{H}_{2} \mathrm{~S}+\mathrm{NO}_{3}^{-} \rightarrow 3 \mathrm{~S}+0.5 \mathrm{~N}_{2}+3 \mathrm{H}_{2} \mathrm{O} \\
3 \mathrm{H}_{2} \mathrm{~S}+4 \mathrm{NO}_{3}^{-} \rightarrow 3 \mathrm{SO}_{4}^{2-}+2 \mathrm{~N}_{2}+6 \mathrm{H}^{+}
\end{gathered}
$$

The sulphur-oxidizing microorganisms used here belong to the Thiomonas, Thiobacillus, Acidithiobacillus, Paracoccus, Halothiobacillus or Sulfurimonas genera [117]. This technique has been mainly applied in a biotrickling filter due to its low cost and nutrient requirement.

With this technology, the $\mathrm{H}_{2} \mathrm{~S}$ concentration can be reduced from 3000-5000 ppm to 50-100 ppm, and at the same time, $\mathrm{NH}_{3}$ is removed. In the biotic filter, HD-QPAC, pall rings or polyurethane foam are used as filled bed column materials for $\mathrm{H}_{2} \mathrm{~S}$ removal $[24,76]$.

\subsection{Removal of Other Compounds}

\subsubsection{Removal of Siloxanes}

$\mathrm{SiO}_{2}$ deposits in the spark plug, cylinder head, and combustion chamber which can cause damage to the engine. Maximum siloxane concentrations in biogas should be between 0.03 and $28 \mathrm{mg} / \mathrm{m}^{3}$ according to engine manufactures [21]. A study showed that while most siloxanes can be eliminated with long carbon-chain organic solvents, they can be completely removed with chemical absorption [118]. Removal of $95 \%$ of the siloxane concentration at $60{ }^{\circ} \mathrm{C}$ was achieved using a combination of sulphuric acid and nitric acid at 480 and $650 \mathrm{~L} / \mathrm{m}^{3}$, respectively [118]. In addition, selexol can be used to remove at least $98 \%$ of siloxane in biogas plants [119]. 
Using silica gel is another method and experimental reports show that its removal capacity is higher than activated carbon; however, using silica gel may only be effective in large-scale uses [21].

The activated carbon adsorption method can be used for siloxane removal from biogas. The siloxane adsorption efficiency of this method depends on the adsorption capacity, physicochemical properties, and microporous volumes of the activated carbon [120]. Schweigkofler and Niessner [118] have reported on using different types of adsorbents such as activated carbon, polymer beads, silica gel, and molecular sieves for siloxane removal, and found that they exhibit good adsorption capacity. The cryogenic separation method is another advantageous technology. With the cryogenic separation method, siloxane concentrations can be removed from raw biogas at $12 \%, 25.9 \%, 90 \%$, and $99.3 \%$ at temperatures of $5{ }^{\circ} \mathrm{C},-25{ }^{\circ} \mathrm{C},-30{ }^{\circ} \mathrm{C}$, and $-70{ }^{\circ} \mathrm{C}$, respectively. The initial investment and operating costs of any technique involving cryogenation are higher than other adsorption methods such as activated carbon [121].

The membrane separation technique can alternatively be used to remove siloxanes from biogas. For this purpose, membranes with high methane/siloxane content can be used [122]. Although membrane separation techniques are very well established for mostly $\mathrm{CO}_{2}$ removal from biogas in industrial applications, there are only a few published results applying the membrane technique for more than $80 \%$ siloxane removal. Recently, a new method has been developed to remove siloxanes using a cryogenic temperature condensation system by Piechota [62]. In the study, the temperature of the system ranged between +40 to $-50{ }^{\circ} \mathrm{C}$ with different biogas flow rates, and $99.87 \%$ of siloxane removal was achieved; moreover, the obtained biogas met biomethane requirements from the European Union [62]. The same author has published another method for the removal of siloxanes and the improvement of biogas quality [123]. A specially designed adsorptive packed column system was developed, and the remarkable results obtained show that siloxanes were removed entirely and nonsilica impurities were eliminated by $99.76 \%$ in comparison to the intake biogas [123].

\subsubsection{Removal of Water}

Biogas is mostly saturated with water vapour after leaving the digesters operating at mesophilic temperatures. Water in the form of vapour in biogas can condense in gas pipelines or cause corrosion with sulphur compounds. Raw biogas, which has 5\% water at $35^{\circ} \mathrm{C}$ as saturated water vapour, can be removed by changing the pressure and temperature. When the pressure is increased or the temperature is decreased, water vapour will condense as a physical separation method. Additionally, absorption and adsorption methods can be applied to remove the water as a chemical drying method. Adsorption separation techniques include activated charcoal, molecular sieves, or silica. Other impurities such as siloxanes and particles can dissolve in water [106]. When removing water vapour in raw biogas, these impurities will be simultaneously removed.

Physical separation methods can be divided into three main groups which are namely cyclone separators which use centrifugal force for separation of water droplets, moisture traps which use a pressure differential to create a low temperature and condense water, and water traps which use a design of pipes to collect water $[24,76,107]$. These methods have a chronic operating problem where water freezes on the surface of a heat exchanger [76]. The dew point of biogas can be decreased to $-40{ }^{\circ} \mathrm{C}$ using water adsorption under 6-10 bar pressure in the columns. Silica, alumina, magnesium oxide, or activated carbon is placed inside the pressurized columns. For continuous operation, two columns are needed. When one of them runs until saturation, the other regenerates at low pressure simultaneously. A benefit is that this system has a low operating cost. However, high initial investment costs and the required precleaning of dust and oil particles are drawbacks of the system [76]. When using the water absorption method with glycols, the biogas dew point can be decreased to $-15^{\circ} \mathrm{C}$. One of the benefits of this system is that precleaning of dust and oil particles is not necessary. However, the solvent regenerates at $200{ }^{\circ} \mathrm{C}$ which causes high 
operating costs. Ryckebosch et al. [21] reported that the biogas flow rate should be at least $500 \mathrm{~m}^{3} / \mathrm{h}$ for the economic benefits of the glycol-based system.

\subsubsection{Removal of Ammonia}

Ammonia is another common impurity. If the substrate contains proteins, ammonia is produced during hydrolysis. $\mathrm{NH}_{3}$ is removed during the recovery or primary drying of the biogas and during the adsorption process.

Guo et al. [124] designed a packed bed N-TRAP system impregnated with $\mathrm{H}_{2} \mathrm{SO}_{4}$ for $\mathrm{NH}_{3}$ removal from biogas. The adsorbent in the N-TRAP system was prepared with waste wood-shaving sand and anaerobic digestion biowaste which had a higher adsorption capacity than activated carbon when under the same conditions. In addition, this system is advantageous in that it can be applied in the presence of water, unlike activated carbon, and the adsorbent saturated with $\mathrm{NH}_{3}$ can be used as fertilizer.

Co-removal processes involving biological techniques for the removal of $\mathrm{H}_{2} \mathrm{~S}$ and $\mathrm{NH}_{3}$ as a mixture have also been reported. Jiang et al. [125] suggested a horizontal biotrickling filter packed with exhausted activated carbon for the co-removal of $\mathrm{H}_{2} \mathrm{~S}$ and $\mathrm{NH}_{3}$ from biogas. The biofilter used was inoculated with nitrifying bacteria that oxidize sulphur. The removal efficiency for $\mathrm{H}_{2} \mathrm{~S}$ was $95 \%$ for a $20-100 \mathrm{ppm}$ operating range and $8 \mathrm{~s}$ gas residence time. For gas residence time longer than $4 \mathrm{~s}, \mathrm{NH}_{3}$ removal efficiency reached $98 \%$. However, $\mathrm{NH}_{3}$ degradation resulting from high $\mathrm{H}_{2} \mathrm{~S}$ concentration has been observed [126]. These effects may be due to the accumulation of ammonium sulfate $\left(\left(\mathrm{NH}_{4}\right) \mathrm{SO}_{4}\right)$ in the system.

Alternatively, $\mathrm{NH}_{3}$ can be extracted from the biogas along with other unwanted components. For example, as mentioned in the previous sections, sulphur compounds and halogenated compounds in biogas can be removed in addition to ammonia by using a water-scrubbing method [75]. In addition, $\mathrm{NH}_{3}$ and water vapour can also be removed together using a PSA system.

\subsubsection{Removal of Oxygen and Nitrogen}

$\mathrm{N}_{2}$ and $\mathrm{O}_{2}$ are generally absent in the reactor because of anaerobic conditions. If $\mathrm{N}_{2}$ is detected in raw biogas, it is a strong sign of air leakage in the reactor because $\mathrm{O}_{2}$ will react with $\mathrm{H}_{2} \mathrm{~S}$ and oxygen itself will not be detected. Its presence in biogas is undesirable due to the diluent effect that may cause a decrease in methane content. $\mathrm{O}_{2}$ can be tolerated up to some amount in biogas, but high amounts are undesirable as the risk of biogas explosion increases.

$\mathrm{O}_{2}$ and $\mathrm{N}_{2}$ can be removed from biogas by the adsorption method using a molecular sieve or activated carbon. PSA or membranes used for sulphur and $\mathrm{CO}_{2}$ removal can remove some of the $\mathrm{O}_{2}$ and $\mathrm{N}_{2}$. As a result, both components are difficult and expensive to extract from biogas [109]. Therefore, it is necessary to develop and apply new biogasboosting technologies to remove $\mathrm{N}_{2}$ and $\mathrm{O}_{2}$.

\subsubsection{Comparison of Different Technologies to Upgrade Biogas}

The most common upgrade technologies today are PSA, amine wash, and water scrubbing. PSA can actually be improved with newer and better-performing adsorbents [79]. Organic solvent washing is a highly effective upgrade technique, but there is no clear trend for this technology to increase or decrease within the biogas upgrade market. The development of this technology mostly depends on studies such as the optimization of pressure and temperature adsorption amounts. Additionally, organic solvent washing technology requires annual compensation of solvent lost to the atmosphere, which will increase the cost [79].

New process cycles are being developed to optimize methane yields, removal of unwanted gases from biogas, and energy demand [89]. The least-mature technology among these is membrane separation technology, but it has recently begun to develop rapidly in industrial applications [19]. The membrane separation technologies are attractive in terms of lower investment and operating costs compared to other techniques. Membrane 
separation technologies have proven to be suitable to replace other upgrading technologies. Polymeric membranes used in membrane separation technologies are preferred because of their low cost and flexibility [127]. However, the high cost of this technique and the impermeability of membranes to foreign matter limit the use of this technique. It was also stated that the membrane separation technique is relatively more expensive than the PSA technique [128].

If biogas-upgrading technologies are evaluated in terms of biomethane purity, the most important parameter is to remove $\mathrm{CO}_{2}$. Many upgrade technologies can obtain biomethane with $97 \%$ methane content, but high energy demand and increased costs occur for biomethane higher than $97 \%$. For example, in the case of substantial $\mathrm{N}_{2}$ in biogas, a complex adsorbent bed configuration can be used to remove this gas. This will result in both little refinement and a relatively high cost.

Table 4 compares the effects of different biogas uptake techniques in terms of methane recovery, biomethane purity, and electrical energy demands. Among the biogas-boosting techniques, the amine-scrubbing method appears to have relatively less electricity consumption, $\mathrm{CH}_{4}$ losses, and purer biomethane compared to other methods. However, amine scrubbers may need antifoaming agents. Additionally, since the amine washing technique is chemical adsorption, it should not be forgotten that the efficiency and effects of this technique will vary depending on the chemical used.

Table 4. Comparison of the effects of some biogas-upgrading technologies.

\begin{tabular}{|c|c|c|c|c|}
\hline Biogas Upgrading Methods & $\begin{array}{l}\mathrm{CH}_{4} \text { Losses } \\
\left(\% \text { v/v } \mathrm{CH}_{4}\right)\end{array}$ & $\begin{array}{l}\text { Biomethane Purity } \\
\left(\% \text { v/v } \mathrm{CH}_{4}\right)\end{array}$ & $\begin{array}{c}\text { Electrical Energy } \\
\text { Consumption }\left(\mathrm{kWh} / \mathrm{Nm}^{3}\right)\end{array}$ & Refs. \\
\hline \multirow{11}{*}{$\begin{array}{l}\text { Water } \\
\text { Scrubbing }\end{array}$} & 1 & 97 & $0.20-0.30$ & [129] \\
\hline & - & $>97$ & - & [130] \\
\hline & $<2$ & $80-99$ & - & [29] \\
\hline & $<2$ & $95-98$ & $0.2-0.5$ & [131] \\
\hline & $<2$ & $96-98$ & $0.25-0.3$ & [19] \\
\hline & 2 & $95-97$ & 0.25 & [12] \\
\hline & 1 & 96.5 & $0.26-0.27$ & [114] \\
\hline & $0.5-2$ & 96 & $0.25-0.30$ & [132] \\
\hline & $1-2$ & $96-98$ & $0.20-0.32$ & [29] \\
\hline & 1 & $96-98$ & $0.20-0.30$ & [133] \\
\hline & $1-3$ & 95-98 & $0.20-0.50$ & [17] \\
\hline \multirow{11}{*}{$\begin{array}{l}\text { Pressure swing } \\
\text { adsorption }\end{array}$} & 4 & $96-98$ & $0.23-0.30$ & [19] \\
\hline & $1-5$ & $90-98.5$ & $0.20-0.25$ & [134] \\
\hline & 2 & 98 & $0.21-0.46$ & [78] \\
\hline & 4 & $95-99$ & 0.24 & [75] \\
\hline & $1-3$ & 96 & $0.20-0.25$ & [129] \\
\hline & 2 & 96 & 0.18 & [114] \\
\hline & 4 & 95-99 & - & [130] \\
\hline & $<3$ & $>96-98$ & $0.16-0.43$ & [131] \\
\hline & $2-4$ & 95-99 & 0.25 & [12] \\
\hline & $1-3.5$ & $96-98$ & $0.16-0.43$ & [17] \\
\hline & 2 & 96 & 0.22 & [114] \\
\hline
\end{tabular}


Table 4. Cont.

\begin{tabular}{|c|c|c|c|c|}
\hline Biogas Upgrading Methods & $\begin{array}{l}\mathrm{CH}_{4} \text { Losses } \\
\left(\% \text { v/v } \mathrm{CH}_{4}\right)\end{array}$ & $\begin{array}{l}\text { Biomethane Purity } \\
\left(\% \text { v/v } \mathrm{CH}_{4}\right)\end{array}$ & $\begin{array}{c}\text { Electrical Energy } \\
\text { Consumption }\left(\mathrm{kWh} / \mathrm{Nm}^{3}\right)\end{array}$ & Refs. \\
\hline \multirow{11}{*}{$\begin{array}{l}\text { Membrane } \\
\text { separation }\end{array}$} & 4 & 96 & $0.19-0.77$ & [94] \\
\hline & - & $>96$ & - & [130] \\
\hline & 0.6 & $96-98$ & $0.18-0.20$ & [19] \\
\hline & $<5$ & $90-99$ & $0.18-0.35$ & [131] \\
\hline & 0.5 & 98 & $0.20-0.30$ & [79] \\
\hline & 0.5 & 98 & $0.20-0.30$ & [133] \\
\hline & 1 & 97 & 0.30 & [114] \\
\hline & $0.3-0.5$ & 95 & 0.25 & [129] \\
\hline & 0.8 & 99.5 & 0.26 & [135] \\
\hline & 0.7 & 97.5 & 0.29 & [136] \\
\hline & 0.1 & $96-99$ & $0.05-0.15$ & [19] \\
\hline \multirow{8}{*}{$\begin{array}{l}\text { Amine } \\
\text { scrubbing }\end{array}$} & $<1$ & $>99.0$ & 0.22 & [130] \\
\hline & 0.1 & 99.9 & $0.12-0.14$ & [79] \\
\hline & 0.1 & 99 & 0.15 & [129] \\
\hline & $0.04-0.1$ & 98 & $0.05-0.25$ & [17] \\
\hline & $<0.5$ & 98 & $0.05-0.18$ & [131] \\
\hline & 0.1 & 99 & $0.12-0.14$ & [133] \\
\hline & 0.1 & 99 & $0.12-0.14$ & [12] \\
\hline & 0.1 & 99 & $0.05-0.25$ & [134] \\
\hline
\end{tabular}

Another parameter effective in comparing the upgrade techniques is the size of the plant. For example, although the water-scrubbing technique in small plants is relatively less costly compared to other techniques, it has shown a higher cost compared to the PSA technique. Considering the external costs, the choice of upgrade technologies for each system is not affected much by the other. Considering this situation, chemical adsorption technology is preferred as it causes less $\mathrm{CH}_{4}$ loss compared to other techniques [114]. Waterscrubbing and PSA techniques suffer from higher methane loss and lower biomethane yield than other technologies. However, these techniques are quite suitable for small installations [128].

Converting biogas to biomethane is a strategic goal in many countries. Nonbiological (physicochemical) upgrade techniques have taken place in the literature with many applications and are at the level of high technology preparation. Biological techniques, on the other hand, are quite new technologies compared to other techniques and are advantageous in terms of feasibility and technological facilities. The development of biological upgrade technologies will be rapid and advantageous as the identified challenges are overcome.

\section{Utilization of Biogas}

As a renewable energy resource, biogas has gained enormous attention and the use of biogas is expected to increase considerably in the near future. According to estimations, the utilization of biogas will be $29.5 \mathrm{GW}$ globally in 2022 while it was only $14.5 \mathrm{GW}$ in 2012 [137]. Biogas can be used in a raw or upgraded form with different applications such as in a boiler to produce heat, combined heat and power (CHP) to produce heat and power, fuel cells to produce electricity, production of chemicals, production of vehicle fuels, and injection to the gas grid $[26,138]$. In the EU, electricity generated from biogas was $22 \mathrm{TW}$ h/year in 2020 [139]. Moreover, the expectation is that it will reach $640 \mathrm{TW}$ h/year, a 30-fold increase [140]. After 2017, greenhouse gas emissions were reduced by $60 \%$ due to 
biogas utilization [75]. Additionally, the estimation of biogas utilization for vehicle fuel shows that it may increase from $2 \%$ in 2017 to $27 \%$ in 2050 [75]. In the US, there were 283 manure-based biogas production plants in 2021 and Figure 10 represents the end-used biogas utilization systems according to their technologies between 2000 and 2021 [141]. As of 2017, there was a divergent increasing trend in numbers of pipeline and CNG biogas projects in the US. This may be due to legal regulations in 2016 and the widespread use of biogas as a fuel for agricultural purposes.

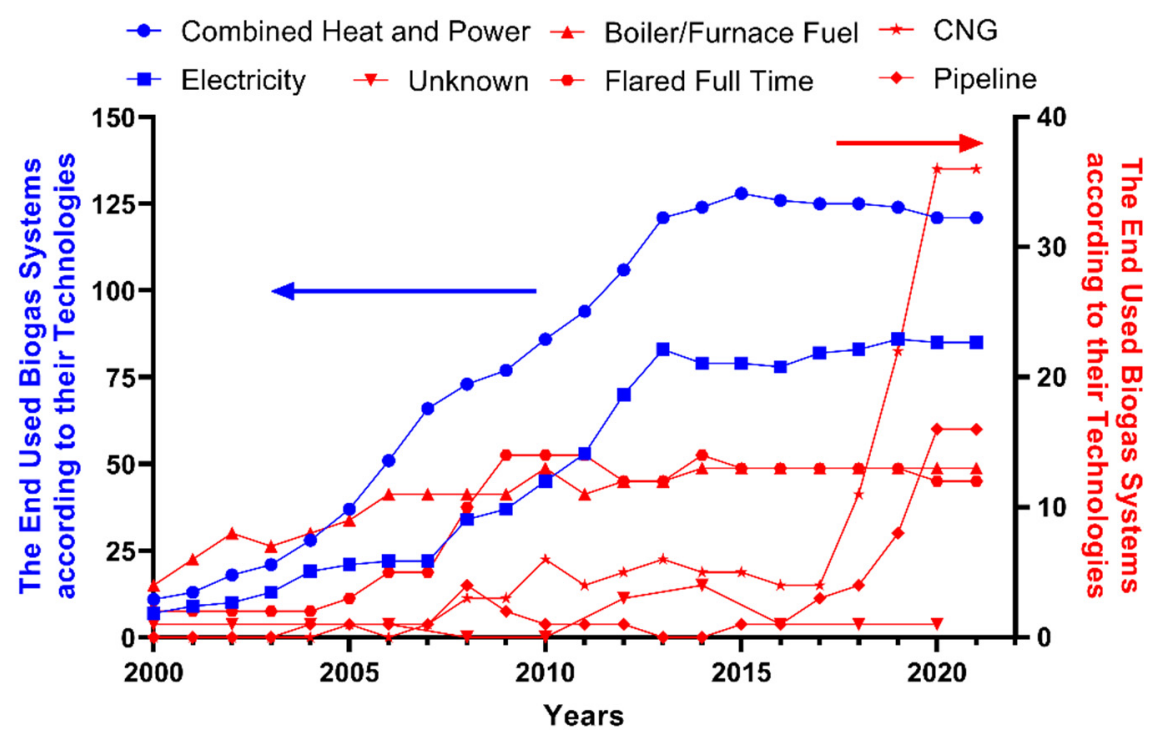

Figure 10. The end-used biogas utilization system according to their technologies in the US from 2000 to 2021 [141].

When producing electricity from biogas, different methods have different impacts on emission rates due to their combustion processes. For example, gas engines produce low emissions, while diesel engines which use ignition oil have high gas emissions in their exhaust fumes. Electricity production in engines of less than $100 \mathrm{~kW}$ has lower efficiency and a higher rate of exhaust gas emissions when compared with electricity production at higher than $300 \mathrm{~kW}$ [142]. It is clearly implied in the literature that biogas utilization for the production of electricity is much more environmentally friendly compared to electricity generation from fossil fuels.

Biogas can also be used as a hybrid with other renewable energy sources to stabilize energy systems such as alongside wind and solar [143]. Additionally, it has been utilized for cooking and lighting purposes for a long time in developing countries. In this section, the utilization of biogas and associated technologies will be reviewed. Biogas utilization pathways are represented in Figure 11.

\subsection{Boilers, Gas Engines and Gas Turbines}

Boilers are the most common way to produce heat from biogas, and internal combustion engines are the most commercialized process for power production from biogas at biogas power plants. Boiler efficiencies are between 75 and 85\% [144] for heat production from biogas. Typical boilers can be made suitable for biogas utilization with small modifications such as gas-airflow rates. The advantage of these boilers is that they are able to burn low-quality biogas [145]. Internal combustion engines, which are developed for natural gas, can be used for biogas without any modification. The four-stroke engines' capacities are between a few $\mathrm{kW}$ and $10 \mathrm{MW}$ and their lifetime is approximately 60,000 hours; however, their electrical efficiency is low, between 35 and $40 \%$ [42]. Their efficiency and antiknock properties are increased with a reduction in $\mathrm{CO}_{2}$ concentration in biogas [145]. The most common system for the production of power and heat simultaneously is known as com- 
bined heat and power (CHP) plants. In the EU, half of the biogas plants have CHP units, which are run with four-stroke engines, and half of these engines are diesel engines [42]. A modern CHP plant's heat and power efficiency is $85-90 \%$ [145]; however, the electrical efficiency is under $40 \%$ and only $2.4 \mathrm{kWh}$ of electricity can be produced when $1 \mathrm{~m}^{3}$ biogas is combusted [42]. In addition, gas turbines are used to produce electricity from biogas. Various capacities of gas turbines are available in the market, from $500 \mathrm{~kW}$ to $250 \mathrm{MW}$, and single-cycle gas turbine efficiencies are between $20-45 \%$ and their efficiency increases with the size [145]. The distinguishing feature of a gas turbine is low $\mathrm{NO}_{\mathrm{x}}$ emissions, which are less than $25 \mathrm{ppm}$ when the cleaned biogas is used [42].

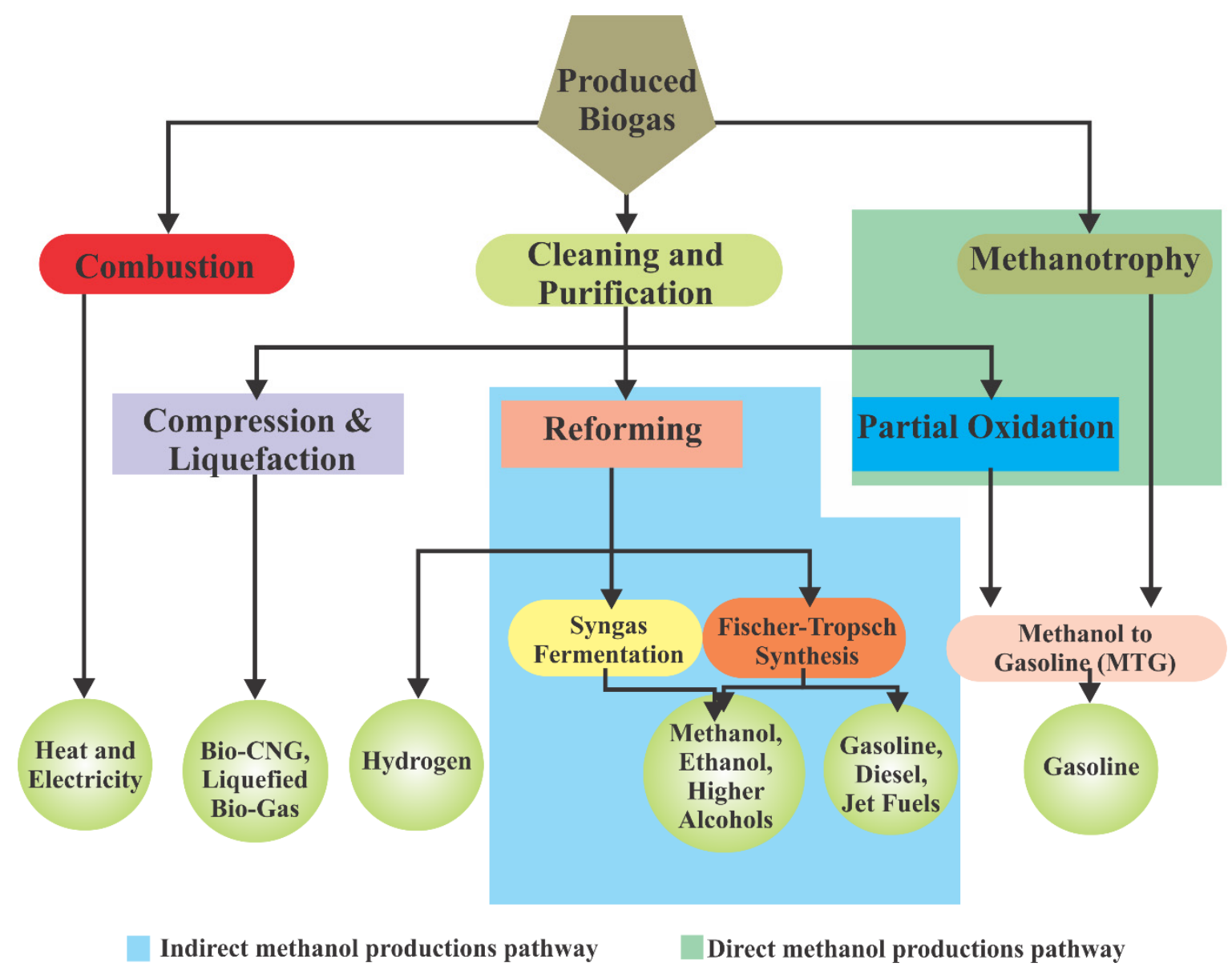

Figure 11. The schematic representation of biogas utilization pathways (adopted from [58]).

Using small-sized engines for the utilization of biogas is still problematic due to low efficiency [146]. Currently, the homogeneous charge compression ignition (HCCI) method has been heavily researched and has shown to be a promising technique. Saxane et al. [147] and Reitx et al. [148] made comprehensive reviews about HCCI technology and compared it with spark-ignited and diesel engines. HCCI uses low-temperature combustion which produces low $\mathrm{NO}_{\mathrm{x}}$ emissions. A study tested the HCCI thermal efficiency and found it to be around $50 \%$, which is close to diesel engine performance when diesel and biogas mixtures were used [149]. In fact, additional biogas in the fuel decreases thermal efficiency due to its low calorific value. Bedoya et al.'s [150] experimental study clearly showed that HCCI is a promising method to reach high thermal efficiencies of $44 \%$ and low $\mathrm{NO}_{\mathrm{x}}$ emissions of $0.11 \mathrm{~g} / \mathrm{kWh}$. Additionally, Blizman et al. [151] reported that $\mathrm{NO}_{\mathrm{x}}$ emissions were at the same level for landfill gases with the HCCI method. Another method for using biogas is flameless combustion. This method is able to increase biogas efficiency and also decreases particles and $\mathrm{NO}_{x}$ emissions. The study investigated biogas utilization using flameless 
combustion, and the results revealed that electrical efficiency was 53\% and CHP efficiency could reach $82 \%$ using exhausted gases for energy recovery with low $\mathrm{NO}_{\mathrm{x}}$ emissions which was around $2 \%$ of the volume of exhausted gases [152].

Innovative methods for the utilization of biogas include dual-fuel engines, stirling engines, and micro gas turbines. Dual-fuel engines use biogas by cofiring with very small amounts of biodiesel, bioethanol, or diesel [153]. Stirling engines convert thermal energy into mechanical energy; thus, they are theoretically perfect for producing electricity from waste thermal energy. The initial investment cost is still very high and their electrical efficiency is around 20\% [154]. Micro gas turbines are compact, operate at high speed, are low noise, and are vibration-free where gas turbines and their power range is between 25 and $500 \mathrm{~kW}$. If the methane content in biogas is higher than $30 \%$, the biogas can be used with a micro gas turbine [145]. Their electrical efficiency is higher than $45 \%$ [143].

In the literature, biogas and diesel in the dual-fuel mode in combustion ignition (CI) have been studied since 1980. Mathur et al. [155] used biogas as a biofuel in CI and Prakash et al. [156] improved a mathematical equation to predict the ignition delay of dual-fuel mode CI. Mustafi et al. [157] investigated dual-fuel mode $\mathrm{CI}$ with different $\mathrm{CH}_{4}$ and $\mathrm{CO}_{2}$ ratios of biogas and diesel. The results revealed that $70 \%$ of particulate matter $(\mathrm{PM})$ emissions and $37 \%$ of $\mathrm{NO}_{\mathrm{x}}$ emissions were reduced compared with diesel fuel when the biogas contained $70 \%$ of $\mathrm{CH}_{4}$ [157]. Cacue et al. [158] investigated the effect of enriched oxygen in the air and dual-fuel mode in $\mathrm{CI}$. They reported that increased $\mathrm{O}_{2}$ concentration in the air gave a positive impact on biogas and diesel dual-fuel mode for emission and brake thermal efficiency (BTE) according to the control group. BTE increased by $28 \%$ when the $\mathrm{O}_{2}$ concentration in the air reached 27\% [158]. Another comprehensive study focused on combustion characteristics and emissions in dual-fuel mode with different feeding ratios of biogas [159]. They used diesel and four different biogas feeding rates of 0.3, 0.6, 0.9, and $1.2 \mathrm{~kg} / \mathrm{h}$. The results represented that $14.8,26.6,36.9$, and $43.9 \%$ of energy could be met from biogas in dual-fuel mode at the full load when biogas flow rates were 0.3, 0.6, 0.9 , and $1.2 \mathrm{~kg} / \mathrm{h}$, respectively. Moreover, with a $1.2 \mathrm{~kg} / \mathrm{h}$ biogas feeding rate, the exhaust temperature and $\mathrm{NO}_{\mathrm{x}}$ were decreased by 14.2 and $42.8 \%$, respectively when compared with control fuel at full load [159]. Another study was focused on the exergy analysis of biogas and diesel fuel under the dual-fuel mode and the result revealed that exergy efficiency does not drop as energy efficiency does when biogas was used as a primary fuel [160]. Recently, Wang et al. [161] studied a reactivity-controlled compression ignition mode based on dualfuel combustion. In their report, the BTE could reach $40 \%$ in the optimal condition. Another promising development has occurred in fuel in recent years. This development is known as modified fuel, in which liquid fuels are mixed with nanoparticles. The nanoparticles act as combustion catalysts, especially with CI engines [162]. Diesel or biodiesel have been mixed with different nanoparticles, which are classified as metal, metal oxide, nanofluid, and carbon nanotubes [163]. However, additive nanoparticles give several advantages to fuels, and researchers have been generally focused on diesel and blending diesel and biodiesel fuels. In the literature, there is a huge gap to be filled regarding other biofuel resources such as modified fuels. Modified fuels can be used with biogas in dual-fuel mode. To the authors' best knowledge, only one group has been working on this topic. Feroskhan et al. [164] investigated a dual-fuel CI engine with fueled biogas and modified diesel. They modified diesel with 15,25 , and $35 \mathrm{ppm} \mathrm{CeO}_{2}$ as an additive material and they used this fuel with different biogas feeding rates in dual-fuel CI [164]. In their first study, modified diesel with 15 and $25 \mathrm{ppm} \mathrm{CeO}$ and $4 \mathrm{~L} / \mathrm{min}$ biogas feeding rate showed higher BTE than both diesel and modified diesel [165]. In their second study, they worked on the optimization of $\mathrm{CeO}_{2}$ concentration in dual-fuel mode $\mathrm{CI}$. Their results revealed that biogas and modified fuel with $25 \mathrm{ppm} \mathrm{CeO}_{2}$ reduced all emissions and increased BTE [164]. Table 5 shows the current studies with their key results. 
Table 5. Biogas utilization in the compression ignition engine with dual-fuel mode.

\begin{tabular}{|c|c|c|c|c|c|c|c|c|c|}
\hline Type of Fuel & $\begin{array}{l}\mathrm{CH}_{4} \\
(\%)\end{array}$ & $\begin{array}{c}\text { Compression } \\
\text { Rate }\end{array}$ & $\begin{array}{l}\text { Control } \\
\text { Fuel }\end{array}$ & $\begin{array}{l}\mathrm{NO}_{x} \\
(\%)\end{array}$ & $\begin{array}{l}\mathrm{HC} \\
(\%)\end{array}$ & $\begin{array}{l}\mathrm{CO} \\
(\%)\end{array}$ & $\begin{array}{l}\text { Smoke } \\
(\%)\end{array}$ & $\begin{array}{l}\text { BTE } \\
(\%)\end{array}$ & Refs. \\
\hline $\begin{array}{l}\text { Biogas-Biodiesel- } \\
\text { DEE }\end{array}$ & 90.6 & $16.5-18.5$ & Biodiesel & $\uparrow 7.6$ & $\downarrow 39.5$ & $\downarrow 42.2$ & $\downarrow 42.8$ & $\uparrow 7$ & [166] \\
\hline $\begin{array}{l}\text { Biodiesel-Biogas } \\
\text { Dual Fuel }\end{array}$ & 73 & 17.5 & Biodiesel & $\uparrow 5.5$ & $\downarrow 18.2$ & $\downarrow 17.1$ & $\downarrow 2.1$ & $\uparrow 6.6$ & [167] \\
\hline $\begin{array}{c}\text { Simulated } \\
\text { Biogas-Biodiesel }\end{array}$ & $30-40-50$ & 19.5 & Biodiesel & $\downarrow 80 *$ & $\uparrow 96^{*}$ & $\uparrow 92 *$ & - & $\downarrow 32.6$ & [153] \\
\hline $\begin{array}{c}\text { Diesel, WCOME + } \\
\text { Biogas }\end{array}$ & 71 & 17.5 & Diesel & $\uparrow 6.1-8.9$ & $\begin{array}{l}\downarrow 14.8- \\
44.4\end{array}$ & $\begin{array}{l}\uparrow 21.4- \\
29.8\end{array}$ & $\uparrow 2.3-3.4$ & $\downarrow 9.7$ & [168] \\
\hline $\begin{array}{l}55-85^{\circ} \mathrm{C} \text { Preheated } \\
\text { Biogas-Air Mixture }\end{array}$ & 70 & 17.2 & $\begin{array}{c}\text { non- } \\
\text { preheated } \\
\text { mixture }\end{array}$ & $\uparrow 11.73$ & $\underset{*}{\uparrow 150-250}$ & $\uparrow 6-371$ * & - & $\uparrow 51.4$ & [169] \\
\hline $\begin{array}{l}\text { Diesel-Purified } \\
\text { Biogas }\end{array}$ & 70.4-93.8 & 17.2 & Diesel & - & - & $\downarrow 10-50$ * & - & $\downarrow 10-15^{*}$ & [170] \\
\hline $\begin{array}{c}\text { Diesel-Biogas-10- } \\
20 \% \mathrm{H}_{2}\end{array}$ & 70 & 18 & Diesel & $\uparrow 6$ & $\downarrow 25$ & $\downarrow 30$ & - & $\uparrow 32$ & [171] \\
\hline Diesel-Biogas- $\mathrm{H}_{2}$ & $48-80$ & 20 & $\begin{array}{l}\text { Direct and } \\
\text { indirect } \\
\text { injection } \\
\text { condition }\end{array}$ & $\uparrow 150$ & & $\downarrow 20$ & $\begin{array}{l}\text { No } \\
\text { change }\end{array}$ & $\uparrow 6$ & [172] \\
\hline
\end{tabular}

${ }^{*}$ was calculated from the paper data. $\uparrow$ was increase, $\downarrow$ was decrease.

Biogas can be easily used in spark ignition (SI) engines due to mixing with gasoline, after which it can be fed into the cylinder, while dual-fuel mode has to be used for compression ignition with mixing air. A study reported that when the biogas was used with a spark engine with a compression ratio of 10 and a BSFC increased by $66 \%$ while BTE, CO and $\mathrm{NO}_{x}$, emissions were reduced by $12 \%, 40 \%$, and $81.5 \%$, respectively, compared to fueling with gasoline [173]. Another study investigated the compression ratios of SI in the range of 6 to 9 [174]. The results revealed that the power obtained from the test engine fueled with biogas was increased by $13.4 \%$ and BSFC was decreased by $18.18 \%$ when the compression ratio was 8 [174]. A similar study reported the same finding for the compression ratio of SI. When ethanol and biogas were used, $\mathrm{HC}, \mathrm{CO}$, and $\mathrm{NO}_{\mathrm{x}}$ emissions were decreased while BTE was increased [175]. Table 6 represents the findings of the recent studies when biogas was used as a fuel in an SI engine.

Table 6. Biogas utilization in the spark ignition engine.

\begin{tabular}{|c|c|c|c|c|c|c|c|c|}
\hline Type of Fuel & $\begin{array}{l}\mathrm{CH}_{4} \\
(\%)\end{array}$ & $\begin{array}{l}\text { Compression } \\
\text { Rate (CR) }\end{array}$ & $\begin{array}{c}\text { Control } \\
\text { Fuel }\end{array}$ & $\begin{array}{c}\mathrm{NO}_{\mathrm{x}} \\
(\%)\end{array}$ & $\begin{array}{l}\mathrm{HC} \\
(\%)\end{array}$ & $\begin{array}{l}\mathrm{CO} \\
(\%)\end{array}$ & $\begin{array}{l}\text { BTE } \\
(\%)\end{array}$ & Refs. \\
\hline Gasoline+Biogas & 55.6 & 10 & Gasoline & $\downarrow 81.5$ & $\uparrow 6.8$ & $\downarrow 40$ & $\downarrow 12$ & [173] \\
\hline Simulated Biogas & 60 & 12 & $100 \% \mathrm{CH}_{4}$ & $\downarrow 71.74$ & - & - & - & [176] \\
\hline Biogas-Ethanol & 64.96 & 13.6 & Ethanol & $\downarrow 30$ & $\downarrow 60$ & $\downarrow 50$ & $\uparrow 20$ & [175] \\
\hline Syngas-Biogas & $4-65$ & 12.9 & Biogas & $\downarrow 5$ & - & - & $\uparrow 3$ & [177] \\
\hline Biogas & 55.6 & $10-12$ & $\begin{array}{c}\text { Biogas from } 10 \text { to } \\
12 \mathrm{CR}\end{array}$ & $\uparrow 10.17$ & $\uparrow 15.6$ & $\uparrow 0.01-0.258$ & $\uparrow 26.69-30.32$ & [178] \\
\hline Biogas & 55.6 & 10 & $\begin{array}{l}\text { Biogas from } 33 \text { to } \\
47^{\circ} \mathrm{C} \text { A ignition } \\
\text { advance }\end{array}$ & $\downarrow 88$ & $\downarrow 40$ & $\uparrow 50 *$ & $\downarrow 13^{*}$ & [179] \\
\hline Gasoline-Biogas-LPG & 55.6 & 8 & Gasoline & $\downarrow 50.09$ & $\downarrow 23$ & $\downarrow 15$ & $\downarrow 16.04$ & [180] \\
\hline $\begin{array}{l}\text { Different ratio of } \\
\text { Hydroxy and Biogas }\end{array}$ & 70 & 8.5 & $\begin{array}{l}\text { Ratio of Hydroxy } \\
\text { and Biogas }\end{array}$ & 1192 ppm & - & $0.74 \%$ & $204 \mathrm{~J} /$ cycle & [181] \\
\hline
\end{tabular}

${ }^{*}$ was calculated from the paper data. $\uparrow$ was increase, $\downarrow$ was decrease. 


\subsection{Fuel Cells}

One of the most efficient ways to generate electricity using biogas is through a fuel cell. The method uses an electrochemical reaction where oxygen and hydrogen atoms react to produce energy and water. The fuel cell has an anode and cathode that are separated from each other with a nonconductive solid or liquid electrolyte. Fuel flows through the anode and oxygen goes through the cathode. The ions, which are produced at the anode, are able to pass through the electrolyte; however, the electrons pass through an external circuit and generate electricity [145]. Fuel cells are a relatively new technology with high efficiency and low emissions as reviewed by Alves et al. [182] and Bocci et al. [183]. Biogas utilization with fuel cells requires fuel purification and a cleaning process depending on fuel cell types. Therefore, biogas is more challenging than natural gas to use as a fuel. Additionally, another drawback of the fuel cells is their relatively high operating temperature, which depends on the type of fuel cell used. There are generally three different fuel cell types which utilize biogas.

\subsubsection{Solid Oxide Fuel Cells}

Solid Oxide Fuel Cells (SOFCs) are made of solid oxide or ceramic materials. This method has recently gained much attention. Ni-based material is generally used as an anode without deterioration of the fuel cell because it is cheap [184]. However, the fuel cell performance has a close relationship with impurities in biogas, especially $\mathrm{H}_{2} \mathrm{~S}$. Directly feeding biogas to SOFC is a heavily studied subject both experimentally [184-189], and with modeling [190,191]. Shiratori et al. [189] reported that Ni-ScSZ cermet was used as an anode material at $1000{ }^{\circ} \mathrm{C}$ operating temperature, and they achieved a cell voltage above $0.9 \mathrm{~V}$ after cleaning the $\mathrm{H}_{2} \mathrm{~S}$ in biogas. Moreover, they demonstrated that SOFC can tolerate $\mathrm{H}_{2} \mathrm{~S}$ impurity up to $1 \mathrm{ppm}$. Another study claimed that there is not any significant degradation after $\mathrm{H}_{2} \mathrm{~S}$ removal and the biogas can be used as a fuel for electricity generation with SOFC [188]. To decrease impurities in biogas, air can be added into biogas with no significant changes in the output voltage [143].

The system can work under either intermediate $\left(600-800{ }^{\circ} \mathrm{C}\right)[184,187]$ or high $\left(800-1000{ }^{\circ} \mathrm{C}\right)$ [189] temperature conditions. The temperature is a significant parameter for SOFC because electrochemical reactions are fast above $600{ }^{\circ} \mathrm{C}$ [46]. In addition, Ma et al. [187] reported that biogas is more suitable than $\mathrm{H}_{2}$ due to carbon degradation.

SOFC-based power-plant efficiency was estimated to be $74 \%$ when the method of partial oxidation reforming of the biogas was used [192]. Additionally, the efficiency can reach $80.5 \%$ with a heat recovery system. SOFC thermoeconomic analysis showed that pressurized SOFC can be more economical and can have a $25 \%$ lower electricity cost at 20 bars of pressure [193].

\subsubsection{Proton Exchange Membrane Fuel Cells}

Proton Exchange Membrane Fuel Cells (PEMFCs) run at a relatively low temperature and pressure compared to SOFCs. Their temperature and pressure range is between 50 and $100^{\circ} \mathrm{C}$, and 1 and 2 bars, respectively [194]. This fuel cell requires clean, hydrogen-rich fuel; therefore, it is not suitable for biogas utilization. Gual et al. [195] modeled biogas utilization with PEMFC. According to their results, electrical efficiency was $40 \%$ and the whole system efficiency reached $82 \%$ when the fuel cell was combined with CHP. Schmersahl et al. [194] studied PEMPC experimentally. They claimed that its performance was lower with biogas rather than natural gas. However, its efficiency was still higher than internal combustion engines. Another study confirmed their result with their model [196]. This study calculated that the electrical efficiency of PEMFC is around $40 \%$.

\subsubsection{Molten Carbonate Fuel Cells}

Molten Carbonate Fuel Cells (MCFC) are made of porous nickel electrodes and molten carbonate salt. This fuel cell has several advantages such as using different fuel sources, high efficiency, and low environmental impacts. The operating temperature is $600-700{ }^{\circ} \mathrm{C}$ 
and $\mathrm{CO}$ can be used as a fuel; however, $\mathrm{H}_{2} \mathrm{~S}$ has to be cleaned [197]. The first MCFC plant was built in the US in 1996 and was running with natural gas. It produced $2 \mathrm{MW}$ of electricity with $43.6 \%$ efficiency [198].

Trogisch et al. [199] studied MCFC with different biogas sources and they achieved $50 \%$ electrical efficiency. Another study focused on the $\mathrm{H}_{2} \mathrm{~S}$ toleration level of MCFC [200]. They suggested that sulphur-tolerant materials should be used in MCFC. Lanzini et al. [201] reviewed SOFC and MCFC plants and the effects of biogas containing significant impurities. All in all, MCFC needs further investigation to be commercialized.

\subsection{Biomethane}

Biomethane is almost equivalent to natural gas; therefore, it could be used for the transportation sector and for direct injection to gas grids. As mentioned in the previous section, raw biogas can be upgraded to biomethane by separating out $\mathrm{CO}_{2}$ and other impurities. If raw biogas is upgraded to higher than $\sim 95 \% \mathrm{CH}_{4}$, it can be directly injected into the gas grid and used as a vehicle fuel. In comparison to other countries, Sweden has best-utilized biogas as vehicle fuel. They have more than 36,000 vehicles on the road in 2011 that are running on biogas which can be refueled at 500 filling stations all over the country [202,203]. Another efficient way to use biomethane is to directly inject it into gas grids, because utilization of biogas at or near to production facilities is not feasible. Biomethane can be transferred through a large energy-demanding area with gas grids. Additionally, the separation of $\mathrm{CO}_{2}$ and $\mathrm{CH}_{4}$ can convert biogas into hydrogen-rich biogas via synthesis technology from Fischer-Tropsch [58]. Additionally, $\mathrm{CO}_{2}$ can be transformed into $\mathrm{CH}_{4}$, known as methanation through the Sabatier pathway [46]. Methanol production is able to pressurize $\mathrm{CO}_{2}$ with hydrogen under 20 bars of pressure. In the literature, hydrogen is obtained from water through electrolysis using renewable energy resources such as wind or solar power for obtaining $\mathrm{CH}_{4}$-rich biogas $[95,204]$.

\subsection{Biosyngas and Biohydrogen}

Biogas can be used for the production of biosyngas with a reforming process. Catalytic reforming including partial oxidation reforming with a metal catalyst such as platinum (Pt), palladium (Pd), nickel (Ni), cobalt (Co) and iron (Fe) has been studied [205,206]. Although the catalytic reforming process is possible, biogas is not well suitable for this process because of the poisoning of the catalysts and a significantly increased production price. A gliding arc reactor was used to produce biosyngas. Tu et al.'s [207] experimental study showed that $\mathrm{CH}_{4}$ and $\mathrm{CO}_{2}$ were reformed into $31 \% \mathrm{H}_{2}$-rich gases, and they claimed that a lower feeding gas flow allowed more hydrogen and carbon monoxide production and less hydrocarbon production. In addition, a tri-reforming process was studied for biogas utilization and their results showed high hydrogen yields, which were between $59.5 \%$ and $73.5 \%$ [208].

\subsection{Biomethanol, Bioethanol and Higher Alcohols}

Methanol can be used as a vehicle fuel. It can be converted to gasoline via a methanolto-gasoline process by catalytic conversion of syngas to methanol. Methanol has recently been produced from biomass using a biomass gasification process. In 2012, 200,000 tons of biomethanol was produced from biomass [209]. Biogas is also able to convert into methanol through processes such as oxidation of methane, photocatalytic conversion, biological conversion, and an indirect pathway, which reforms biogas and then methanol synthesis occurs. Methanol production has been reviewed by Park et al. [210]. Partial oxidation of methane is a well-established and the most widely used pathway to convert biogas to methanol. The process requires high pressure, which is between $0.5-15 \mathrm{MPa}$, or high temperature, which is between 700 and $750{ }^{\circ} \mathrm{C}$, to reach high yield [58]. Hydroxyl radicals are used to produce methanol with a photocatalytic conversion pathway. Hydroxyl radicals react to $\mathrm{CH}_{4}$, and methyl radicals are produced. When these radicals and water molecules react, methanol and hydrogen are produced as a final product [211]. With a biological pathway, 
the bacteria use methane and ammonia to produce methanol [211]. Recently, Su et al. [212] achieved $0.33 \mathrm{~g} / \mathrm{L}$ of methanol production with a biological methanol production pathway and a methanol conversion ratio of $0.47 \mathrm{~mol} \mathrm{methanol} / \mathrm{mol}$ methane.

Bioethanol and higher alcohols produced from biogas is a relatively new topic and has gained attention due to its energy density and low carbon and particulate matter emissions. Ethanol blend fuels have been used in the US; however, direct bioethanol and higher alcohols produced from biogas are still under research and development. With the catalytic approach patented by Exxon, $\mathrm{CH}_{4}$ is able to convert into ethanol and methanol directly [58]. For this method, $\mathrm{Fe}_{2}\left(\mathrm{SO}_{4}\right)_{3}$ or $\mathrm{Fe}\left(\mathrm{ClO}_{4}\right)_{3}$ were used to produce ethanol and methanol and different noble materials have been investigated for this method [58]. However, an availability date is not contained in the literature.

Another method to produce ethanol and higher alcohols is a two-step approach. The first one is to reform biogas to syngas, and the next step is to convert syngas into ethanol and higher alcohols. The second step can take place in biological or catalytic conversion. With biological conversion, bacteria use the acetyl-CoA path. The reaction depends on the $\mathrm{H}_{2}$ to $\mathrm{CH}_{4}$ ratio. This method is a promising way to produce ethanol and higher alcohols in an ambient environment with no potential metal poisoning [58]. The yield of ethanol production from syngas was reported at $48 \mathrm{~g} / \mathrm{L}$ [213]. With the catalytic conversion method, the reaction is an alternative way to produce ethanol and higher alcohols. The operating conditions require pressure and temperature of around $20 \mathrm{MPa}$ and $300-400{ }^{\circ} \mathrm{C}$, respectively [58].

\section{Conclusion and Future Trend of Biogas}

Biogas production from anaerobic digestion processes has gained great attention during the last two decades because of its many positive benefits, which include it being a low energy-demand process, it generating relatively low sludge production for disposal, and it being a form of renewable energy. Additionally, this process is key to make the best use of wastes and to obtain energy. The production of biogas with a well-optimized system is not the only difficulty, but upgrading the biogas quality is also necessary for it to meet certain requirements so it can be used instead of fossil fuels. Cleaning and upgrading technologies are currently being heavily studied. However, there is a lack of information available such as for commercial-scale applications including economic and environmental information. The cleaning and upgrading processes require high energy use and the input of additional chemicals. According to the results of this survey, the amine-scrubbing method appears to be more beneficial than other methods because of lower methane losses, lower energy demand, and higher final methane content.

Additionally, the removal of $\mathrm{CO}_{2}$, which is the second main product of biogas, and the removal of $\mathrm{H}_{2} \mathrm{~S}$, has been investigated with a novel approach using microalgae. Although it has some issues that need to be overcome such as $\mathrm{O}_{2}$ concentration during upgrading, it could be commonly used soon in commercial applications. However, biological methods are relatively new compared to other techniques but appear to be advantageous in terms of overall feasibility and advantages. The development of biological upgrade technologies may occur quickly once the identified challenges are overcome.

Another promising upgrading method is the membrane technique, due to economic and environmental concerns. In the literature, researchers have generally focused on reducing methane losses; however, the membrane material compatibility and improvement of resistance with different impurities in raw biogas should be be investigated in future research. New membrane materials and theories are still under development and are being tested in labs. The pilot systems should be applied and would fill the gap between lab-scale and large-scale systems. Additionally, in situ production and upgrading reactor design should be studied more to gain additional information and to be able to apply them to large-scale systems.

Biogas can be used as an energy source in different kinds of applications such as heat, vehicle fuels, gas-grid injection, biochemical production, and higher alcohols; however, 
the cleaning and upgrading process is necessary for methane purification. The maximum energy could be obtained from biogas using a combined heat and power system. Moreover, there is a notable finding for internal combustion engines when adding nanoparticles which both reduces the harmful exhaust emissions and improves the engine performance when the engine is fueled with biogas under dual-fuel mode. Researchers should focus on this area to reveal the benefits and drawbacks.

Overall, biogas production and utilization are a great and promising pathway to reduce mankind's negative impacts on the environment and may reduce dependence on fossil fuels. Policymakers have to think about the underutilized significant potential of biogas production and increase their support for biogas utilization. With their support and researchers' efforts, biogas can be a significant solution towards a reduction in greenhouse gas emissions, the production of renewable energy, and the management of waste disposal.

Author Contributions: Writing—original draft preparation, M.R.A., H.S., M.D., T.A.H. and D.K.; writing-review and editing A.A., M.R.A., C.E., H.M., S.U., S.K., N.A., H.D.K.; supervision A.A., C.E., N.A., H.D.K. All authors have read and agreed to the published version of the manuscript.

Funding: This research received no external funding.

Conflicts of Interest: All the authors declare no conflict of interest.

\section{Nomenclature}

\begin{tabular}{|c|c|c|c|}
\hline BTE & Brake thermal efficiency & $\mathrm{HClO}_{3}$ & Chloric acid \\
\hline $\mathrm{CH}_{4}$ & Methane & LNG & Liquefied renewable natural gas \\
\hline $\mathrm{CHP}$ & Combined heat and power & TSA & Temperature swing adsorption \\
\hline CI & Combustion ignition & $\mathrm{H}_{2} \mathrm{SO}_{4}$ & Sulphuric acid \\
\hline $\mathrm{Cl}_{2} \mathrm{O}$ & Dichlorine monoxide & PSA & Pressure swing adsorption \\
\hline $\mathrm{CO}_{2}$ & Carbon dioxide & $\mathrm{Cl}_{2}$ & Chlorine \\
\hline $\mathrm{H}_{2}$ & Hydrogen & EBA & European biomass association \\
\hline $\mathrm{H}_{2} \mathrm{~S}$ & Hydrogen sulfide & $\mathrm{HClO}$ & Hypochlorous acid \\
\hline \multirow[t]{2}{*}{$\mathrm{HCCI}$} & Homogeneous charge & & \\
\hline & compression ignition & CA & Cellulose acetate \\
\hline HPWS & High-pressure water washing & ESA & Electrical swing adsorption \\
\hline $\mathrm{N}_{2}$ & Nitrogen & $\mathrm{CNG}$ & Compressed renewable natural gas \\
\hline $\mathrm{N}_{2} \mathrm{O}$ & Nitrous oxide & $\mathrm{HF}$ & Hydrofluoric acid \\
\hline $\mathrm{NaNO}_{3}$ & Sodium nitrate & $\mathrm{HCl}$ & Hydrochloric acid \\
\hline $\mathrm{NO}_{3}{ }^{-}$ & Nitrate ions & $\mathrm{CO}$ & Carbon monoxide \\
\hline $\mathrm{O}_{2}$ & Oxygen & $\mathrm{SO}_{2}$ & Sulfur dioxide \\
\hline PM & Particulate matter & $\mathrm{NaOH}$ & Sodium hydroxide \\
\hline SI & Spark ignition & PEMFCs & Proton exchange membrane fuel cells \\
\hline SOFCs & Solid oxide fuel cells & MCFCs & Molten carbonate fuel cells \\
\hline VFAs & Volatile fatty acids & WWTP & Wastewater treatment plants \\
\hline VOCs & Volatile organic compounds & VMS & Volatile methyl siloxanes \\
\hline VSC & Volatile sulfur compounds & VOCs & Volatile organic compounds \\
\hline $\mathrm{Ca}(\mathrm{OH})_{2}$ & Calcium hydroxide & & \\
\hline
\end{tabular}

\section{References}

1. D'Adamo, I.; Morone, P.; Huisingh, D. Bioenergy: A Sustainable Shift. Energies 2021, 14, 5661. [CrossRef]

2. Busu, M. Assessment of the Impact of Bioenergy on Sustainable Economic Development. Energies 2019, 12, 578. [CrossRef]

3. Alsaleh, M.; Abdulwakil, M.; Abdul-Rahim, A. Does Social Businesses Development Affect Bioenergy Industry Growth under the Pathway of Sustainable Development? Sustainability 2021, 13, 1989. [CrossRef]

4. Pehlken, A.; Wulf, K.; Grecksch, K.; Klenke, T.; Tsydenova, N. More Sustainable Bioenergy by Making Use of Regional Alternative Biomass? Sustainability 2020, 12, 7849. [CrossRef]

5. Fu, S.; Angelidaki, I.; Zhang, Y. In situ Biogas Upgrading by $\mathrm{CO}_{2}$-to- $\mathrm{CH}_{4}$ Bioconversion. Trends Biotechnol. $2020,39,336-347$. [CrossRef] [PubMed]

6. Buffiere, P.; Germain, R.B.P. Freins et Développements de la Filière Biogaz: Les Besoins en Recherche et Développement. Available online: https:/ /inis.iaea.org/collection/NCLCollectionStore/_Public/47/106/47106366.pdf (accessed on 12 October 2021). 
7. Atelge, M.R.; Krisa, D.; Kumar, G.; Eskicioglu, C.; Nguyen, D.D.; Chang, S.W.; Atabani, A.E.; Al-Muhtaseb, A.H.; Unalan, S. Biogas Production from Organic Waste: Recent Progress and Perspectives. Waste Biomass Valorization 2020, 11, 1019-1040. [CrossRef]

8. Deublein, D.; Steinhauser, A. Biogas from Waste and Renewable Resources; Wiley: Hoboken, NJ, USA, 2008.

9. Boulinguiez, B.; Le cloirec, P. Purification de biogaz. Élimination des COV et des siloxanes. Tech. L'ingénieur 2011, 33, 1-26.

10. Demirbas, A.; Taylan, O.; Kaya, D. Biogas production from municipal sewage sludge (MSS). Energy Sources Part A Recovery Util. Environ. Eff. 2016, 38, 3027-3033. [CrossRef]

11. Atelge, M.R.; Atabani, A.E.; Banu, J.R.; Krisa, D.; Kaya, M.; Eskicioglu, C.; Kumar, G.; Lee, C.; Yildiz, Y.Ş.; Unalan, S.; et al. A critical review of pretreatment technologies to enhance anaerobic digestion and energy recovery. Fuel 2020, $270,117494$. [CrossRef]

12. Baena-Moreno, F.M.; Rodríguez-Galán, M.; Vega, F.; Vilches, L.F.; Navarrete, B. Review: Recent advances in biogas purifying technologies. Int. J. Green Energy 2019, 16, 401-412. [CrossRef]

13. Wellinger, A.; Jerry, M.; Baxter, D. The Biogas Handbook: Science, Production and Applications; Elsevier: Amsterdam, The Netherlands, 2013; pp. 1-476.

14. Gerardi, M.H. The microbiology of anaerobic digesters. In Wastewater Microbiology Series A; John Wiley \& Sons. Inc.: Piscataway, NJ, USA, 2003.

15. Paolini, V.; Petracchini, F.; Carnevale, M.; Gallucci, F.; Perilli, M.; Esposito, G.; Segreto, M.; Occulti, L.G.; Scaglione, D.; Ianniello, A.; et al. Characterisation and cleaning of biogas from sewage sludge for biomethane production. J. Environ. Manag. 2018, 217, 288-296. [CrossRef]

16. Kapoor, R.; Ghosh, P.; Tyagi, B.; Vijay, V.K.; Vijay, V.; Thakur, I.S.; Kamyab, H.; Nguyen, D.D.; Kumar, A. Advances in biogas valorization and utilization systems: A comprehensive review. J. Clean. Prod. 2020, 273, 123052. [CrossRef]

17. Kapoor, R.; Ghosh, P.; Kumar, M.; Vijay, V.K. Evaluation of biogas upgrading technologies and future perspectives: A review. Environ. Sci. Pollut. Res. 2019, 26, 11631-11661. [CrossRef]

18. Zheng, L.; Cheng, S.; Han, Y.; Wang, M.; Xiang, Y.; Guo, J.; Cai, D.; Mang, H.P.; Dong, T.; Li, Z.; et al. Bio-natural gas industry in China: Current status and development. Renew. Sustain. Energy Rev. 2020, 128, 109925. [CrossRef]

19. Angelidaki, I.; Treu, L.; Tsapekos, P.; Luo, G.; Campanaro, S.; Wenzel, H.; Kougias, P.G. Biogas upgrading and utilization: Current status and perspectives. Biotechnol. Adv. 2018, 36, 452-466. [CrossRef] [PubMed]

20. Deng, L.; Liu, Y.; Wang, W. Biogas Cleaning and Upgrading. In Biogas Technology; Deng, L., Liu, Y., Wang," W., Eds.; Springer: Singapore, 2020; pp. 201-243.

21. Ryckebosch, E.; Drouillon, M.; Vervaeren, H. Techniques for transformation of biogas to biomethane. Biomass Bioenergy 2011, 35, 1633-1645. [CrossRef]

22. Garnaik, P.P.; Pradhan, R.R.; Chiang, Y.W.; Dutta, A. Biomass-Based $\mathrm{CO}_{2}$ Adsorbents for Biogas Upgradation with Pressure Swing Adsorption. In Climate Change and Green Chemistry of $\mathrm{CO}_{2}$ Sequestration, Green Energy and Technology; Goel, M., Satyanarayana, T., Sudhakar, M., Agrawal, D.P., Eds.; Springer: Singapore, 2021.

23. Struk, M.; Kushkevych, I.; Vítězová, M. Biogas upgrading methods: Recent advancements and emerging technologies. Rev. Environ. Sci. Biotechnol. 2020, 19, 651-671. [CrossRef]

24. Awe, O.W.; Zhao, Y.; Nzihou, A.; Minh, D.P.; Lyczko, N. A Review of Biogas Utilisation, Purification and Upgrading Technologies Review. Waste Biomass Valorization 2017, 8, 267-283. [CrossRef]

25. Savickis, J.; Zemite, L.; Zeltins, N.; Bode, I.; Jansons, L.; Dzelzitis, E.; Koposovs, A.; Selickis, A.; Ansone, A. The biomethane injection into the natural gas networks: The EU's gas synergy path. Latv. J. Phys. Tech. Sci. 2020, 57, 34-50. [CrossRef]

26. Hakawati, R.; Smyth, B.M.; Rosa, F.D.; Rooney, D. What is the most energy efficient route for biogas utilization: Heat, electricity or transport? Appl. Energy 2017, 206, 1076-1087. [CrossRef]

27. Chang, I.S.; Zhao, J.; Yin, X.; Wu, J.; Jia, Z.; Wang, L. Comprehensive utilizations of biogas in Inner Mongolia, China. Renew. Sustain. Energy Rev. 2011, 15, 1442-1453. [CrossRef]

28. Deng, L.; Liu, Y.; Wang, W. Biogas Utilization. In Biogas Technology; Springer: Singapore, 2020; Volume 8, pp. 269-318.

29. Sun, Q.; Li, H.; Yan, J.; Liu, L.; Yu, Z.; Yu, X. Selection of appropriate biogas upgrading technology-a review of biogas cleaning, upgrading and utilisation. Renew. Sustain. Energy Rev. 2015, 51, 521-532. [CrossRef]

30. IRENA. Renewable Energy Statistics 2019; The International Renewable Energy Agency: Abu Dhabi, United Arab Emirates, 2019.

31. IRENA. Renewable Energy Statistics 2021; The International Renewable Energy Agency: Abu Dhabi, United Arab Emirates, 2021.

32. Igliński, B.; Piechota, G.; Iwański, P.; Skarzatek, M.; Pilarski, G. 15 Years of the Polish agricultural biogas plants: Their history, current status, biogas potential and perspectives. Clean Technol. Environ. Policy 2020, 22, 281-307. [CrossRef]

33. Schmid, C.; Horschig, T.; Pfeiffer, A.; Szarka, N.; Thrän, D. Schmid; Horschig; Pfeiffer; Szarka; Thrän, Biogas Upgrading: A Review of National Biomethane Strategies and Support Policies in Selected Countries. Energies 2019, 12, 3803. [CrossRef]

34. D'Adamo, I.; Falcone, P.M.; Huisingh, D.; Morone, P. A circular economy model based on biomethane: What are the opportunities for the municipality of Rome and beyond? Renew. Energy 2021, 163, 1660-1672. [CrossRef]

35. Herbes, C. Marketing of Biomethane; Springer: Cham, Switzerland, 2017; pp. 151-171.

36. Rodenhizer, J.S.; Boardman, G.D. Collection, Analysis, and Utilization of Biogas from Anaerobic Treatment of Crab Processing Waters. J. Aquat. Food Prod. Technol. 1999, 8, 59-75. [CrossRef] 
37. Chandra, R.; Isha, A.; Kumar, S.; Khan, S.A.; Subbarao, P.M.V.; Vijay, V.K.; Chandel, A.K.; Chaudhary, V.P. Potentials and Challenges of Biogas Upgradation as Liquid Biomethane. In Biogas Production; Balagurusamy, N., Chandel, A.K., Eds.; Springer: Cham, Switzerland, 2020; pp. 307-328.

38. Atelge, M.R.; Atabani, A.E.; Abut, S.; Kaya, M.; Eskicioglu, C.; Semaan, G.; Lee, C.; Yildiz, Y.Ş.; Unalan, S.; Mohanasundaram, R.; et al. Anaerobic co-digestion of oil-extracted spent coffee grounds with various wastes: Experimental and kinetic modeling studies. Bioresour. Technol. 2021, 322, 124470. [CrossRef] [PubMed]

39. Lahbab, A.; Djaafri, M.; Kalloum, S.; Benatiallah, A.; Atelge, M.R.; Atabani, A.E. Co-digestion of vegetable peel with cow dung without external inoculum for biogas production: Experimental and a new modelling test in a batch mode. Fuel 2021, 306, 121627. [CrossRef]

40. Bora, D.; Barbora, L.; Borah, A.J.; Mahanta, P. A Comparative Assessment of Biogas Upgradation Techniques and Its Utilization as an Alternative Fuel in Internal Combustion Engines. In Alternative Fuels and Advanced Combustion Techniques as Sustainable Solutions for Internal Combustion Engines. Energy, Environment, and Sustainability; Singh, A.P., Kumar, D., Agarwal, A.K., Eds.; Springer: Singapore, 2021.

41. Braun, R. Anaerobic digestion: A multi-faceted process for energy, environmental management and rural development. Improvement of Crop Plants for Industrial End Uses; Springer: Dordrecht, The Netherlands, 2007; pp. 335-416.

42. Deublein, D.; Steinhauser, A. Biogas from Waste and Renewable Resources: An Introduction, 2nd ed.; John Wiley \& Sons: Piscataway, NJ, USA, 2011.

43. Hassaan, M.A.; El Nemr, A.; Elkatory, M.R.; Ragab, S.; El-Nemr, M.A.; Pantaleo, A. Synthesis, Characterization, and Synergistic Effects of Modified Biochar in Combination with $\alpha$-Fe2O3 NPs on Biogas Production from Red Algae Pterocladia capillacea. Sustainability 2021, 13, 9275. [CrossRef]

44. Felipe, I.; Barros, R.M.; Lucio, G.; Filho, T. Electricity generation from biogas of anaerobic wastewater treatment plants in Brazil: An assessment of feasibility and potential. J. Clean. Prod. 2016, 126, 504-514.

45. Kumara Behera, B.; Varma, A. Chapter 2: Biomethanization. In Microbial Resources for Sustainable Energy; Springer: Cham, Switzerland, 2016; pp. 35-122.

46. Yentekakis, I.V.; Goula, G. Biogas Management: Advanced Utilization for Production of Renewable Energy and Added-value Chemicals. Front. Environ. Sci. 2017, 5, 7. [CrossRef]

47. Chen, X.; Yan, W.; Sheng, K.; Sanati, M. Comparison of high-solids to liquid anaerobic co-digestion of food waste and green waste. Bioresour. Technol. 2014, 154, 215-221. [CrossRef] [PubMed]

48. Devia, C.R. Biogaz en Vue de son Utilisation en Production D'energie: Séparation des Siloxanes et du Sulfure D’hydrogene. Ph.D. Thesis, Nantes School of Mines, Nantes, France, 2013; pp. 1-202.

49. Timmerberg, S.; Dieckmann, C.; Mackenthun, R.; Kaltschmitt, M. Biomethane in Transportation Sector. In Encyclopedia of Sustainability Science and Technology; Meyers, R.A., Ed.; Springer: New York, NY, USA, 2018.

50. Marchaim, U. Les Procédés de Production de Biogaz Pour le Développement de Technologies Durables; FAO: Rome, Italy, 1994.

51. Wang, H.; Larson, R.A.; Runge, T. Impacts to hydrogen sulfide concentrations in biogas when poplar wood chips, steam treated wood chips, and biochar are added to manure-based anaerobic digestion systems. Bioresour. Technol. Rep. 2019, 7, 100232. [CrossRef]

52. Ali, M.; Hassan, W.; Haj, M.E.; Allagui, A.; Cha, S.W. On the technical challenges affecting the performance of direct internal reforming biogas solid oxide fuel cells. Renew. Sustain. Energy Rev. 2019, 101, 361-375.

53. Wasajja, H.; Lindeboom, R.E.F.; Lier, J.B.V.; Aravind, P.V. Techno-economic review of biogas cleaning technologies for small scale off grid solid oxide fuel cell applications. Fuel Process. Technol. 2020, 197, 106215. [CrossRef]

54. Abd, A.A.; Othman, M.R.; Naji, S.Z.; Hashim, A.S. Methane enrichment in biogas mixture using pressure swing adsorption: Process fundamental and design parameters. Mater. Today Sustain. 2021, 11, 100063. [CrossRef]

55. Atelge, R. Türkiye'de Sı̆̆ır Gübresinden Biyoyakıt Olarak Biyogaz Üretiminin Potansiyeli ve 2030 ve 2053 Y1llarında Karbon Emisyonlarının Azaltılmasına Öngörülen Etkisi. Int. J. Innov. Eng. Appl. 2021, 5, 56-64.

56. Rafiee, A.; Khalilpour, K.R.; Prest, J.; Skryabin, I. Biogas as an energy vector. Biomass and Bioenergy 2021, 144, 105935. [CrossRef]

57. Shen, M.; Zhang, Y.; Hu, D.; Fan, J.; Zeng, G. A review on removal of siloxanes from biogas: With a special focus on volatile methylsiloxanes. Environ. Sci. Pollut. Res. 2018, 25, 30847-30862. [CrossRef]

58. Yang, L.; Ge, X.; Wan, C.; Yu, F.; Li, Y. Progress and perspectives in converting biogas to transportation fuels. Renew. Sustain. Energy Rev. 2014, 40, 1133-1152. [CrossRef]

59. Ghidotti, M.; Fabbri, D.; Torri, C. Determination of linear and cyclic volatile methyl siloxanes in biogas and biomethane by solid-phase microextraction and gas chromatography-mass spectrometry. Talanta 2019, 195, 258-264. [CrossRef]

60. Wang, N.; Tan, L.; Xie, L.; Wang, Y.; Ellis, T. Investigation of volatile methyl siloxanes in biogas and the ambient environment in a landfill. J. Environ. Sci. 2020, 91, 54-61. [CrossRef] [PubMed]

61. Eichler, C.M.A.; Wu, Y.; Cox, S.S.; Klaus, S.; Boardman, G.D. Evaluation of sampling techniques for gas-phase siloxanes in biogas. Biomass Bioenergy 2018, 108, 1-6. [CrossRef]

62. Piechota, G. Removal of siloxanes from biogas upgraded to biomethane by Cryogenic Temperature Condensation System. J. Clean. Prod. 2021, 308, 127404. [CrossRef]

63. Tansel, B.; Surita, S.C. Managing siloxanes in biogas-to-energy facilities: Economic comparison of pre- vs post-combustion practices. Waste Manag. 2019, 96, 121-127. [CrossRef] 
64. Piechota, G. Siloxanes in Biogas: Approaches of Sampling Procedure and GC-MS Method Determination. Molecules 2021, 26, 1953. [CrossRef]

65. Liu, Y.H.; You, Z.; Ji, M.; Wang, Y.; Fei, Y.; Zi, D.; Ma, C. Removal of siloxanes from biogas using acetylated silica gel as adsorbent. Pet. Sci. 2019, 16, 920-928. [CrossRef]

66. Rasi, S.Ã.; Veijanen, A.; Rintala, J. Trace compounds of biogas from different biogas production plants. Energy 2007, 32, 1375-1380. [CrossRef]

67. He, Q.; Tu, T.; Yan, S.; Yang, X.; Duke, M.; Zhang, Y. Relating water vapor transfer to ammonia recovery from biogas slurry by vacuum membrane distillation. Sep. Purif. Technol. 2018, 191, 182-191. [CrossRef]

68. Li, Z.; Wachemo, A.C.; Yuan, H.; Mustafa, R.; Li, X. High levels of ammonia nitrogen for biological biogas upgrading. Int. J. Hydrog. Energy 2020, 45, 28488-28498. [CrossRef]

69. Koonaphapdeelertm, S.; Aggarangsi, P.; Moran, J. Biogas Cleaning and Pretreatment. In Biomethane, Green Energy and Technology; Springer: Singapore, 2020.

70. Porpatham, E.; Ramesh, A.; Nagalingam, B. Experimental studies on the effects of enhancing the concentration of oxygen in the inducted charge of a biogas fuelled spark ignition engine. Energy 2018, 142, 303-312. [CrossRef]

71. Lohmann, H.; Krassowski, J.; Salazar, J.I.G. Determination of volatile organic compounds from biowaste and co- fermentation biogas plants by single-sorbent adsorption. Chemosphere 2016, 153, 48-57.

72. Papadias, D.D.; Ahmed, S.; Kumar, R. Fuel quality issues with biogas energy-An economic analysis for a stationary fuel cell system. Energy 2012, 44, 257-277. [CrossRef]

73. Randazzo, A.; Asensio-ramos, M.; Melián, G.V.; Venturi, S.; Padrón, E.; Hernández, P.A. Volatile organic compounds ( VOCs ) in solid waste land fill cover soil: Chemical and isotopic composition vs. degradation processes. Sci. Total Environ. 2020, 726, 138326. [CrossRef] [PubMed]

74. Mahmoodi, R.; Yari, M.; Ghafouri, J.; Poorghasemi, K. Effect of reformed biogas as a low reactivity fuel on performance and emissions of a RCCI engine with reformed biogas/diesel dual-fuel combustion. Int. J. Hydrog. Energy 2021, 46, 16494-16512. [CrossRef]

75. Ullah, I.; Ha, M.; Othman, D.; Hashim, H.; Matsuura, T.; Ismail, A.F.; Rezaei-dashtarzhandi, M.; Azelee, I.W. Biogas as a renewable energy fuel - A review of biogas upgrading, utilisation and storage. Energy Convers. Manag. 2017, 150, 277-294. [CrossRef]

76. Muñoz, R.; Meier, L.; Diaz, I.; Jeison, D. A review on the state-of-the-art of physical/chemical and biological technologies for biogas upgrading. Rev. Environ. Sci. Bio Technol. 2015, 14, 727-759. [CrossRef]

77. Miltner, M.; Makaruk, A.; Harasek, M. Review on available biogas upgrading technologies and innovations towards advanced solutions. J. Clean. Prod. 2017, 161, 1329-1337. [CrossRef]

78. Niesner, J.; Jecha, D.; Stehlík, P. Biogas upgrading technologies: State of art review in European region. Chem. Eng. Trans. 2013, 35, 517-522.

79. Bauer, F.; Persson, T.; Hulteberg, C.; Tamm, D. Biogas upgrading - technology overview, comparison and perspectives for the future. Biofuels Bioprod. Biorefining 2013, 7, 499-511. [CrossRef]

80. Privalova, E.; Rasi, S.; Mäki-Arvela, P.; Eränen, K.; Rintala, J.; Murzin, D.Y.; Mikkola, J.P. $\mathrm{CO}_{2}$ capture from biogas: Absorbent selection. RSC Adv. 2013, 3, 2979-2994. [CrossRef]

81. Lasocki, J.; Kołodziejczyk, K.; Matuszewska, A. Laboratory-Scale Investigation of Biogas Treatment by Removal of Hydrogen Sulfide and Carbon Dioxide. Pol. J. Environ. Stud. 2015, 24, 1427-1434. [CrossRef]

82. Voice, A.K.; Closmann, F.; Rochelle, G.T. Oxidative Degradation of Amines With High-Temperature Cycling. Energy Procedia 2013, 37, 2118-2132. [CrossRef]

83. Kaya, M.; Atelge, M.R.; Bekirogullari, M.; Eskicioglu, C.; Atabani, A.E.; Kumar, G.; Yildiz, Y.S.; Unalan, S. Carbon molecular sieve production from defatted spent coffee ground using $\mathrm{ZnCl}_{2}$ and benzene for gas purification. Fuel 2020, 277, 118183. [CrossRef]

84. Grande, C.A.; Ribeiro, R.P.L.; Oliveira, E.L.G.; Rodrigues, A.E. Electric swing adsorption as emerging $\mathrm{CO}_{2}$ capture technique. Energy Procedia 2009, 1, 1219-1225. [CrossRef]

85. Mason, J.A.; Sumida, K.; Herm, Z.R.; Krishna, R.; Long, J.R. Evaluating metal-organic frameworks for post-combustion carbon dioxide capture via temperature swing adsorption. Energy Environ. Sci. 2011, 4, 3030-3040. [CrossRef]

86. Yamamoto, T.; Endo, A.; Ohmori, T.; Nakaiwa, M. Porous properties of carbon gel microspheres as adsorbents for gas separation. Carbon 2004, 42, 1671-1676. [CrossRef]

87. Zhao, Q.; Wu, F.; He, Y.; Xiao, P.; Webley, P.A. Impact of operating parameters on $\mathrm{CO}_{2}$ capture using carbon monolith by Electrical Swing Adsorption technology (ESA). Chem. Eng. J. 2017, 327, 441-453. [CrossRef]

88. Scholz, M.; Melin, T.; Wessling, M. Transforming biogas into biomethane using membrane technology. Renew. Sustain. Energy Rev. 2013, 17, 199-212. [CrossRef]

89. Makaruk, A.; Miltner, M.; Harasek, M. Membrane biogas upgrading processes for the production of natural gas substitute. Sep. Purif. Technol. 2010, 74, 83-92. [CrossRef]

90. Haider, S.; Lindbråthen, A.; Hägg, M.-B. Techno-economical evaluation of membrane based biogas upgrading system: A comparison between polymeric membrane and carbon membrane technology. Green Energy Environ. 2016, 1, $222-234$. [CrossRef]

91. Bos, A.; Pünt, I.G.M.; Wessling, M.; Strathmann, H. $\mathrm{CO}_{2}$-induced plasticization phenomena in glassy polymers. J. Membr. Sci. 1999, 155, 67-78. [CrossRef] 
92. Miltner, M.; Makaruk, A.; Harasek, M. Selected Methods of Advanced Biogas Upgrading. Chem. Eng. Trans. 2016, 52, 463-468.

93. Barboiu, C.; Sala, B.; Bec, S.; Pavan, S.; Petit, E.; Colomban, P.; Sanchez, J.; de Perthuis, S.; Hittner, D. Structural and mechanical characterizations of microporous silica-boron membranes for gas separation. J. Membr. Sci. 2009, 326, 514-525. [CrossRef]

94. Andriani, D.; Wresta, A.; Atmaja, T.D.; Saepudin, A. A Review on Optimization Production and Upgrading Biogas Through $\mathrm{CO}_{2}$ Removal Using Various Techniques. Appl. Biochem. Biotechnol. 2014, 172, 1909-1928. [CrossRef] [PubMed]

95. Jürgensen, L.; Ehimen, E.A.; Born, J.; Holm-Nielsen, J.B. Utilization of surplus electricity from wind power for dynamic biogas upgrading: Northern Germany case study. Biomass Bioenergy 2014, 66, 126-132. [CrossRef]

96. Luo, G.; Johansson, S.; Boe, K.; Xie, L.; Zhou, Q.; Angelidaki, I. Simultaneous hydrogen utilization and in situ biogas upgrading in an anaerobic reactor. Biotechnol. Bioeng. 2012, 109, 1088-1094. [CrossRef]

97. Kougias, P.G.; Treu, L.; Benavente, D.P.; Boe, K.; Campanaro, S.; Angelidaki, I. Ex-situ biogas upgrading and enhancement in different reactor systems. Bioresour. Technol. 2017, 225, 429-437. [CrossRef]

98. Luo, G.; Angelidaki, I. Co-digestion of manure and whey for in situ biogas upgrading by the addition of $\mathrm{H}_{2}$ : Process performance and microbial insights. Appl. Microbiol. Biotechnol. 2013, 97, 1373-1381. [CrossRef]

99. Bassani, I.; Kougias, P.G.; Angelidaki, I. In-situ biogas upgrading in thermophilic granular UASB reactor: Key factors affecting the hydrogen mass transfer rate. Bioresour. Technol. 2016, 221, 485-491. [CrossRef]

100. Savvas, S.; Donnelly, J.; Patterson, T.; Chong, Z.S.; Esteves, S.R. Biological methanation of $\mathrm{CO}_{2}$ in a novel biofilm plug-flow reactor: A high rate and low parasitic energy process. Appl. Energy 2017, 202, 238-247. [CrossRef]

101. Meier, L.; Pérez, R.; Azócar, L.; Rivas, M.; Jeison, D. Photosynthetic $\mathrm{CO}_{2}$ uptake by microalgae: An attractive tool for biogas upgrading. Biomass Bioenergy 2015, 73, 102-109. [CrossRef]

102. Mann, G.; Schlegel, M.; Schumann, R.; Sakalauskas, A. Biogas-conditioning with microalgae. Agron. Res. 2009, 7, 33-38.

103. Chi, Z.; O’Fallon, J.V.; Chen, S. Bicarbonate produced from carbon capture for algae culture. Trends Biotechnol. 2011, $29,537-541$. [CrossRef] [PubMed]

104. Xia, A.; Herrmann, C.; Murphy, J.D. How do we optimize third-generation algal biofuels? Biofuels Bioprod. Biorefining 2015, 9, 358-367. [CrossRef]

105. Miltner, M.; Makaruk, A.; Krischan, J.; Harasek, M. Chemical-oxidative scrubbing for the removal of hydrogen sulphide from raw biogas: Potentials and economics. Water Sci. Technol. 2012, 66, 1354-1360. [CrossRef] [PubMed]

106. Petersson, A. Biogas Cleaning; Elsevier: Amsterdam, The Netherlands, 2013; pp. 329-341.

107. Persson, M.; Jonsson, O.; Wellinger, A. Biogas Upgrading To Vehicle Fuel Standards and Grid. IEA Bioenergy 2006, $37,1-32$.

108. Maia, D.S.; Cardozo, F.; Frare, L.; Gimenes, M.; Pereira, N. Purification of biogas for energy use. Chem. Eng. Trans. 2014, 37, 643-648.

109. Petersson, A.; Wellinger, A. Biogas upgrading technologies-developments and innovations. IEA Bioenergy 2009, $20,1-19$.

110. Tippayawong, N.; Thanompongchart, P. Biogas quality upgrade by simultaneous removal of $\mathrm{CO}_{2}$ and $\mathrm{H}_{2} \mathrm{~S}$ in a packed column reactor. Energy 2010, 35, 4531-4535. [CrossRef]

111. Harasimowicz, M.; Orluk, P.; Zakrzewska-Trznadel, G.; Chmielewski, A. Application of polyimide membranes for biogas purification and enrichment. J. Hazard. Mater. 2007, 144, 698-702. [CrossRef]

112. Makaruk, A.; Miltner, M.; Harasek, M. Biogas desulfurization and biogas upgrading using a hybrid membrane system - modeling study. Water Sci. Technol. 2013, 67, 326-332. [CrossRef]

113. Khoshnevisan, B.; Tsapekos, P.; Alvarado-Morales, M.; Rafiee, S.; Tabatabaei, M.; Angelidaki, I. Life cycle assessment of different strategies for energy and nutrient recovery from source sorted organic fraction of household waste. J. Clean. Prod. 2018, 180, 360-374. [CrossRef]

114. Lombardi, L.; Francini, G. Techno-economic and environmental assessment of the main biogas upgrading technologies. Renew. Energy 2020, 156, 440-458. [CrossRef]

115. Allegue, L.B.; Hinge, J.; Allé, K. Biogas and Bio-Syngas Upgrading; Danish Technological Institute: Taastrup, Denmark, 2012; pp. 5-97.

116. Allegue, L.B.; Hinge, J. Biogas Upgrading Evaluation of Methods for $\mathrm{H}_{2} \mathrm{~S}$ Removal; Danish Technological Institute: Taastrup, Denmark, $2014 ;$ p. 31.

117. Montebello, A.M. Aerobic biotrickling filtration for Andrea Monzón Montebello. J. Hazard. Mater 2013, 280, 200-208. [CrossRef] [PubMed]

118. Schweigkofler, M.; Niessner, R. Removal of siloxanes in biogases. J. Hazard. Mater. 2001, 83, 183-196. [CrossRef]

119. Wheless, E.; Pierce, J. Siloxanes in Landfill and Digester Gas Update. In Proceedings of the 27th SWANA Landfill Gas Symposium; Silver Springs: San Antonio, TX, USA, 2004.

120. López, M.E.; Rene, E.R.; Veiga, M.C.; Kennes, C. Biogas Technologies and Cleaning Techniques. In Environmental Chemistry for a Sustainable World: Volume 2: Remediation of Air and Water Pollution; Lichtfouse, E., Schwarzbauer, J., Robert, D., Eds.; Springer: Dordrecht, The Netherlands, 2012; pp. 347-377.

121. Ruiling, G.; Shikun, C.; Zifu, L. Research progress of siloxane removal from biogas. Int. J. Agric. Biol. Eng. 2017, 10, 30-39.

122. Favre, E.; Bounaceur, R.; Roizard, D. Biogas, membranes and carbon dioxide capture. J. Membr. Sci. 2009, 328, 11-14. [CrossRef]

123. Piechota, G. Multi-step biogas quality improving by adsorptive packed column system as application to biomethane upgrading. J. Environ. Chem. Eng. 2021, 9, 105944. [CrossRef] 
124. Guo, X.; Tak, J.K.; Johnson, R.L. Ammonia removal from air stream and biogas by a $\mathrm{H}_{2} \mathrm{SO}_{4}$ impregnated adsorbent originating from waste wood-shavings and biosolids. J. Hazard. Mater. 2009, 166, 372-376.

125. Jiang, X.; Yan, R.; Tay, J.H. Simultaneous autotrophic biodegradation of $\mathrm{H}_{2} \mathrm{~S}$ and $\mathrm{NH}_{3}$ in a biotrickling filter. Chemosphere 2009, 75, 1350-1355. [CrossRef] [PubMed]

126. Malhautier, L.; Gracian, C.; Roux, J.-C.; Fanlo, J.-L.; Le Cloirec, P. Biological treatment process of air loaded with an ammonia and hydrogen sulfide mixture. Chemosphere 2003, 50, 145-153. [CrossRef]

127. Baena-Moreno, F.M.; le Saché, E.; Pastor-Pérez, L.; Reina, T. Membrane-based technologies for biogas upgrading: A review. Environ. Chem. Lett. 2020, 18, 1649-1658. [CrossRef]

128. Norja, J. Value Creation by Automation in Biogas Upgrading. Master's Thesis, Tampere University, Tampere, Finland, 2020.

129. Collet, P.; Flottes, E.; Favre, A.; Raynal, L.; Pierre, H.; Capela, S.; Peregrina, C. Techno-economic and Life Cycle Assessment of methane production via biogas upgrading and power to gas technology. Appl. Energy 2017, 192, 282-295. [CrossRef]

130. Chen, X.Y.; Vinh-Thang, H.; Ramirez, A.A.; Rodrigue, D.; Kaliaguine, S. Membrane gas separation technologies for biogas upgrading. RSC Adv. 2015, 5, 24399-24448. [CrossRef]

131. Sahota, S.; Shah, G.; Ghosh, P.; Kapoor, R.; Sengupta, S.; Singh, P.; Vijay, V.; Sahay, A.; Vijay, V.K.; Thakur, I.S. Review of trends in biogas upgradation technologies and future perspectives. Bioresour. Technol. Rep. 2018, 1, 79-88. [CrossRef]

132. Hosseinipour, S.A.; Mehrpooya, M. Comparison of the biogas upgrading methods as a transportation fuel. Renew. Energy 2019, 130, 641-655. [CrossRef]

133. Singhal, S.; Agarwal, S.; Arora, S.; Sharma, P.; Singhal, N. Upgrading techniques for transformation of biogas to bio-CNG: A review. Int. J. Energy Res. 2017, 41, 1657-1669. [CrossRef]

134. Hahn, H.; Krautkremer, B.; Hartmann, K.; Wachendorf, M. Review of concepts for a demand-driven biogas supply for flexible power generation. Renew. Sustain. Energy Rev. 2014, 29, 383-393. [CrossRef]

135. Harasek, M. Biogas, biomethane and power-to-gas-new options to increase biomethane injection. In Proceedings of the EGATEC2015-European Gas Technology Conference, Vienna, Austria, 25-26 November 2015.

136. Ardolino, F.; Parrillo, F.; Arena, U. Biowaste-to-biomethane or biowaste-to-energy? An LCA study on anaerobic digestion of organic waste. J. Clean. Prod. 2018, 174, 462-476. [CrossRef]

137. Raboni, M.; Urbini, G. Production and use of biogas in Europe: A survey of current status and perspectives. Ambiente E Agua Interdiscip. J. Appl. Sci. 2014, 9, 445-458.

138. Holm-Nielsen, J.B.; Al Seadi, T.; Oleskowicz-Popiel, P. The future of anaerobic digestion and biogas utilization. Bioresour. Technol. 2009, 100, 5478-5484. [CrossRef] [PubMed]

139. O'Connor, S.; Ehimen, E.; Pillai, S.C.; Black, A.; Tormey, D.; Bartlett, J. Biogas production from small-scale anaerobic digestion plants on European farms. Renew. Sustain. Energy Rev. 2021, 139, 110580. [CrossRef]

140. Brémond, U.; Bertrandias, A.; Steyer, J.-P.; Bernet, N.; Carrere, H. A vision of European biogas sector development towards 2030: Trends and challenges. J. Clean. Prod. 2021, 287, 125065. [CrossRef]

141. EPA AgSTAR Data and Trends. Available online: https://www.epa.gov/agstar/agstar-data-and-trends\#adfacts (accessed on 9 July 2021).

142. Hijazi, O.; Munro, S.; Zerhusen, B.; Effenberger, M. Review of life cycle assessment for biogas production in Europe. Renew. Sustain. Energy Rev. 2016, 54, 1291-1300. [CrossRef]

143. Budzianowski, W.M. A review of potential innovations for production, conditioning and utilization of biogas with multiplecriteria assessment. Renew. Sustain. Energy Rev. 2016, 54, 1148-1171. [CrossRef]

144. Krich, K.; Augenstein, D.; Batmale, J.; Benemann, J.; Rutledge, B.; Salour, D. Biomethane from Dairy Waste: A Sourcebook for the Production and use of Renewable Natural Gas in California; USDA Rural Development: Washington, DC, USA, 2005.

145. Kaparaju, P.; Rintala, J. Generation of heat and power from biogas for stationary applications: Boilers, gas engines and turbines, combined heat and power (CHP) plants and fuel cells. In The Biogas Handbook Science, Production and Applications; Elsevier: Amsterdam, The Netherlands, 2013; pp. 404-427.

146. Jatana, G.S.; Himabindu, M.; Thakur, H.S.; Ravikrishna, R.V. Strategies for high efficiency and stability in biogas-fuelled small engines. Exp. Therm. Fluid Sci. 2014, 54, 189-195. [CrossRef]

147. Saxena, S.; Bedoya, I.D. Fundamental phenomena affecting low temperature combustion and HCCI engines, high load limits and strategies for extending these limits. Prog. Energy Combust. Sci. 2013, 39, 457-488. [CrossRef]

148. Reitz, R.D.; Duraisamy, G. Review of high efficiency and clean reactivity controlled compression ignition (RCCI) combustion in internal combustion engines. Prog. Energy Combust. Sci. 2015, 46, 12-71. [CrossRef]

149. Swami Nathan, S.; Mallikarjuna, J.M.; Ramesh, A. An experimental study of the biogas-diesel HCCI mode of engine operation. Energy Convers. Manag. 2010, 51, 1347-1353. [CrossRef]

150. Bedoya, I.D.; Saxena, S.; Cadavid, F.J.; Dibble, R.W.; Wissink, M. Experimental study of biogas combustion in an HCCI engine for power generation with high indicated efficiency and ultra-low NOx emissions. Energy Convers. Manag. 2012, 53, 154-162. [CrossRef]

151. Blizman, B.J.; Makel, D.B.; Mack, J.H.; Dibble, R.W. Landfill Gas Fueled HCCI Demonstration System. In Proceedings of the ASME 2006 Internal Combustion Engine Division Fall Technical Conference, Sacramento, CA, USA, 5-8 November 2006; ASME: New York, NY, USA, 2006; pp. 327-347. 
152. Hosseini, S.E.; Wahid, M.A. Biogas utilization: Experimental investigation on biogas flameless combustion in lab-scale furnace. Energy Convers. Manag. 2013, 74, 426-432. [CrossRef]

153. Kalsi, S.S.; Subramanian, K.A. Effect of simulated biogas on performance, combustion and emissions characteristics of a bio-diesel fueled diesel engine. Renew. Energy 2017, 106, 78-90. [CrossRef]

154. Renzi, M.; Brandoni, C. Study and application of a regenerative Stirling cogeneration device based on biomass combustion. Appl. Therm. Eng. 2014, 67, 341-351. [CrossRef]

155. Mathur, H.B.; Babu, M.K.G.; Prasad, Y.N. A Thermodynamic Simulation Model for a Dual Fuel Open Combustion Chamber Compression Ignition Engine; SAE International: Warrendale, PA, USA, 1986.

156. Prakash, G.; Ramesh, A.; Shaik, A.B. An Approach for Estimation of Ignition Delay in a Dual Fuel Engine. SAE Trans. 1999, 108, 399-405.

157. Mustafi, N.N.; Raine, R.R.; Verhelst, S. Combustion and emissions characteristics of a dual fuel engine operated on alternative gaseous fuels. Fuel 2013, 109, 669-678. [CrossRef]

158. Cacua, K.; Amell, A.; Cadavid, F. Effects of oxygen enriched air on the operation and performance of a diesel-biogas dual fuel engine. Biomass and Bioenergy 2012, 45, 159-167. [CrossRef]

159. Barik, D.; Murugan, S. Investigation on combustion performance and emission characteristics of a DI (direct injection) diesel engine fueled with biogas-diesel in dual fuel mode. Energy 2014, 72, 760-771. [CrossRef]

160. Atelge, R. Kısmi Yük Koşullarında Dizel-Biyogaz Kullanılarak Çift Yakıtlı Dizel Motorun Enerji ve Ekserji Analizi. Eur. J. Sci. Technol. 2021, 27, 334-346.

161. Wang, X.; Qian, Y.; Zhou, Q.; Lu, X. Modulated diesel fuel injection strategy for efficient-clean utilization of low-grade biogas. Appl. Therm. Eng. 2016, 107, 844-852. [CrossRef]

162. Mujtaba, M.A.; Kalam, M.A.; Masjuki, H.H.; Gul, M.; Soudagar, M.E.M.; Ong, H.C.; Ahmed, W.; Atabani, A.E.; Razzaq, L.; Yusoff, M. Comparative study of nanoparticles and alcoholic fuel additives-biodiesel-diesel blend for performance and emission improvements. Fuel 2020, 279, 118434. [CrossRef]

163. Kegl, T.; Kovač Kralj, A.; Kegl, B.; Kegl, M. Nanomaterials as fuel additives in diesel engines: A review of current state, opportunities, and challenges. Prog. Energy Combust. Sci. 2021, 83, 100897. [CrossRef]

164. Feroskhan, M.; Ismail, S.; Gosavi, S.; Tankhiwale, P.; Khan, Y. Optimization of performance and emissions in a biogas-diesel dual fuel engine with cerium oxide nanoparticle addition. Proc. Inst. Mech. Eng. Part D J. Automob. Eng. 2018, 233, 1178-1193. [CrossRef]

165. Feroskhan, M.; Ismail, S.; Kumar, A.; Kumar, V.; Aftab, S.K. Investigation of the effects of biogas flow rate and cerium oxide addition on the performance of a dual fuel CI engine. Biofuels 2017, 8, 197-205. [CrossRef]

166. Barik, D.; Murugan, S.; Samal, S.; Sivaram, N.M. Combined effect of compression ratio and diethyl ether (DEE) port injection on performance and emission characteristics of a DI diesel engine fueled with upgraded biogas (UBG)-biodiesel dual fuel. Fuel 2017, 209, 339-349. [CrossRef]

167. Barik, D.; Murugan, S.; Sivaram, N.M.; Baburaj, E.; Shanmuga Sundaram, P. Experimental investigation on the behavior of a direct injection diesel engine fueled with Karanja methyl ester-biogas dual fuel at different injection timings. Energy 2017, 118, 127-138. [CrossRef]

168. Khayum, N.; Anbarasu, S.; Murugan, S. Combined effect of fuel injecting timing and nozzle opening pressure of a biogas-biodiesel fuelled diesel engine. Fuel 2020, 262, 116505. [CrossRef]

169. Prabhu, A.V.; Avinash, A.; Brindhadevi, K.; Pugazhendhi, A. Performance and emission evaluation of dual fuel CI engine using preheated biogas-air mixture. Sci. Total Environ. 2021, 754, 142389. [CrossRef]

170. Vijin Prabhu, A.; Manimaran, R.; Jeba, P.; Babu, R. Effect of methane enrichment on the performance of a dual fuel CI engine. Int. J. Ambient Energy 2021, 42, 325-330. [CrossRef]

171. Bouguessa, R.; Tarabet, L.; Loubar, K.; Belmrabet, T.; Tazerout, M. Experimental investigation on biogas enrichment with hydrogen for improving the combustion in diesel engine operating under dual fuel mode. Int. J. Hydrog. Energy 2020, 45, 9052-9063. [CrossRef]

172. Bui, V.G.; Bui, T.M.T.; Hoang, A.T.; Nižetić, S.; Nguyen Thi, T.X.; Vo, A.V. Hydrogen-Enriched Biogas Premixed Charge Combustion and Emissions in Direct Injection and Indirect Injection Diesel Dual Fueled Engines: A Comparative Study. J. Energy Resour. Technol. 2021, 143, 1-13. [CrossRef]

173. Hotta, S.K.; Sahoo, N.; Mohanty, K. Comparative assessment of a spark ignition engine fueled with gasoline and raw biogas. Renew. Energy 2019, 134, 1307-1319. [CrossRef]

174. Sadiq Y, R.; Iyer, R.C. Experimental investigations on the influence of compression ratio and piston crown geometry on the performance of biogas fuelled small spark ignition engine. Renew. Energy 2020, 146, 997-1009. [CrossRef]

175. da Costa, R.B.R.; Valle, R.M.; Hernández, J.J.; Malaquias, A.C.T.; Coronado, C.J.R.; Pujatti, F.J.P. Experimental investigation on the potential of biogas/ethanol dual-fuel spark-ignition engine for power generation: Combustion, performance and pollutant emission analysis. Appl. Energy 2020, 261, 114438. [CrossRef]

176. Kim, Y.; Kawahara, N.; Tsuboi, K.; Tomita, E. Combustion characteristics and $\mathrm{NO}_{\mathrm{X}}$ emissions of biogas fuels with various $\mathrm{CO}_{2}$ contents in a micro co-generation spark-ignition engine. Appl. Energy 2016, 182, 539-547. [CrossRef]

177. Kan, X.; Zhou, D.; Yang, W.; Zhai, X.; Wang, C.-H. An investigation on utilization of biogas and syngas produced from biomass waste in premixed spark ignition engine. Appl. Energy 2018, 212, 210-222. [CrossRef] 
178. Hotta, S.K.; Sahoo, N.; Mohanty, K.; Kulkarni, V. Ignition timing and compression ratio as effective means for the improvement in the operating characteristics of a biogas fueled spark ignition engine. Renew. Energy 2020, 150, 854-867. [CrossRef]

179. Hotta, S.K.; Sahoo, N.; Mohanty, K. Ignition advancement study for optimized characteristics of a raw biogas operated spark ignition engine. Int. J. Green Energy 2019, 16, 101-113. [CrossRef]

180. Simsek, S.; Uslu, S. Investigation of the impacts of gasoline, biogas and LPG fuels on engine performance and exhaust emissions in different throttle positions on SI engine. Fuel 2020, 279, 118528. [CrossRef]

181. Bui, V.G.; Tran, V.N.; Hoang, A.T.; Bui, T.M.T.; Vo, A.V. A simulation study on a port-injection SI engine fueled with hydroxyenriched biogas. Energy Sources Part A Recovery Util. Environ. Eff. 2020, 1-17. [CrossRef]

182. Alves, H.J.; Bley Junior, C.; Niklevicz, R.R.; Frigo, E.P.; Frigo, M.S.; Coimbra-Araújo, C.H. Overview of hydrogen production technologies from biogas and the applications in fuel cells. Int. J. Hydrog. Energy 2013, 38, 5215-5225. [CrossRef]

183. Bocci, E.; Di Carlo, A.; McPhail, S.J.; Gallucci, K.; Foscolo, P.U.; Moneti, M.; Villarini, M.; Carlini, M. Biomass to fuel cells state of the art: A review of the most innovative technology solutions. Int. J. Hydrog. Energy 2014, 39, 21876-21895. [CrossRef]

184. Papadam, T.; Goula, G.; Yentekakis, I.V. Long-term operation stability tests of intermediate and high temperature Ni-based anodes' SOFCs directly fueled with simulated biogas mixtures. Int. J. Hydrog. Energy 2012, 37, 16680-16685. [CrossRef]

185. Lackey, J.; Champagne, P.; Peppley, B. Use of wastewater treatment plant biogas for the operation of Solid Oxide Fuel Cells (SOFCs). J. Environ. Manag. 2017, 203, 753-759. [CrossRef] [PubMed]

186. Lanzini, A.; Leone, P.; Guerra, C.; Smeacetto, F.; Brandon, N.P.; Santarelli, M. Durability of anode supported Solid Oxides Fuel Cells (SOFC) under direct dry-reforming of methane. Chem. Eng. J. 2013, 220, 254-263. [CrossRef]

187. Ma, J.; Jiang, C.; Connor, P.A.; Cassidy, M.; Irvine, J.T.S. Highly efficient, coking-resistant SOFCs for energy conversion using biogas fuels. J. Mater. Chem. A 2015, 3, 19068-19076. [CrossRef]

188. Papurello, D.; Borchiellini, R.; Bareschino, P.; Chiodo, V.; Freni, S.; Lanzini, A.; Pepe, F.; Ortigoza, G.A.; Santarelli, M. Performance of a Solid Oxide Fuel Cell short-stack with biogas feeding. Appl. Energy 2014, 125, 254-263. [CrossRef]

189. Shiratori, Y.; Oshima, T.; Sasaki, K. Feasibility of direct-biogas SOFC. Int. J. Hydrog. Energy 2008, 33, 6316-6321. [CrossRef]

190. Janardhanan, V.M. Multi-scale Modeling of Biogas Fueled SOFC. ECS Trans. 2015, 68, 3051-3058. [CrossRef]

191. Ni, M. Modeling and parametric simulations of solid oxide fuel cells with methane carbon dioxide reforming. Energy Convers. Manag. 2013, 70, 116-129. [CrossRef]

192. Tjaden, B.; Gandiglio, M.; Lanzini, A.; Santarelli, M.; Järvinen, M. Small-Scale Biogas-SOFC Plant: Technical Analysis and Assessment of Different Fuel Reforming Options. Energy Fuels 2014, 28, 4216-4232. [CrossRef]

193. Gandiglio, M.; Lanzini, A.; Leone, P.; Santarelli, M.; Borchiellini, R. Thermoeconomic analysis of large solid oxide fuel cell plants: Atmospheric vs. pressurized performance. Energy 2013, 55, 142-155. [CrossRef]

194. Schmersahl, R.; Mumme, J.; Scholz, V. Farm-Based Biogas Production, Processing, and Use in Polymer Electrolyte Membrane (PEM) Fuel Cells. Ind. Eng. Chem. Res. 2007, 46, 8946-8950. [CrossRef]

195. Guan, T.; Alvfors, P.; Lindbergh, G. Investigation of the prospect of energy self-sufficiency and technical performance of an integrated PEMFC (proton exchange membrane fuel cell), dairy farm and biogas plant system. Appl. Energy 2014, 130, 685-691. [CrossRef]

196. Birth, T.; Heineken, W.; He, L. Preliminary design of a small-scale system for the conversion of biogas to electricity by HT-PEM fuel cell. Biomass Bioenergy 2014, 65, 20-27. [CrossRef]

197. Verotti, M.; Servadio, P.; Bergonzoli, S. Biogas upgrading and utilization from ICEs towards stationary molten carbonate fuel cell systems. Int. J. Green Energy 2016, 13, 655-664. [CrossRef]

198. Eichenberger, P.H. The 2 MW Santa Clara Project. J. Power Sources 1998, 71, 95-99. [CrossRef]

199. Trogisch, S.; Hoffmann, J.; Daza Bertrand, L. Operation of molten carbonate fuel cells with different biogas sources: A challenging approach for field trials. J. Power Sources 2005, 145, 632-638. [CrossRef]

200. Ciccoli, R.; Cigolotti, V.; Lo Presti, R.; Massi, E.; McPhail, S.J.; Monteleone, G.; Moreno, A.; Naticchioni, V.; Paoletti, C.; Simonetti, E.; et al. Molten carbonate fuel cells fed with biogas: Combating $\mathrm{H}_{2} \mathrm{~S}$. Waste Manag. 2010, 30, 1018-1024. [CrossRef]

201. Lanzini, A.; Madi, H.; Chiodo, V.; Papurello, D.; Maisano, S.; Santarelli, M.; Van herle, J. Dealing with fuel contaminants in biogas-fed solid oxide fuel cell (SOFC) and molten carbonate fuel cell (MCFC) plants: Degradation of catalytic and electro-catalytic active surfaces and related gas purification methods. Prog. Energy Combust. Sci. 2017, 61, 150-188. [CrossRef]

202. Månsson, A.; Sanches-Pereira, A.; Hermann, S. Biofuels for road transport: Analysing evolving supply chains in Sweden from an energy security perspective. Appl. Energy 2014, 123, 349-357. [CrossRef]

203. Olsson, L.; Fallde, M. Waste(d) potential: A socio-technical analysis of biogas production and use in Sweden. J. Clean. Prod. 2015, 98, 107-115. [CrossRef]

204. Monnerie, N.; Roeb, M.; Houaijia, A.; Sattler, C. Coupling of Wind Energy and Biogas with a High Temperature Steam Electrolyser for Hydrogen and Methane Production. Green Sustain. Chem. 2014, 4, 60-69. [CrossRef]

205. Kharton, V.V.; Yaremchenko, A.A.; Valente, A.A.; Sobyanin, V.A.; Belyaev, V.D.; Semin, G.L.; Veniaminov, S.A.; Tsipis, E.V.; Shaula, A.L.; Frade, J.R.; et al. Methane oxidation over Fe-, Co-, Ni- and V-containing mixed conductors. Solid State Ion. 2005, 176, 781-791. [CrossRef]

206. Yang, S.; Kondo, J.N.; Hayashi, K.; Hirano, M.; Domen, K.; Hosono, H. Partial oxidation of methane to syngas over promoted C12A7. Appl. Catal. A Gen. 2004, 277, 239-246. [CrossRef] 
207. Tu, X.; Whitehead, J.C. Plasma dry reforming of methane in an atmospheric pressure AC gliding arc discharge: Co-generation of syngas and carbon nanomaterials. Int. J. Hydrog. Energy 2014, 39, 9658-9669. [CrossRef]

208. Izquierdo, U.; Barrio, V.L.; Requies, J.; Cambra, J.F.; Güemez, M.B.; Arias, P.L. Tri-reforming: A new biogas process for synthesis gas and hydrogen production. Int. J. Hydrog. Energy 2013, 38, 7623-7631. [CrossRef]

209. IRENA. Production of Bio-Methanol Technology Brief; IRENA: Masdar City, Abu Dhabi, United Arab Emirates, 2013; pp. 1-28.

210. Park, D.; Lee, J. Biological conversion of methane to methanol. Korean J. Chem. Eng. 2013, 30, 977-987. [CrossRef]

211. Shamsul, N.S.; Kamarudin, S.K.; Rahman, N.A.; Kofli, N.T. An overview on the production of bio-methanol as potential renewable energy. Renew. Sustain. Energy Rev. 2014, 33, 578-588. [CrossRef]

212. Su, Z.; Ge, X.; Zhang, W.; Wang, L.; Yu, Z.; Li, Y. Methanol Production from Biogas with a Thermotolerant Methanotrophic Consortium Isolated from an Anaerobic Digestion System. Energy Fuels 2017, 31, 2970-2975. [CrossRef]

213. Munasinghe, P.C.; Khanal, S.K. Biomass-derived syngas fermentation into biofuels: Opportunities and challenges. Bioresour. Technol. 2010, 101, 5013-5022. [CrossRef] [PubMed] 